\title{
AVALIAÇÃO DA RESISTÊNCIA À FRATURA DE DENTES \\ TRATADOS ENDODONTICAMENTE RECONSTRUÍDOS COM \\ PINOS DENTÁRIOS E COM PINOS DE FIBRAS DE POLIETILENO
}

OSVALDO BAZZAN KAIZER

Dissertação apresentada à Faculdade de

Odontologia de Bauru, da Universidade de

São Paulo, como parte dos requisitos para obtenção do título de Mestre em Odontologia, área de Reabilitação Oral.

Bauru

2003 


\section{AVALIAÇÃO DA RESISTÊNCIA À FRATURA DE DENTES \\ TRATADOS ENDODONTICAMENTE RECONSTRUIIDOS COM \\ PINOS DENTÁRIOS E COM PINOS DE FIBRAS DE POLIETILENO}

OSVALDO BAZZAN KAIZER

Dissertação apresentada à Faculdade de

Odontologia de Bauru, da Universidade de

São Paulo, como parte dos requisitos para obtenção do título de Mestre em Odontologia, área de Reabilitação Oral.

Orientador: Prof. Dr. Gerson Bonfante

Bauru

2003 


\section{Kaizer, Osvaldo Bazzan}

K123a Avaliação da resistência à fratura de dentes tratados endodonticamente reconstruídos com pinos dentários e com pinos de fibras de polietileno / Osvaldo Bazzan Kaizer. - Bauru, 2003.

xv, 142 p. + apênd. : il. ; 30 cm.

Dissertação (Mestrado) - - Faculdade de Odontologia de Bauru. Universidade de São Paulo.

Orientador: Prof. Dr. Gerson Bonfante

Autorizo, exclusivamente para fins acadêmicos e científicos, a reprodução total ou parcial desta dissertação, por processos fotocopiadores e outros meios eletrônicos.

Assinatura:

Data de aprovação pelo Comitê de Ética da FOB/USP: 26-04-2001

Número de protocolo: inexistente em 2001 
18 de fevereiro de 1973

Tupanciretã - RS

Nascimento

Filiação

Olavo Kaizer

Maria Lúcia Jaeger Bazzan Kaizer

1990-1994

Curso de Graduação em Odontologia pela

Universidade Federal de Santa Maria - RS

1998-1999

Curso de Especialização em Prótese

Dentária pela Universidade Luterana do

Brasil - RS

1998

Professor Auxiliar de Prótese Dentária da Universidade Federal de Santa Maria - RS

2001-2003

Curso de Pós-Graduação - Mestrado em

Reabilitação Oral, pela Faculdade de

Odontologia de Bauru - USP - SP

Associações

Conselho Regional de Odontologia Seção do Rio Grande do Sul 
"O conhecimento nunca nos é dado de graça;

Temos de encontrá-lo sozinhos, Depois de realizar uma jornada Que ninguém pode fazer por nós Ou nos poupar de fazer."

Marcel Proust 


\section{Dedico este trabalho}

À minha querida mãe Maria Lúcia, que além de me conceder a maior das dádivas - a própria existência, presenteia-me com a benção de seu amor irrestrito e me acompanha tão próxima quanto possivel em todos os instantes.

Ao men estimado pai Olavo, cujos exemplos de vida, cuja sabedoria e cuja integridade em tudo que realiza moldaram-me como sou, realmente agradeço por sempre me direcionar no caminho correto.

À minha amada esposa Rosane, agradeco por seu carinho $e$ compreensão, pelo constante incentivo e apoio incondicional, que têm sido de fundamental importância nos momentos dificicis.

À minha irmã e grande amiga Cristina, cuja inteligência inerente, personalidade forte e alegria de viver me servem de inspiração para continuar a buscar meus objetivos.

A Deus, pois a consciência de Sua presença invisivel ao meu lado é uma motivação permanente. 
Ao men orientador, Prof. Dr. Gerson Bonfante , agradeço por compartilhar comigo sua experiência inestimável e sua inteligência aguda, bem como por sua paciência inesgotável.

Que fique aqui registrada minha eterna gratidão por sua assistência sempre que dela necessitei, por suas palavras e atitudes sempre serenas e seguras e, finalmente, pelas lições de vida que me foram transmitidas juntamente om seu conbecimento científico. 


\title{
Agradecimentos $E_{\text {speciais }}$
}

\begin{abstract}
À Faculdade de Odontologia de Santa Maria, representada por sen Coordenador Prof. Dr. Paulo Afonso Burmann, por sua dedicação para com a Faculdade e por sua firmeza de propósitos.
\end{abstract}

Ao Chefe do Departamento de Odontologia Restauradora da Faculdade de Odontologia de Santa Maria, Prof. Dr. Roberto Bisogno, pelo sen inestimável apoio, pelo respeito com que sempre me tratou e, acima de tudo, por sua valiosa amizade.

Ao Prof. Dr. Luiz Fernando Pegoraro, por sua permanente e incansável busca em melhorar a qualidade de nosso aprendizado durante todo o curso de Mestrado e por ser um exemplo de Mestre e cientista.

Ao Prof. Dr. Acácio Lins do Valle, pela sua incessante preocupação com nosso bem-estar, pelo oferecimento de auxilio antes mesmo que fosse necessário solicitá-lo e pela humanidade que sempre demonstrou para comigo - algo raro em nossos dias. 
A todos os professores da Faculdade de Odontologia de Santa Maria, especialmente à Prof. Dra Amália Cáceres Moncada, Prof. Dr. Henrique Hollweg, Prof. Dr Leticia Jacques, Prof. Dr. Clándio Figueiró, Prof. Dr ${ }^{a}$ Lúcia Helena Mozzaquatro, Prof. Dr. Daltro Antunes Dutra, Prof. Dr. Paulo Afonso Burmann, Prof. Dra Kátia Olmedo Braum, Prof. Paulo Antônio Pimenta e Prof. Luiz. Felipe Soares, por sua amizade e pelo voto de confiança em mim depositado.

À Prof. Dr. Amália Cáceres Moncada e ao Prof. Dr. Gustavo Quesada agradeço por terem sido os primeiros a acreditarem em mim, concedendo-me uma oportunidade, por tudo aquilo que tão pacientemente me ensinaram e ainda por dedicarem-se verdadeiramente à tudo aquilo que fazem.

Ao Prof. Dr. Ney Mugica Mutti dedico um agradecimento especial por sua assistência abnegada e altruista em momentos decisivos de minha vida, bem como por seus sempre sábios e oportunos conselhos.

A todos meus Professores na Faculdade de Odontologia de Bauru, especialmente ao Prof. Dr. Carlos Araújo, ao Prof. Dr. Paulo César Conti, ao Prof. Dr. Milton Salvador, ao Prof. Dr. Paulo Martins, ao Prof. Dr. José Henrique Rubo, ao Prof. Dr. Wellington Bonachella e ao Prof. Dr. Renato de Freitas, pelo empenho e dedicaşão em transmitir da mais perfeita e completa forma possivel seus amplos conhecimentos.

Ao meu colega Mauro Antônio da Cruz, pela amizade com que me brindou desde o inicio do curso, por partilhar sua preciosa experiência comigo e por todas as conversas que tivemos tanto nos momentos alegres como naqueles mais penosos. 
Aos meu colegas Paulo, Tatiany, Leylha, Stella, Renato, Rafael, Jefferson, Mariana, Luiz Gustavo e Luciana, por compartilharem seus conhecimentos comigo quando aqui cheguei, por sua consciência de coleguismo e por seu espirito de união que só merecem elogios, sem exceşão.

Aos Doutorandos Anuar, Carlos, Nelson, William, Juliano, Vinícius, Rudys, Gildo e Stefania, que sempre me trataram de igual para igual, nunca recusando auxilio ou informacōes quando deles necessitei.

Aos técnicos de laboratório Reivanildo e Marcelo, os quais dividiram, da mesma forma, seus conbecimentos comigo, e pela disponibilidade na confecção de material para esta tese e de trabalhos para os pacientes atendidos nas clínicas.

Aos funcionários das clínicas, especiamente à Senhora Ana Maria, à Senhora Cleusa, à Luzৃia e à Valquiria, pelo carinho e dedicação que tornavam mais agradáveis as aulas nas clinicas.

Às funcionárias do Departamento de Prótese Edna, Cláudia e Débora, bem como a todos os funcionários da biblioteca, especialmente à Cybelle, $V$ aléria e César, que sempre mostraram extraordinária disponibilidade e eficiência à menor solicitação, fazendo jus ao bom nome da Faculdade de Odontologia de Bauru, da Universidade de São Paulo. 


\title{
Agradecimentos
}

\begin{abstract}
À Faculdade de Odontologia de Bauru - Universidade de São Paulo, representada por sua diretora Prof. Dr. Maria Fidela de Lima Navarro, pela oportunidade da realização de meu curso de Mestrado nesta conceituada escola.
\end{abstract}

Ao Presidente da Comissão de Pós-Graduação, Prof. Dr. José Carlos Pereira, pelo seu constante empenho e interesse em buscar a melhoria das condições da Pós-Graduação.

Ao Prof. Dr. José Roberto Lauris, pela orientação na confecção da análise estatística do presente estudo.

Aos funcionários da Pós-Graduação, especialmente à Giane e ao Aurélio, pela pronta atenção dispensada.

Aos meus pacientes, a maioria dos quais, além de permitir a aplicação prática dos conbecimentos cientificos, tornaram-se também meus amigos.

A todas as pessoas que de alguma forma contribuiram, direta ou indiretamente, para a conclusão deste trabalho. 


\section{SUMÁRIO}

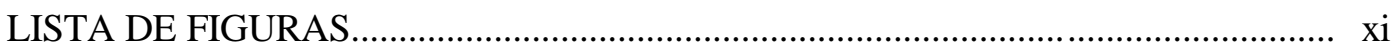

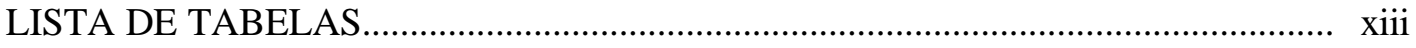

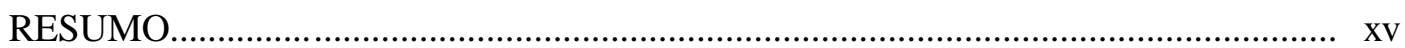

1 INTRODUÇÃO

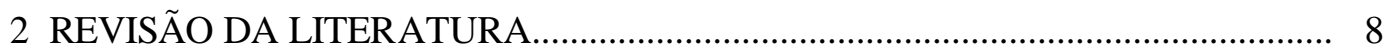

3 PROPOSIÇÃO

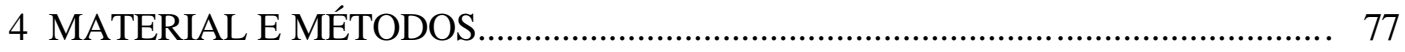

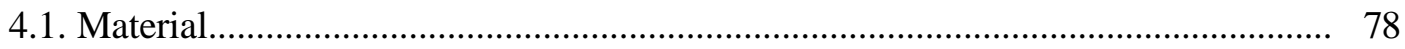

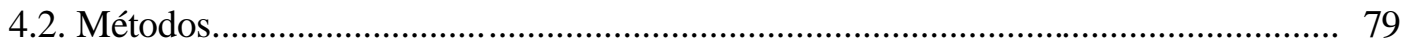

4.2.1. Seleção dos dentes...................................................................................... 80

4.2.2. Preparo dos corpos de prova........................................................................... 82

4.2.2.1 Procedimentos prévios................................................................................ 82

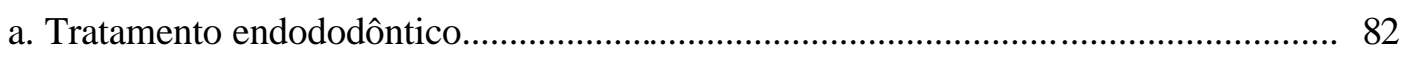

b. Secção da porção coronária.................................................................................. 82

c. Fixação das raízes em cilindros plásticos.................................................................... 83

4.2.2.2. Preparo dos corpos de prova do grupo 1........................................................ 83

4.2.2.3. Preparo dos corpos de prova do grupo 2 ........................................................... 88

4.2.2.4. Preparo dos corpos de prova do grupo 3 ........................................................... 90

4.2.2.5. Preparo dos corpos de prova do grupo 4 .......................................................... 95

4.2.2.6. Teste de resistência à fratura............................................................................ 96

4.2.2.7. Registro do limiar de falha....................................................................... 98

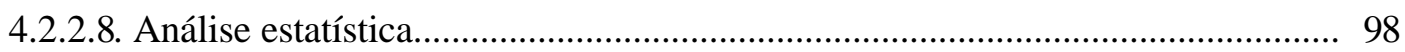

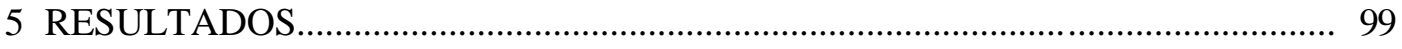

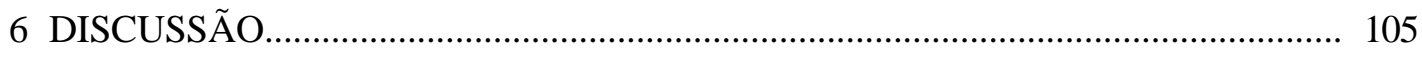

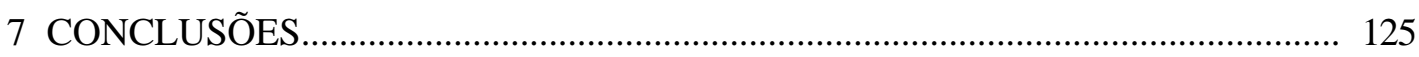

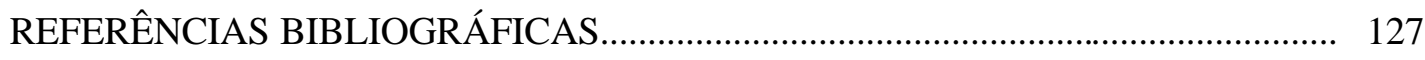

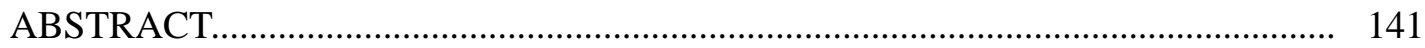

APÊNDICE 


\section{LISTA DE FIGURAS}

FIGURA 2.4- Quadro comparativo das características mais relevantes das principais fibras de polietileno atualmente comercializadas (BOTTINO et al., 2001)

FIGURA 4.1 - Material utilizado na pesquisa

FIGURA 4.2 - Representação esquemática dos quatro grupos experimentais...............................................................

FIGURA 4.3- Representação esquemática dos preparos intra-radiculares executados em cada grupo experimental....................................

FIGURA 4.4- Vista incisal do preparo dos condutos nos quatro grupos experimentais

FIGURA 4.5A- Confecção de núcleo à base de fibras de polietileno - fitas de Ribbond emergindo do conduto.

FIGURA 4.5B- Confecção de núcleo à base de fibras de polietileno - utilização de pinça hemostática para conformação do pino de fibras de polietileno.

FIGURA 4.5C - Confecção de núcleo à base de fibras de polietileno - pino de fibras de polietileno após polimerização do cimento resinoso....

FIGURA 4.6A- Núcleo à base de fibras de polietileno - vista frontal.................. 87

FIGURA 4.6B- Núcleo à base de fibras de polietileno - vista lateral.................. 88

FIGURA 4.7 - $\quad$ Pino dentário do grupo 2 2.................................................... 89

FIGURA 4.8- $\quad$ Pino dentário sendo submetido à aplicação de carga na prensa estática.

FIGURA 4.9- Desenho do pino dentário após a utilização do padrão de resina acrílica 


\begin{tabular}{|c|c|c|}
\hline FIGURA 4.10- & $\begin{array}{l}\text { Matrizes de silicona de condensação confeccionadas a partir } \\
\text { do padrão de resina acrílica, para auxiliar a conferir o desgaste }\end{array}$ & 92 \\
\hline FIGURA 4.11- & 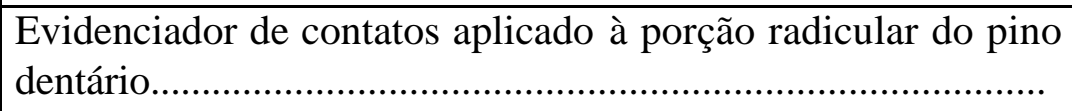 & 93 \\
\hline FIGURA 4.12- & 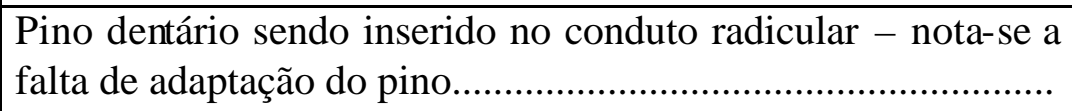 & 93 \\
\hline FIGURA 4.13- & 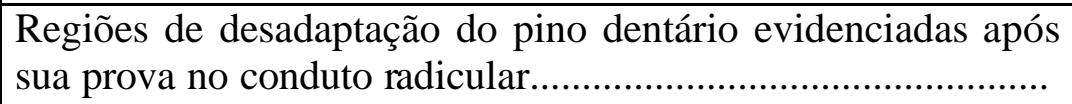 & 94 \\
\hline FIGURA 4.14- & 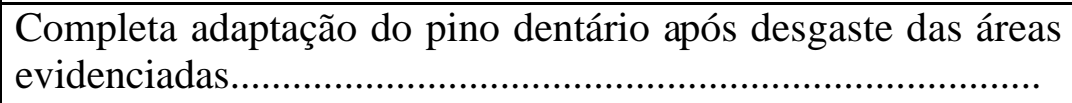 & 94 \\
\hline FIGURA 4.15- & Preparo da porção radicular de pino dentário do grupo & 96 \\
\hline FIGURA 4.16- & $\begin{array}{l}\text { Carregamento de compressão formando um ângulo de } 45^{\circ} \text { em } \\
\text { relação ao plano horizontal }\left(135^{\circ} \text { em relação ao longo eixo do }\right. \\
\text { dente) }\end{array}$ & 97 \\
\hline FIGURA 5.1 - & 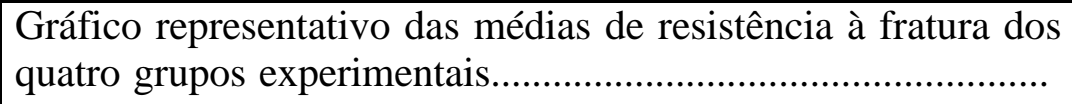 & 101 \\
\hline FIGURA 5.2- & 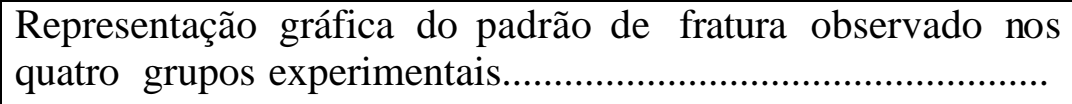 & 103 \\
\hline FIGURA 6.1 - & 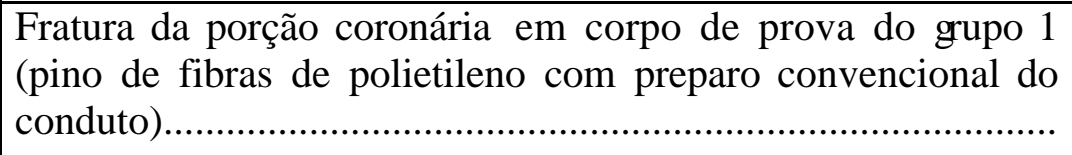 & 119 \\
\hline FIGURA 6.2- & 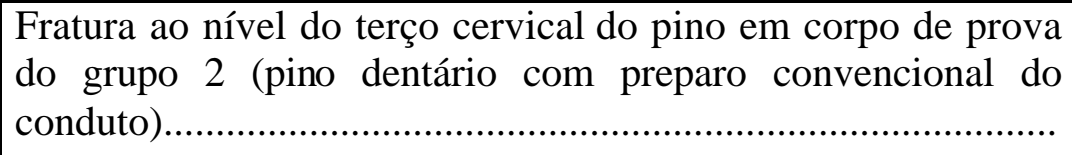 & 120 \\
\hline FIGURA 6.3- & 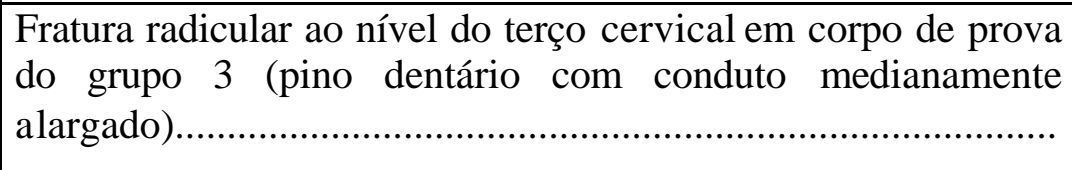 & 120 \\
\hline FIGURA 6.4- & $\begin{array}{l}\text { Fratura radicular ao nível do terço cervical em corpo de prova } \\
\text { do grupo } 4 \text { (pino dentário com conduto amplamente alargado) }\end{array}$ & 121 \\
\hline
\end{tabular}




\section{LISTA DE TABELAS}

TABELA 2.1- Valores de resistência à fratura e padrões de falha para dentes tratados endodonticamente restaurados com fibras de polietileno (KARNA, 1996)

TABELA 2.2- Resistência à flexão até o limite elástico, resistência à flexão máxima e módulo de flexão de quatro fibras comerciais (GOLDBERG et al., 1998)

TABELA 2.3- Médias de resistência à fratura e desvios padrão para cada grupo experimental (SIRIMAI; RIIS; MORGANO, 1999)..........

TABELA 5.1- Valores individuais de resistência à fratura (em kgf) para cada corpo de prova, médias e respectivos desvios padrão para cada grupo experimental.

TABELA 5.2- Médias de resistência à fratura e respectivos desvios padrão em cada grupo experimental.

TABELA 5.3- Resultados da Análise de Variância a um critério (ANOVA) para o ensaio de resistência à fratura das raízes.

TABELA 5.4- Teste de TUKEY para comparações múltiplas 102

TABELA 5.5- Padrão de fratura observado para cada grupo experimental... 


\section{RESUMO}

Avalioutse a resistência à fratura de dentes tratados endodonticamente reconstruídos com pinos de fibras de polietileno e com pinos dentários. Para tal, selecionaram-se 60 caninos superiores humanos seccionados na junção cementoesmalte, tratados endodonticamente (condutos desobturados até a profundidade de $8 \mathrm{~mm}$ ) e fixados em blocos de resina acrílica. Distribuíram-se os corpos de prova aleatoriamente em quatro grupos de 15 unidades: 1) preparo convencional dos condutos e confecção de pinos de fibras de polietileno; 2) preparo convencional dos condutos e pinos dentários; 3) condutos medianamente alargados e pinos dentários; 4) condutos amplamente alargados e pinos dentários. Nos grupos 1 e 2 , dilataram-se os condutos até a broca Largo de número 4; nos grupos 3 e 4, os condutos sofreram desgastes seqüenciais padronizados, simulando raízes medianamente ou amplamente destruídas. No grupo 4, a espessura das paredes do conduto no terço cervical era de 0,5mm. Realizoutse a cimentação dos pinos com sistema adesivo Scotchbond MultiUso Plus e cimento resinoso Enforce. Construiu-se a porção coronária dos núcleos com resina composta autopolimerizável reforçada com titânio Ti-Core. Armazenaram-se os espécimes por 24 horas em água destilada, submetendo-os então aos testes de resistência à fratura sob compressão na máquina de ensaios universal Kratos, até falha do sistema. A força de compressão foi de $100 \mathrm{kgf}$ e a velocidade de $0,5 \mathrm{~mm} / \mathrm{min}$, sendo aplicada em ângulo de $135^{\circ}$ em relação ao longo eixo da raiz. Os valores de resistência à fratura encontrados foram, em ordem decrescente: Grupo 3 58,67kgf; Grupo 2 - 53,30kgf; Grupo 4 - 47,91kgf; Grupo 1 - 45,46kgf, sendo que a análise estatística (ANOVA e Tukey) demonstrou diferença estatisticamente significante somente entre os grupos 1 e 3. Em relação ao padrão de fratura, observoutse: Grupo 1 - ampla predominância de fratura da porção coronária do núcleo; Grupo 2 e Grupo 3 - padrão variado de fraturas (tanto radiculares como do pino e/ou porção coronária); Grupo 4 - todas as raízes fraturaram. 


\section{INTRODUÇÃO}

Embora o princípio primordial da Odontologia seja a preservação do sistema estomatognático, procurando prevenir o desenvolvimento de qualquer tipo de patologia, existem situações em que tais alterações já estão instaladas. Nestes casos, deve-se utilizar conhecimentos científicos bem estabelecidos e um atendimento integrado que permitam restabelecer uma situação de saúde e normalidade. Um dos desafios da Odontologia Restauradora é a adequada reconstrução dos dentes endodonticamente tratados, devido ao fato de que muitas vezes toda ou a maior parte de sua estrutura coronária foi perdida por cárie, erosão, abrasão, restaurações anteriores, traumas e mesmo pelo próprio acesso para o tratamento endodôntico $84,105,121$

Nestes casos, está geralmente indicado um núcleo intra-radicular, que deveria idealmente promover suficiente retenção à restauração e ainda reforçar a estrutura dentária remanescente ${ }^{23,84}$. Se metade ou mais da estrutura coronária foi perdida, um pino geralmente é necessário para suportar a coroa ${ }^{105,64}$. Pesquisas recentes demonstraram que os sistemas convencionais de núcleos não reforçam a estrutura dentária remanescente, podendo na verdade torná-la mais susceptível à fratura $^{28,48,106,127}$. Atualmente há uma tendência no sentido de não se utilizar núcleos em todos os dentes tratados endodonticamente, mas somente naqueles casos onde forem necessários para forne cer retenção à restauração coronária ${ }^{114,120}$.

Com o surgimento da técnica de condicionamento ácido do esmalte ${ }^{17}$, aliada ao desenvolvimento das resinas compostas ${ }^{15}$ e posteriormente do ionômero de vidro $^{131}$, houve grandes avanços nas técnicas restauradoras, que se tornaram mais eficazes e conservadoras.

A busca por sistemas de núcleos intra-radiculares mais estéticos e com capacidade real de reforçar a estrutura dentária impulsionou a pesquisa de núcleos não-metálicos. Um objetivo muito almejado é o da restauração em monobloco, isto é, a obtenção de um único complexo biomecânico pela adesão entre estruturas dentárias e materiais de reforço (pino, agente cimentante e material de preenchimento 
coronário) e pela utilização de materiais com propriedades mecânicas semelhantes às da estrutura dentária remanescente ${ }^{30,31}$. Pinos não-metálicos à base de compósitos reforçados com fibras associam um elemento de alta resistência (fibras de carbono, fibras de polietileno, fibras de vidro ou fibras de quartzo) com matrizes resinosas (geralmente epóxicas) $^{40,41}$.

FREILICH et al. ${ }^{40}$, em 2000 e FELIPPE et al. ${ }^{37}$, em 2001, ressaltaram que compósitos reforçados com fibras (especialmente fibras de vidro e fibras de carbono) estão hoje rotineiramente substituindo metais em número crescente de aplicações na engenharia civil, indústria naval, aeroespacial, automobilística e esportiva. Tais materiais possuem alta resistência, propriedades não-corrosivas, potencial de translucidez, adequadas propriedades adesivas e facilidade de reparo em relação aos metais.

Recentemente, fibras de polietileno têm sido preconizadas para confecção de núcleos intra-radiculares ${ }^{41,62,64,82,107,113}$. As mais indicadas são aquelas que possuem sua superfície tratada por plasma de gás frio para possibilitar união química à estrutura dentária e à matriz orgânica da resina composta, bem como uma arquitetura entrelaçada, para permitir reforço multidirecional da resina e propiciar melhor distribuição do estresse ${ }^{41,82,101}$.

Em 1996, KARNA ${ }^{62}$ verificou a possibilidade de confecção de núcleos intra-radiculares com fibras de polietileno entrelaçadas Ribbond. Nos testes clínicos, mais de 130 dentes receberam núcleos de Ribbond, havendo somente dois casos de fratura de raiz (as quais possuíam paredes radiculares com menos de $1 \mathrm{~mm}$ de espessura) e três casos de fratura da resina composta da porção coronária. Os testes laboratoriais demonstraram que as forças necessárias para fraturar os espécimes foram normalmente maiores que aquelas geradas intra-oralmente. As principais vantagens desses núcleos seriam: 1) Conservação da estrutura dentária como o núcleo adere ao conduto radicular, este não precisa ser adicionalmente alargado; 2) Morfológica - o preenchimento do conduto tão completamente quanto possível, aliado à adesão do pino às irregularidades e reentrâncias torna-o retentivo e não-rotacional; 3) Flexibilidade das fibras compatível com a flexibilidade da raiz minimiza propagação de microfraturas radiculares; 4) Memória elástica mínima das 
fibras - facilita a inserção no conduto; 5) Estética - cor similar à do dente e ausência de corrosão; 6) Fácil remoção - risco mínimo à estrutura dentária. A técnica tem sido indicada em casos de condutos alargados, nos quais núcleos metálicos fundidos ou pré-fabricados possuem prognóstico desfavorável ${ }^{54}$.

SIRIMAI; RIIS; MORGANO ${ }^{112}$, em 1999, avaliaram a resistência à fratura e incidência de fratura vertical de raízes despolpadas com seis diferentes sistemas de núcleos. Demonstraram que núcleos de preenchimento confeccionados unicamente com fibras de polietileno Ribbond e resina composta possuem resistência à fratura menor que a dos sistemas de núcleos metálicos fundidos ou pinos metálicos pré-fabricados, porém clinicamente suficiente; por outro lado, possuem uma incidência de fraturas radiculares significantemente menor que aquela ocorrida com núcleos metálicos fundidos ou pinos pré-fabricados metálicos. Além disso, a utilização de pinos pré-fabricados de diâmetros menores que o do conduto, envolvidos por Ribbond e resina composta, exibiu resistência à fratura clinicamente aceitável e menos fraturas radiculares que núcleos metálicos fundidos.

Várias pesquisas comprovaram que fibras de polietileno, especialmente se tratadas com plasma, são capazes de reforçar resina acrílica convencional, resina acrílica modificada ou resina composta, aumentando sua resistência à fratura ${ }^{16,26,27,47,67,69,95,102,122,130}$.

Também tem sido aventada a possibilidade de utilização de pinos confeccionados a partir de dentes naturais ${ }^{11,12,24,55,94,134}$, os quais são denominados núcleos biológicos ou pinos dentários ${ }^{24,55}$. As vantagens destes pinos são: 1) excelente estética; 2) propriedades similares às da estrutura dental perdida, o que nenhum material conseguiu ainda reproduzir totalmente; 3) total biocompatibilidade; 4) adaptação à configuração do conduto, favorecendo maior resistência do dente e melhor retenção do pino, em relação aos pinos pré-fabricados; 5) resiliência comparável a do dente; 6) excelente adesão à estrutura dental e à resina composta; 7) confecção em sessão única (opcional) ${ }^{11,55}$.

BONILLA $^{12}$, em 2001, demonstrou que a resistência à fratura de raízes amplamente destruídas e reconstruídas com sistemas adesivos e pinos 
dentários equivale à resistência de dentes com preparo convencional do cond uto e restaurados com núcleo metálico fundido; além disso, sua resistência é 30\% maior do que aquela de dentes com conduto amplamente destruído e restaurados com núcleo metálico fundido ou reconstruídos morfologicamente com resina composta e restaurados com núcleo metálico fundido. Assim, a principal aplicação dos pinos dentários pode vir a ser a reconstituição de raízes com diferentes graus de perda dentinária interna.

Fragmentos dentários autógenos e heterógenos vêm sendo utilizados desde os anos 70 para restauração de dentes fraturados ou destruídos por cárie. ESBERARD; SILVA FILHO; GABRIELLI ${ }^{33}$, em 1978, publicaram relato pioneiro de colagem do fragmento de dente anterior. Inúmeros outros autores descreveram procedimentos semelhantes ${ }^{8,9,61,74,110,111}$. GABRIELLI et al. ${ }^{42}$, em 1981, foram os primeiros a utilizar fragmentos de dentes extraídos para restaurar dentes anteriores fraturados. Outros pesquisadores demonstraram a validade da técnica ${ }^{19,20,108}$. KONZEN; BUSATO ${ }^{66}$, em 1990, descreveram o primeiro caso de colagem de fragmento de dente extraído em dentes posteriores, após o qual seguiram-se outros $^{57,71,96,132}$. Os autores salientaram que ainda não foi desenvolvido um material restaurador que supere as propriedades da estrutura dentária.

A maioria dos métodos utilizados para aumentar a retenção dos núcleos enfraquece consideravelmente a estrutura radicular já comprometida, aumentando a tendência da raiz à fratura ${ }^{64}$. Alargamento excessivo do conduto para inserção de pinos de grande diâmetro debilita a raiz e pode resultar em fratura radicular sob cargas funcionais. A necessidade de preservar a estrutura remanescente para máxima resistência da raiz é tão importante quanto a retenção. Devido ao fato de que a resistência à fratura da raiz está diretamente relacionada com o volume de dentina remanescente ${ }^{83,117,124}$, o conduto deve ser alargado somente o suficiente para ser capaz de reter o núcleo e proporcionar ao mesmo resistência suficiente. TRABERT; CAPUTO; ABOU-RASS ${ }^{25}$, em 1978, demonstraram que raízes reforçadas com pinos de menor diâmetro possuem maior resistência à fratura que quando utilizados pinos mais largos. CAPUTO; STANDLEE ${ }^{23}$, em 1976, 
propuseram que pelo menos $1 \mathrm{~mm}$ de dentina sadia deveria ser mantido em toda a circunferência do conduto.

Técnicas restauradoras com núcleos tornam-se dificultadas ou mesmo inviáveis quando a raiz exibe amplo alargamento devido a um extenso envolvimento por lesões cariosas, restauração prévia com núcleos de tamanho excessivo, causas iatrogênicas (acesso para tratamento endodôntico, superinstrumentação), desenvolvimento incompleto, reabsorção interna ou anomalias de desenvolvimento (fusão). Em canais alargados, núcleos metálicos fundidos produziriam um efeito de cunha; pinos pré-fabricados possuem normalmente adaptação imprecisa nesses casos, obrigando o operador a utilizar quantidades excessivas de cimento para substituir a estrutura perdida ${ }^{54}$. Se não forem reforçadas, raízes com paredes muito finas estarão altamente sujeitas à fratura durante cimentação dos pinos ou função subseqüente. Por estas razões, raízes debilitadas têm sido rotineiramente condenadas à extração $^{63,93,72,73,104}$.

Em dentes com perda prévia de significantes quantidades de estrutura dentária coronal e radicular, torna-se crítico buscar alternativas aos sistemas convencionais de núcleos. A substituição e reforço da estrutura intra-radicular com um material elasticamente compatível com a dentina é mais segura que a substituição da estrutura intra-radicular destruída com núcleos metálicos fundidos, os quais possuem alto módulo de elasticidade, com potencial para transferir o estresse à estrutura dentinária circundante comprometida ${ }^{104}$. Pinos com módulo de elasticidade mais baixo e próximo ao do remanescente dentário distribuem mais eqüitativamente o estresse à estrutura remanescente ${ }^{40,104}$. Além disso, o sistema utilizado deve proteger a raiz de fraturas dentárias. Uma das técnicas propostas para reforçar raízes enfraquecidas e que vem sendo bastante aceita é o reforço das raízes com resina composta $^{72,73,93}$. Já núcleos metálicos fundidos cônicos totalmente adaptados a condutos alargados geram efeito de cunha, causando um alto índice de fraturas radiculares extensas, que normalmente condenam os dentes à extração ${ }^{115}$.

Foi recomendado que fossem melhor pesquisadas as qualidades mecânicas dos pinos dentários ${ }^{11,134}$. Da mesma forma, trabalhos acerca da utilização 
de núcleos de fibras de polietileno são muito escassos na literatura, sendo também indicadas pesquisas que demostrem a real efetividade deste material ${ }^{123}$.

Assim sendo, esta pesquisa justifica-se pelo fato de ser extremamente importante o desenvolvimento de um sistema de núcleos intra-radiculares com propriedades semelhantes àquelas da estrutura dentária e que possa reabilitar raízes estruturalmente enfraquecidas, evitando sua exodontia precoce e proporcionandolhes um prognóstico favorável. 


\section{REVISÃO DA LITERATURA}

PIERRE FAUCHARD ${ }^{36}$ apud RING $^{98}$, em 1989, publicou os primeiros registros oficiais da utilização de retentores intra-radiculares no ano de 1728, descrevendo uma técnica de confecção de coroas retidas por um pino de madeira inserido no conduto radicular. Com a umidade, o pino expandia-se, retendo as coroas. Em meados de 1880, teve início a utilização das coroas de Richmond, também conhecidas como "pivots", nas quais um pino metálico intra-radicular formava uma peça única com a coroa. A partir da década de 1960, as coroas "pivots" foram gradualmente abandonadas, devido à dificuldade para obtenção de paralelismo entre os pilares de pontes fixas, o qual tinha de ser obtido à custa das paredes dos condutos radiculares e também devido ao alto risco de fratura na remoção dos pinos de seu interior.

Tornou-se então mais rotineira a utilização dos núcleos metálicos fundidos, confeccionados separadamente da coroa. O núcleo metálico fundido é constituído de um pino intra-radicular, fixado no conduto previamente preparado, e de uma porção que reconstitui a porção coronária, como se o dente estivesse preparado para receber uma coroa total. A coroa é cimentada sobre a porção coronária do núcleo. Os núcleos metálicos fundidos podem ser obtidos em metais nobres, não-nobres ou seminobres, a partir de padrões de resina acrílica ou de cera confeccionados diretamente na boca do paciente ou indiretamente, em modelos de gesso dos preparos dentários ${ }^{105}$.

Com a evolução dos materiais dentários nas últimas décadas, foram surgindo inúmeros sistemas de pinos metálicos pré-fabricados, os quais possuem desenho, diâmetro, comprimento e textura de superfície previamente determinados, podendo ser ativos (rosqueados no interior do conduto) ou passivos (somente cimentados). Podem também ser classificados pela forma geométrica (cônicos ou paralelos) ou pela textura de superfície (lisos ou serrilhados) ${ }^{2,105}$. 
Mais recentemente, tem-se procurado desenvolver sistemas de núcleos intra-radiculares que proporcionem reforço à estrutura dentária debilitada, sem aumentar o risco de fratura do remanescente dentário e que, simultaneamente, não interfiram deleteriamente com a estética do mesmo. Essa busca tem impulsionado a pesquisa de núcleos não-metálicos. Deseja-se hoje alcançar a denominada restauração em monobloco, isto é, obtenção de um único complexo biomecânico pela adesão entre as estruturas dentárias e os materiais de reforço (pino, agente cimentante e material de preenchimento coronário) e pela utilização de materiais com propriedades mecânicas semelhantes às da estrutura dentária remanescente ${ }^{40,41}$.

MARKLEY ${ }^{79}$, em 1958, descreveu uma técnica para utilização de pinos dentinários rosqueáveis para núcleos de preenchimento com amálgama. Estes pinos proporcionariam reforço e excelente retenção com mínima remoção de estrutura dentária, solucionando o problema da fragilidade inerente ao amálgama e reduzindo o risco de fratura.

SILVERSTEIN ${ }^{109}$, em 1964, afirmou que o reforço de dentes despolpados era necessário, pois após perdas importantes de estrutura por cárie e/ou tratamento endodôntico os dentes tornar-se-iam frágeis e mais predispostos à fratura. Recomendou a utilização de núcleos metálicos fundidos, que poderiam evitar fraturas dentárias horizontais ou longitudinais. Apresentou diversas técnicas para obtenção dos núcleos em dentes anteriores ou posteriores. Afirmou ainda que é mais vantajoso utilizar um núcleo metálico fundido ao invés de uma coroa "pivot" (coroa e núcleo como peça única), por dois motivos: (1) coroa e pino são independentes, facilitando reparos ou trocas da coroa e (2) é mais fácil a obtenção de paralelismo entre os dentes pilares de uma prótese fixa, sem desgastes excessivos das raízes.

Em 1967, BARABAN ${ }^{5}$ afirmou que dentes despolpados são mais frágeis devido à desidratação e que deveriam ser protegidos contra fraturas. Descreveu diversos métodos para obtenção desta proteção, incluindo: núcleos metálicos fundidos em ouro, associados ou não a pinos dentinários auxiliares; núcleos divididos; pinos metálicos pré-fabricados, entre outros. Conforme o autor, três fatores influenciam na seleção do método: 1) Quantidade de coroa clínica 
remanescente; 2) Finalidade para a qual o dente será utilizado; e 3) Oclusão e hábitos oclusais do indivíduo.

Em 1970, BARABAN ${ }^{6}$ descreveu o sistema de pinos metálicos ParaPost, que poderia ser utilizado através da técnica direta (com resina acrílica para a porção coronária) ou indireta (fundido). $\mathrm{O}$ conduto era preparado com uma broca de tamanho correspondente ao do pino. Os pinos eram fornecidos em cinco tamanhos e quatro materiais diferentes (ouro, aço inoxidável, alumínio e plástico). O autor observou que o sistema poderia ser utilizado na maioria das raízes de dentes unirradiculares, em sessão única, permitindo desenvolvimento de uma técnica simples e padronizada.

STANDLEE et al. ${ }^{118}$, em 1972, através de análise fotoelástica, investigaram a distribuição do estresse nas estruturas de suporte por pinos metálicos pré-fabricados com diferentes desenhos, durante a cimentação e sob cargas de cisalhamento e compressão. As formas de pinos utilizadas foram: 1) pinos cônicos lisos (1,4mm de diâmetro); 2) pinos de paredes paralelas e lisas $(1,4 \mathrm{~mm}$ de diâmetro); 3) pinos rosqueados (1,5mm de diâmetro). Cada pino foi testado com três comprimentos: 4mm, $7 \mathrm{~mm}$ e 10mm. Simularam-se raízes de incisivos centrais superiores nos modelos fotoelásticos e cimentaram-se os pinos nos condutos artificiais com fosfato de zinco. Sobre os pinos cimentaram coroas metálicas fundidas cilíndricas. A aplicação das cargas demonstrou que a concentração de estresse aumenta com pinos de comprimentos menores. Concluíram que o comprimento do pino deveria ser igual ou maior do que o comprimento da coroa anatômica. Recomendaram confecção de sulcos em pinos longos de paredes paralelas, para reduzir a alta pressão observada na cimentação. Pinos rosqueados deveriam ser utilizados com muita precaução para evitar fraturas radiculares devido ao alto estresse quando não adaptados adequadamente.

BARABAN $^{7}$, em 1972, descreveu um método para confecção de núcleos com resina composta autopolimerizável retida por pinos metálicos Para-Post, associados ou não a pinos dentinários auxiliares T.M.S. As vantagens da técnica seriam: economia de tempo; baixo custo; preparo imediato mesmo com pouco ou 
nenhum remanescente coronário; confecção simplificada da coroa provisória; adequada retenção e adaptação da resina ao remanescente dentário.

CAPUTO; STANDLEE ${ }^{23}$, em 1976, afirmaram que núcleos e/ou pinos devem ser utilizados quando a pequena quantidade de remanescente coronário não permite retenção de nenhum tipo de restauração, pois auxiliam na resistência ao deslocamento por forças mastigatórias. Observaram, porém, que núcleos ou pinos dentinários não reforçam as restaurações, e que na verdade as enfraquecem. Os pinos dentinários auxiliares teriam sua principal utilização em dentes vitais; a retenção é maior quando mais pinos são utilizados e quando não são paralelos entre si. Observaram que: pinos pré-fabricados, quando instalados em condutos precisamente preparados para recebê-los, exibem melhor performance que núcleos metálicos fundidos; pinos de paredes paralelas exibem melhor retenção e capacidade de distribuição de estresse que cônicos (os últimos causam efeito de cunha); pinos rosqueados são os que geram maior estresse na dentina. Pinos retidos por fricção possuem retenção intermediária e os cimentados possuem a menor retenção. Pinos de grandes diâmetros deveriam ser evitados, pois debilitam a raiz; pelo menos $1 \mathrm{~mm}$ de dentina sadia deveria ser mantida em torno do pino. O comprimento do pino no conduto deveria ser igual ou maior que o da coroa clínica para retenção adequada.

TRABERT; CAPUTO; ABOU-RASS ${ }^{124}$, em 1978, investigaram a resistência à fratura de incisivos centrais superiores, divididos em três grupos experimentais: 1) sem tratamento (controle); 2) com tratamento endodôntico somente; 3) com tratamento endodôntico e instalação de pino de aço inoxidável com paredes paralelas serrilhadas (Para-Post). Em cada um dos grupos, foram testados dentes com três comprimentos de raízes: $11 \mathrm{~mm}, 13 \mathrm{~mm}$ e $15 \mathrm{~mm}$. Nos grupos 2 e 3 , foram executados dois diâmetros diferentes de preparo endodôntico: 1,4mm e $1,8 \mathrm{~mm}$. No grupo 3, foram utilizados pinos de $1,2 \mathrm{~mm}$ e de $1,7 \mathrm{~mm}$. A cavidade de acesso palatina foi fechada com resina composta. Não houve diferença estatística significante entre dentes não tratados e dentes tratados endodonticamente e nem entre o preparo endodôntico com os dois diferentes diâmetros. A resistência à fratura aumentou com pinos de menor diâmetro e raízes de maior comprimento. 
GUZY; NICHOLLS ${ }^{48}$, em 1979, observaram que dentes despolpados pareciam mais friáveis que dentes vitais, pois freqüentemente fraturam durante a função. Embora a literatura recomendasse reforçar estes dentes com núcleos intraradiculares para prevenir fratura, até aquele momento esta afirmação não possuía suficiente suporte científico. Assim, os autores compararam a resistência à fratura de dentes tratados endodonticamente com e sem pinos cimentados, visando determinar se pinos realmente reforçam as raízes. Utilizaram 59 incisivos centrais superiores e caninos inferiores tratados endodonticamente, divididos em quatro grupos: caninos com e sem pinos, e incisivos centrais com e sem pinos. Nos grupos com pinos, a obturação foi removida até $5 \mathrm{~mm}$ do ápice e pinos pré-fabricados Endo-Post foram cimentados com fosfato de zinco. Os pinos foram cortados $1 \mathrm{~mm}$ abaixo do acesso endodôntico, que foi restaurado com silicato. Os dentes foram fixados ( $2 \mathrm{~mm}$ abaixo da junção cemento-esmalte) em blocos de resina acrílica, sendo aplicada silicona de condensação sobre a raiz para simular ligamento periodontal. Cargas compressivas foram aplicadas sobre os dentes (de lingual para vestibular) na máquina de ensaios universal a um ângulo de $130^{\circ}$ em relação a seu longo eixo, à velocidade de $5 \mathrm{~cm} / \mathrm{min}$. Não houve diferença estatística significante no padrão de fratura ou localização da fratura (58 dentes fraturaram no terço médio ou cervical da raiz) entre dentes com e sem pinos, nem na resistência à fratura entre dentes com e sem pinos. Como as falhas iniciaram-se na face vestibular ou lingual das raízes, deduziram que o pino, dada sua posição, recebe estresse mínimo, reforçando muito pouco a raiz sob cargas externas; logo, quanto mais largo o diâmetro vestíbulo-lingual da raiz, maior sua resistência à fratura.

MATTISON $^{81}$, em 1982, utilizou modelos fotoelásticos para comparar a distribuição de estresse na dentina por núcleos metálicos fundidos em ouro de diâmetros diferentes. Dez modelos simulando incisivos centrais superiores foram utilizados: cinco com pinos de 1,25mm de diâmetro e cinco com pinos de $1,75 \mathrm{~mm}$ de diâmetro. A porção coronária dos núcleos foi construída com resina composta autopolimerizável. Após posicionamento dos modelos no polariscópio, cargas de compressão de $13,6 \mathrm{~kg}$ e de 27,2kg foram aplicadas sobre os mesmos. O estresse foi maior com o aumento do diâmetro e com o aumento da carga. O autor recomendou 
utilização de pinos de menor diâmetro para reduzir a carga sobre a dentina, principalmente quando grandes forças oclusais são exercidas pelo paciente.

SORENSEN; MARTINOFF ${ }^{117}$, em 1984, avaliaram 1273 dentes tratados endodonticamente com ou sem núcleos metálicos intra-radiculares (1 a 25 anos de tratamento), buscando estabelecer correlação com as taxas de sucesso clínico. Dividiram os dentes em seis grupos anatômicos: anteriores superiores, prémolares superiores, molares superiores, anteriores inferiores, pré-molares inferiores e molares inferiores. A utilização de núcleos intra-radiculares não aumentou significantemente a resistência à fratura em nenhum dos grupos em relação a dentes sem pinos. Os autores sugeriram que pinos metálicos não devem ser utilizados rotineiramente, pois não parecem ser realmente capazes de reforçar o remanescente dentário e substituir adequadamente a estrutura perdida.

Ainda em 1984, utilizando a mesma amostra acima, SORENSEN; MARTINOFF $^{116}$ pesquisaram a relação entre desenho, configuração de superfície e comprimento dos núcleos com a taxa de sucesso clínico. Os sistemas que mostraram taxas de sucesso mais altas foram pinos de paredes paralelas serrilhadas (Para-Post) com porção coronária fundida (100\%) e pinos Para-Post com preenchimento coronário em amálgama ou resina composta $(97,7 \%)$. Dentes com núcleos metálicos fundidos cônicos exibiram menor taxa de sucesso $(87,3 \%)$ que dentes sem reforço intra-radicular $(89,9 \%)$. Além disso, os dentes com pinos Para-Post não falharam por fratura radicular, enquanto cerca de um terço dos dentes com núcleos metálicos fundidos cônicos foram extraídos devido a fraturas radiculares não-restauráveis. Ressaltaram que quando os pinos possuíam comprimento igual ou maior que o da coroa o sucesso foi de mais de $97 \%$.

TROPE; MALTZ; TRONSTAND ${ }^{127}$, em 1985, compararam a resistência à fratura de dentes tratados endodonticamente restaurados por oito métodos diferentes. A amostra consistiu de 64 incisivos centrais superiores hígidos e de dimensões similares. A cavidade de acesso foi preparada com $2 \mathrm{~mm}$ de profundidade e $2 \mathrm{~mm}$ de largura, na face palatina dos dentes, que foram distribuídos em oito grupos: grupo 1 - cavidade de acesso preenchida com resina composta autopolimerizável; grupo 2 - cavidade de acesso preenchida com resina composta 
após condicionamento ácido; grupo 3 - conduto desobturado até $10 \mathrm{~mm}$ abaixo da junção cemento-esmalte e preenchimento do acesso e conduto com resina composta após condicionamento ácido; grupo 4 - preparo do conduto com broca Para-Post de $1,25 \mathrm{~mm}$ de diâmetro até $10 \mathrm{~mm}$ abaixo da junção cemento-esmalte, sendo o conduto mantido vazio e o acesso preenchido com resina composta; grupo 5 - conduto preparado da forma acima descrita, sendo acesso e conduto preenchidos com resina composta, sem condicionamento ácido; grupo 6 - conduto preparado como antes, condicionamento ácido do conduto e acesso, cimentação de pino de aço Para-Post (1,25mm de diâmetro) com fosfato de zinco e preenchimento do acesso com resina composta; grupo 7 - conduto preparado como antes, e após o condicionamento ácido o acesso e o conduto foram preenchidos com resina composta; grupo 8 - conduto preparado como antes, condicionamento ácido e cimentação de pino Para-Post com resina composta, utilizada também para preencher a cavidade de acesso. Os dentes foram fixados em anéis de cobre ao nível da junção cemento-esmalte e posicionados na máquina de ensaios universal para serem sujeitos a cargas compressivas até a fratura (ângulo de $50^{\circ}$ em relação ao longo eixo do dente). Todos os dentes fraturaram de modo similar, independentemente da técnica restauradora. Os grupos com melhor resistência à fratura foram os grupos 1, 2 e 3, sem diferenças significantes entre si. O preparo do conduto para o pino (grupos 4 a 7) enfraqueceu significantemente os dentes. Quando o pino Para-Post foi cimentado com fosfato de zinco (grupo 5) ou resina (grupo 8), os valores foram significantemente mais altos que quando o conduto preparado foi mantido vazio (grupo 4) ou preenchido com resina composta sem condicionamento ácido (grupo 5), mas significantemente mais baixos que nos dentes sem preparo do conduto (grupos 1 a 3). Quando o conduto preparado e o acesso endodôntico foram condicionados e preenchidos com resina composta (grupo 7), a resistência à fratura foi similar aos grupos 1 a 3 (sem preparo do conduto). Indicaram a técnica usada no grupo 7 para restauração de dentes jovens tratados endodonticamente com rizogênese incompleta (condutos largos e paredes radiculares finas). Os autores concluíram que dever-se-ia evitar preparo do conduto quando possível, utilizando pinos somente quando necessário para retenção da restauração. 
RABIE et al. $^{93}$, em 1985, baseados nos resultados da pesquisa anterior, testaram clinicamente a possibilidade de reforçar dentes imaturos com resina composta, restaurando três incisivos centrais superiores com fratura horizontal na região cervical. Em um dente a fratura era supragengival e em dois havia ocorrido abaixo da crista óssea. O acesso às raízes foi obtido com extrusão ortodôntica e/ou cirurgia periodontal. Após tratamento endodôntico e desobturação parcial do conduto, era executado condicionamento ácido e cimentação de pino ou núcleo metálico fundido no conduto com resina composta (dois casos) ou somente reforço com resina (um caso). Julgavam que a resina, penetrando nos túbulos dentinários condicionados, manteria as paredes radiculares unidas, possibilitando que o dente imaturo se tornasse restaurável. Recomendaram a técnica para reforçar raízes com paredes finas devido ao desenvolvimento incompleto, possibilitando a restauração e manutenção destes dentes na cavidade oral, os quais são rotineiramente extraídos devido ao maior risco de fratura vertical quando convencionalmente restaurados.

TJAN; WHANG ${ }^{124}$, em 1985, avaliaram a importância da espessura da parede vestibular do conduto radicular em relação à resistência à fratura sob carga de compressão horizontal. Cimentaram núcleos metálicos fundidos em 40 incisivos centrais superiores preparados de forma que a espessura de dentina vestibular na parede dos condutos fosse de $1 \mathrm{~mm}$ (grupo 1), $2 \mathrm{~mm}$ (grupo 3), $3 \mathrm{~mm}$ (grupo 3) e $1 \mathrm{~mm}$ com bisel de $60^{\circ}$ para formação de colar metálico (grupo 4). Os corpos de prova foram submetidos à compressão em máquina de ensaios universal. Não foram registradas diferenças significantes na resistência à fratura entre os quatro grupos, mas houve diferenças no padrão de falhas, relacionadas com a espessura da parede de dentina: no grupo 1 todas as raízes fraturaram; no grupo 2 fraturaram oito raízes; no grupo 3 somente duas raízes fraturaram; no grupo 4 fraturaram sete raízes. A utilização do colar metálico não aumentou a resistência à fratura.

$\mathrm{LUI}^{72}$, em 1987, sugeriu uma técnica para reforçar internamente as raízes debilitadas (por lesão cariosa, defeitos dentinários, causas iatrogênicas, etc), utilizando preenchimento interno da raiz com resina composta. Após tratamento endodôntico, a porção coronária sem suporte era eliminada, mantendo-se pelo menos $1 \mathrm{~mm}$ de altura acima da margem gengival para permitir término supragengival do 
preparo. O conduto era preparado com uma broca de tamanho compatível. A adaptação do pino de tamanho correspondente à broca era verificada no interior do conduto. Sulcos eram feitos com brocas tipo cone invertido nas paredes mais espessas. Seguia-se condicionamento com ácido fosfórico e aplicação do sistema adesivo. O pino (lubrificado com vaselina) era inserido no conduto e em torno dele era injetada e condensada resina composta radiopaca. Após a polimerização o pino era removido, formando o espaço para o núcleo. O preparo era terminado com brocas diamantadas e, para evitar rotação do núcleo, executava-se uma cavidade elíptica de 2 a $3 \mathrm{~mm}$ de profundidade na porção mais cervical da raiz. A técnica acima descrita permitiria a formação de um conduto retentivo e capaz de suportar um núcleo metálico fundido, evitando fratura de raízes enfraquecidas durante cimentação ou função mastigatória.

BARKHORDAR; RADSKE; ABBASI ${ }^{10}$, em 1989, avaliaram o efeito de núcleos metálicos fundidos com colar metálico de $2 \mathrm{~mm}$ de altura sobre a resistência à fratura de dentes tratados endodonticamente. No grupo 1, foram utilizados dez incisivos centrais superiores restaurados com núcleos possuindo colar metálico e no grupo 2 foram utilizados dez incisivos centrais superiores com núcleos sem colar. Cargas de compressão foram aplicadas na superfície palatina dos núcleos, à velocidade de $0,5 \mathrm{~cm} / \mathrm{min}$ e em ângulo de $135^{0}$ com o plano horizontal. As raízes restauradas com férula de $2 \mathrm{~mm}$ exibiram resistência à fratura significantemente maior que aquelas restauradas com núcleos sem férula.

SORENSEN; ENGELMAN ${ }^{114}$, em 1990, buscaram determinar o efeito de diferentes desenhos de pinos e da quantidade de adaptação do pino ao conduto na resistência à fratura de dentes endodonticamente tratados. Utilizaram 40 incisivos centrais superiores (quatro grupos de dez dentes). Após tratamento endodôntico, prepararam-se os condutos com brocas Peeso n 3 e removeram-se as coroas. Nos grupos 1 a 3 , os condutos foram preparados de forma afunilada, mantendo-se $1 \mathrm{~mm}$ de espessura da parede axial dos condutos na porção mais cervical da raiz. No grupo 4, o conduto não foi afunilado e a parede axial do conduto permaneceu com 2,5mm na porção coronária da raiz. A partir de pinos Para-Post calcináveis (paredes paralelas), foram fundidos núcleos de prata-paládio. No grupo 1, 
foi utilizado apenas pino Para-Post sem reembasamento, de modo que após cimentação este ficou envolvido por grande volume de cimento e adaptado somente no terço apical. No grupo 2, o pino foi reembasado para obtenção de núcleo cônico totalmente adaptado ao conduto. No grupo 3 , apenas os $2 \mathrm{~mm}$ mais cervicais do pino foram reembasados (adaptação parcial). No grupo 4, onde o conduto não foi afunilado, utilizoutse apenas o pino Para-Post (máxima adaptação). Cimentaram-se coroas metálicas sobre os núcleos e fixaram-se os dentes em blocos de resina acrílica com $2 \mathrm{~mm}$ de estrutura dentária acima da resina. Cargas de compressão foram aplicadas em ângulo de $135^{\circ}$ em relação ao longo eixo da raiz e à velocidade de 2,5mm/min. A força necessária para falha foi (em ordem decrescente): grupo 2 49,58kgf; grupo 3-29,47kgf; grupo 4 28,89kgf; e grupo 1-22,48kgf. O grupo 2 (pinos cônicos totalmente adaptados ao conduto) foi significantemente mais resistente à fratura que os demais, porém foi significantemente maior a quantidade de fraturas radiculares extensas que condenariam estes dentes à extração. Nos grupos 2 e 3 (pinos cônicos total ou parcialmente adaptados) a maioria dos dentes fraturou (17 de 20 dentes). Já nos grupos 1 e 4 (somente Para-Post com paredes paralelas) a quantidade de fraturas radiculares foi menor (50\% ou menos) e envolveu menos estrutura dentária. Apesar da maior espessura de cimento e da menor espessura de dentina no grupo 1 em relação ao grupo 4 (pino Para-Post totalmente adaptado), não houve diferença significante entre ambos.

Ainda no mesmo ano, SORENSEN; ENGELMAN ${ }^{115}$ examinaram o efeito de vários desenhos de férulas sobre a resistência à fratura de dentes despolpados com quantidades variáveis de estrutura coronária remanescente. Sessenta incisivos centrais superiores tratados endodonticamente foram distribuídos em seis grupos. Preparam-se os condutos com brocas Peeso $\mathrm{n}^{0} 4$ até $4 \mathrm{~mm}$ do ápice e instalaram-se pinos de aço Para-Post. No grupo 1, preparou-se ombro de $90^{\circ} \mathrm{e}$ removeu-se toda a estrutura coronária; o conduto foi alargado, mantendo-se $1 \mathrm{~mm}$ de espessura da parede axial ao nível cervical. O grupo 2 foi preparado da mesma forma, porém sem alargamento do conduto. No grupo 3 foi preparado chanfro em $130^{\circ}$ e toda a coroa foi removida. Nos grupos 4, 5 e 6 , foram preparados ombro de $90^{\circ}$ e bisel de $1 \mathrm{~mm}$ de largura (na linha de término) com $60^{\circ}$ de inclinação. No grupo 4 , toda a coroa foi removida. No grupo 5 , manteve-se $1 \mathrm{~mm}$ de altura da dentina 
coronária e a união entre porção coronária do núcleo e estrutura dentária foi topo a topo. No grupo 6 , além de manutenção de $2 \mathrm{~mm}$ da dentina coronária, a união entre porção coronária do núcleo e estrutura dentária foi através de contra-bisel de $60^{0} \mathrm{com}$ $1 \mathrm{~mm}$ de largura. O padrão do núcleo foi feito a partir de pino Para-Post $n^{0} 4$ calcinável. Os testes foram executados em máquina de ensaios universal em ângulo de $130^{\circ}$ com o longo eixo do dente, à velocidade de $2,54 \mathrm{~mm} / \mathrm{min}$. As maiores resistências à fratura foram obtidas nos grupos 5 e 6 , seguindo-se em ordem decrescente os grupos 4, 3, 1 e 2. Os valores dos grupos 5 e 6 foram significantemente mais altos que os dos demais grupos, mostrando que o fator crítico para aumento da resistência foi manter pelo menos $1 \mathrm{~mm}$ de estrutura dental coronária, para obtenção de efeito férula a partir das paredes aproximadamente paralelas. Não houve aumento da resistência nos grupos com paredes radiculares mais espessas. Os diferentes desenhos de férulas também não aumentaram a resistência à fratura.

No ano de 1990, DURET; REYNAUD; DURET ${ }^{31}$ apud MANNOCCI et al. ${ }^{77}$, em 1998, baseados nas excelentes propriedades físicas da fibra de carbono, com larga aplicação na indústria automobilística, aeroespacial e esportiva, idealizaram um sistema de núcleos intra-radiculares à base de fibras de carbono longas e em disposição paralela, imersas em matriz de resina epóxica. Este sistema, denominado em seu país de origem (França) como Composipost, baseia-se em um conceito de monobloco entre núcleo e raiz, pois as propriedades biomecânicas desse pino, especialmente o módulo de elasticidade (rigidez), são semelhantes às da estrutura dentária, além de ser adesivamente unido ao esmalte e à dentina. Segundo os pesquisadores, o sistema representou uma inovação em desenho, composição e performance na área de pinos pré-fabricados, apresentando-se originalmente como um núcleo passivo em dois estágios e disponível em três tamanhos, com brocas estandardizadas para o preparo dos condutos.

KING; SETCHELL ${ }^{65}$, em 1990, avaliaram a resistência à fratura de dentes restaurados com o protótipo de um pino de fibras de carbono. Compararam quatro sistemas de núcleos diferentes, empregando 40 dentes anteriores (incisivos centrais superiores e caninos inferiores ou superiores). Os pinos de fibra de carbono 
(grupos experimentais) tiveram a porção coronária fundida em ouro (grupo B) ou construída com resina composta (grupo C) e foram cimentados com cimento resinoso. Foram utilizados dois grupos controle (cimentados com fosfato de zinco): um com pinos de liga preciosa (Para-Post) com porção coronária fundida em ouro (grupo A) e outro com pinos de aço inoxidável (Para-Post) com porção coronária em resina composta (grupo D). Após receberem coroas metálicas fundidas, os espécimes sofreram cargas compressivas em ângulo de $130^{\circ}$ com o longo eixo da raiz. Dentes restaurados com pinos de fibras de carbono exibiram desempenho comparável (em alguns espécimes até melhor) àquele dos pinos metálicos. O modo de falha (nível de fratura) de dentes restaurados com pinos de fibra de carbono foi mais favorável para o remanescente dentário que o dos pinos metálicos.

SORNKUL; STANNARD ${ }^{118}$, em 1992, avaliaram a resistência à fratura vertical e lateral de pré-molares inferiores antes e após procedimentos endodônticos e restauradores. Empregaram 140 pré-molares inferiores, distribuídos em sete grupos. No grupo 1 (controle), os dentes não receberam tratamento endodôntico nem restaurador, mas somente preparo coronário. Em todos os outros grupos, as raízes foram endodonticamente tratadas, a porção interna das coroas foi alargada para obtenção de uma forma afunilada (abertura vestíbulo-lingual de $3 \mathrm{~mm}$ e mésio-distal de $2 \mathrm{~mm}$ ) e um preparo para coroa total com $5 \mathrm{~mm}$ de altura foi executado. No grupo 2, resina composta autopolimerizável (sem agente de união) foi utilizada para preenchimento coronário. No grupo 3, a mesma resina foi utilizada, porém com agente de união. No grupo 4, o conduto foi preparado até $10 \mathrm{~mm}$ de profundidade com a broca $\mathrm{n}^{0} 4$ do sistema Para-Post ( $1 \mathrm{~mm}$ de diâmetro) e um pino deste sistema com tamanho equivalente foi cimentado com resina composta associada a agente de união. O preparo nos grupo 5 e 6 foi similar ao do grupo 4 . No grupo 5 obteve-se um núcleo metálico fundido, que foi cimentado com fosfato de zinco. No grupo 6, nenhum tratamento restaurador foi executado, para determinar a resistência do dente tratado endodonticamente e preparado para coroa total, mas não restaurado. No grupo 7, foram confeccionados "dentes" de resina composta autopolimerizável usando como molde uma raiz preparada, para determinar a resistência de "dentes" totalmente reforçados e a possibilidade da utilização de grandes quantidades de resina para reforçar raízes. Em uma máquina de ensaios 
universal, foram aplicadas cargas compressivas (perpendiculares à superfície oclusal) e de cisalhamento (ângulo de $45^{\circ}$ em relação ao longo eixo da raiz). Os grupos com maior resistência foram o grupo 1 (raízes inalteradas) e o grupo 3 (resina composta com agente de união). Quando cimentados pinos pré-fabricados com resina composta (grupo 4), a resistência do dente diminuiu; a resistência do grupo 7 foi similar à do grupo 4. Preenchimento com resina composta sem agente de união (grupo 2) e núcleo metálico fundido (grupo 5) foram os próximos na magnitude. O grupo de menor resistência foi o dos dentes preparados sem qualquer restauração (grupo 6). Os autores concluíram que os fatores que auxiliaram a evitar fraturas foram: quantidade de estrutura dentária remanescente; resistência dos pinos e material de preenchimento coronário; e adesão entre dentina e material de preenchimento coronário. Sugeriram pesquisas de materiais para aumento da adesão entre materiais restauradores e estrutura dentária, permitindo seu reforço e preservação.

MILOT; STEIN ${ }^{83}$, em 1992, investigaram o papel do bisel na resistência à fratura de 48 dentes plásticos padronizados transparentes (simulando incisivos centrais) divididos em três grupos de 16 dentes. No grupo 1 foram cimentados núcleos metálicos fundidos (diâmetro variável de $0,8 \mathrm{~mm}$ na porção apical a 2,8mm na porção cervical). No grupo 2, foram utilizados pinos Para-Post Plus $n^{0} 5$ (1,15mm de diâmetro). No grupo 3, foram utilizados pinos Flexi-Post $n^{0} 1$ (1,1 mm de diâmetro). Para costrução da porção coronária do núcleo nos grupos 2 e 3 empregou-se ionômero de vidro reforçado com prata. Metade dos dentes de cada grupo permaneceu intacta (somente com chanfro) e metade recebeu um bisel côncavo (férula) com $1 \mathrm{~mm}$ de diâmetro. Sobre os núcleos, foram cimentadas coroas metálicas fundidas. Forças compressivas foram aplicadas por lingual à velocidade de $50 \mathrm{~mm} / \mathrm{min}$ e com inclinação de $120^{\circ}$ em relação ao longo eixo da raiz. Espécimes com bisel (férula) de 1mm exibiram maior resistência à fratura. Além disso, fraturas verticais ocorreram em quantidade duas vezes maior com preparos não-biselados. $\mathrm{O}$ tipo de pino teve pouco ou nenhum efeito sobre a resistência final.

TROPE; RAY ${ }^{126}$, em 1992, determinaram a resistência à fratura de 48 caninos inferiores tratados endodonticamente e obturados com cimento endodôntico de ionômero de vidro (Ketac Endo), sob cargas compressivas. Foram preparados 
quatro grupos (12 dentes cada). No grupo 1, os condutos instrumentados foram obturados com cimento de ionômero de vidro; no grupo 2 , os condutos não foram instrumentados; no grupo 3, os canais foram instrumentados, mas não obturados; no grupo 4, os canais instrumentados foram obturados com cimento endodôntico convencional (cimento de Roth). Instrumentação endodôntica do conduto enfraqueceu significantemente as raízes. A obturação com cimento endodôntico convencional não reforçou as raízes, enquanto que a obturação com cimento de ionômero de vidro reforçou significantemente as raízes quando comparadas com raízes instrumentadas mas não obturadas ou obturadas com cimento convencional.

MILLER $^{82}$ analisou, em 1993, um novo material à base de fibras de polietileno entrelaçadas, comercializado em forma de fitas sob o nome comercial de Ribbond. O material era originalmente indicado para esplintagem periodontal e retenção ortodôntica. Usos alternativos seriam: núcleos de preenchimento, próteses adesivas diretas ou indiretas, reforço de próteses provisórias para utilização a longo prazo, infra-estrutura de onlays, coroas e próteses parciais fixas de compósitos, reforço de dentes fraturados, reparo de cantilever fraturado de próteses implantossuportadas, reparo de próteses removíveis totais ou parciais e de aparelhos ortodônticos removíveis. As principais características físicas do material são: alto módulo de elasticidade, alta resistência à tração e baixa sorção de água (1\%). Segundo o autor, o Ribbond possui vantagens como: união química à resina composta ou acrílica; alta maleabilidade (quase sem memória elástica); cor branca, facilmente mascarada pela resina; estrutura entrelaçada, que fornece reforço multidirecional da resina e mantém a integridade estrutural (não desfia). A adesão com resinas deve-se ao tratamento eletroquímico da superfície com gás plasma: uma camada externa de $200 \mathrm{~A}^{\circ}$ torna-se quimicamente reativa, possibilitando que o material torne-se realmente parte da resina. As fitas de Ribbond são colocadas em uma câmara selada, que é preenchida por gás e simultaneamente exposta a altas cargas de energia elétrica. Para não contaminar a superfície reativa, o material não deve ser tocado por dedos desprotegidos, lençol de borracha ou luvas de vinil. O corte da fita deve ser feito com a tesoura especial fornecida pelo fabricante. A flexibilidade da fita permite amortecimento (dissipação do estresse) das forças funcionais ou parafuncionais presentes na cavidade oral, aumentando também a 
resistência à fratura. O autor descreveu vários casos clínicos de utilização do Ribbond.

ASSIF et al. ${ }^{4}$, em 1993, examinaram o efeito do desenho de pinos intra-radiculares na resistência à fratura de 41 pré-molares endodonticamente tratados e restaurados com coroas metálicas fundidas, divididos em quatro grupos: grupo 1, núcleos metálicos fundidos cônicos; grupo 2, pino cilíndrico Para-Post com porção coronária fundida; grupo 3, pino cilíndrico Para-Post com extremidade cônica e porção coronária fundida; grupo 4 , raízes sem pinos (preenchimento com ionômero de vidro). Foram mantidos $2 \mathrm{~mm}$ de margem de estrutura dental sadia apicalmente ao término da porção coronária do núcleo (para efeito de férula) e aplicadas cargas compressivas em ângulo de $30^{\circ}$ ao longo eixo da raiz. O desenho dos núcleos não influenciou na resistência à fratura e não houve diferença significante entre dentes com ou sem núcleos, quando o núcleo foi coberto com uma coroa total metálica com $2 \mathrm{~mm}$ de férula. Sugeriram que uma coroa total com férula de $2 \mathrm{~mm}$ distribuiria melhor o estresse para a raiz e núcleo, minimizando o risco de fraturas verticais, e que se a porção coronária está suficientemente preservada para poder fornecer retenção ao material restaurador, não é necessário utilizar pinos.

BOSCO; SILVEIRA; RAZABONI ${ }^{13}$, em 1993, relataram um caso clínico de utilização de núcleo biológico, confeccionado a partir de incisivo lateral conóide. Uma paciente jovem apresentou-se com fratura da porção coronária de um incisivo lateral superior. Inicialmente foi feita remoção parcial da guta-percha do conduto do incisivo lateral. Seguiu-se ajuste por desgaste do dente conóide (obtido em banco de dentes e esterilizado em autoclave) até sua adaptação no conduto do incisivo. O núcleo biológico foi cimentado com ionômero de vidro autopolimerizável e a coroa restaurada com resina composta fotopolimerizável. Segundo os autores, esse tipo de núcleo representa mais uma alternativa clínica para casos de dentes desvitalizados onde restaurações extensas de resina composta irão ser executadas, aumentando a retenção e estabilidade para as mesmas.

A influência de pinos na distribuição do estresse na dentina foi investigada por $\mathrm{HO}$ et al. ${ }^{51}$, em 1994, através do método do elemento finito. Foram idealizados modelos contendo incisivos centrais superiores endodonticamente 
tratados com ou sem pinos (fundidos em ouro ou pré-fabricados de aço inoxidável). Dois tipos de carga foram aplicados: forças linguais simulando mastigação (ângulo de $45^{\circ}$ ) e forças traumáticas aplicadas horizontalmente na face vestibular da coroa, ambas com 100N. O uso de pinos não diminuiu significantemente o estresse (nem compressivo e nem à tração) na dentina em relação à restauração sem pinos. Concluíram que o efeito benéfico de reforço de núcleos fundidos ou pinos préfabricados em dentes endodonticamente tratados é duvidoso.

ROVATTI; MASON; DALLARI ${ }^{99}$, em 1994, investigaram a resistência à tração do Composipost com os cimentos resinosos Sealbond e Flexiflow, obtendo média de $73 \mathrm{~kg} / \mathrm{cm}^{2}$ para o primeiro e de $72 \mathrm{~kg} / \mathrm{cm}^{2}$ para o segundo. Relataram também que a força necessária para remover fibras de carbono da matriz de resina epóxica é de $75-78 \mathrm{~kg} / \mathrm{cm}^{2}$. Como o pino é liso e não tem a mesma retenção mecânica dos pinos serrilhados, toda a retenção é dada pela adesão; isto foi confirmado com a cimentação de dois pinos em pré-molares superiores, pois a força de tração necessária para removê-los manteve-se na média de $73 \mathrm{~kg} / \mathrm{cm}^{2}$. Testaram ainda um protótipo do fabricante, denominado Composipost Retentivo (possuindo sulcos de média profundidade, a intervalos regulares) com cinco cimentos diferentes: Sticky Post, Flexi Flow, Seal Bond, Super Bond e All Bond II. Os resultados dos testes de resistência à tração foram, respectivamente $\left(\mathrm{em} \mathrm{kg} / \mathrm{cm}^{2}\right): 88$, 88, 92, 120 e 127. Os autores observam que os valores obtidos com Super Bond e com All Bond II foram os melhores já obtidos com pinos passivos. Consideraram excelente a idéia de um pino passivo com elasticidade semelhante à da dentina $\mathrm{e}$ adesivamente unido às paredes do conduto, bem como muito promissor o conceito de restauração em monobloco (união entre materiais heterogêneos através da adesão).

Em 1994, LUI $^{73}$ descreveu uma técnica para reforçar raízes com condutos excessivamente alargados através de seu preenchimento com resina composta fotopolimerizável. Para melhor polimerização da resina nas porções mais profundas do conduto, indicou o pino plástico fototransmissor Luminex, que permite obtenção de um conduto preciso ao qual se adaptam outros pinos (componentes do sistema Luminex) de tamanho e forma idênticos, que podem ser de aço inoxidável, 
titânio, ouro ou mesmo calcináveis (para fundição do pino). A técnica permite aproveitamento de raízes que de outra forma seriam indicadas para extração.

Em 1995, HORNBROOK; HASTINGS ${ }^{54}$ apresentaram um método de confecção de pinos com fibras de polietileno (Ribbond). Afirmaram que em condutos alargados os núcleos metálicos fundidos são contra-indicados (devido ao efeito de cunha). Pinos pré-fabricados também não são ideais, pois a adaptação geralmente é inadequada e o excesso de cimento que permaneceria em torno do pino gera um prognóstico desfavorável. Além disso, o resultado será antiestético quando utilizadas coroas de cerâmica pura. O pino de fibras de polietileno é adesivo, anti-rotacional e passivo, sendo indicado inclusive para canais alargados. Formaria uma unidade com a raiz pela união de materiais adesivos entre si, reforçando-a e reduzindo o risco de fratura. Também impediria propagação de trincas já existentes nas paredes até o periodonto e não compromete a estética da restauração. Para sua confecção, removese guta-percha de modo a permitir obtenção de um pino com comprimento gual à altura da porção coronária do núcleo. A largura de fita mais usada para pinos é $2 \mathrm{~mm}$; a de $3 \mathrm{~mm}$ pode ser usada em canais largos e a de $4 \mathrm{~mm}$ em câmaras pulpares de molares inferiores. O comprimento da fita deve equivaler à cerca de três vezes o do conduto, medido com sonda periodontal. A fibra é impregnada com adesivo fotopolimerizável sem carga. O remanescente dentário sofre condicionamento ácido e o sistema adesivo é aplicado. Cimento resinoso dual, híbrido e com carga é injetado no conduto com a ponta agulha da seringa Centrix. A fita dobrada é levada ao conduto com condensador endodôntico, preenchendo-o totalmente. Em condutos largos insere-se ainda uma segunda fita com 1,5 vezes o comprimento do canal. O conjunto é fotopolimerizado e uma resina híbrida é condensada e fotopolimerizada em torno das fibras que emergem do conduto para construir a porção coronária do núcleo. Os autores utilizaram a técnica em 24 casos durante 12 meses, sem nenhuma falha clínica, mesmo naqueles dentes severamente comprometidos.

Em 1995, LIBMAN; NICHOLLS ${ }^{70}$ avaliaram a influência da altura da férula sobre a resistência a fratura de incisivos centrais superiores restaurados com núcleos metálicos fundidos. Espécimes de quatro grupos experimentais receberam coroas totais com altura de férula variando de 0,5 a $2,0 \mathrm{~mm}$, em incrementos de 
0,5mm; um quinto grupo (controle) não recebeu núcleos. Aplicaram-se cargas cíclicas (72 ciclos por minuto) em ângulo de $135^{\circ}$ em relação ao longo eixo do dente. O número de ciclos necessários para causar falha preliminar por fadiga (perda de selamento entre coroa e dente por fratura do cimento) foi significantemente menor com férulas de $0,5 \mathrm{~mm}$ e $1,0 \mathrm{~mm}$ do que com férulas de $1,5 \mathrm{~mm}$ e $2,0 \mathrm{~mm}$ e do que no grupo controle.

Em 1996, DURET; DURET; REYNAUD ${ }^{30}$ descreveram o efeito do módulo de elasticidade na transmissão da força para a dentina que envolve o pino. Foram cimentados três pinos de formas idênticas e materiais diferentes em incisivos centrais superiores: níquel-cromo (módulo de elasticidade de 210GPa), titânio (módulo de elasticidade de 110GPa) e pino de fibras de carbono C-Post (módulo de elasticidade de 8GPa). Foi aplicada carga de $1 \mathrm{~N}$ na borda incisal do dente, perpendicular ao longo eixo do dente e do pino $\left(\mathrm{em} 90^{\circ}\right.$ ). Nos pinos com módulo de elasticidade mais alto, maior força é transmitida para a dentina. Concluíram que o pino ideal deveria possuir módulo de elasticidade próximo ao da dentina. Realizaram também testes de resistência à fadiga em máquina de ensaios universal, comparando dois pinos de fibras de carbono (C-Post e Endo-Composipost) com três pinos metálicos: Para-Post, Flexi-Post e Adpost, todos com diâmetro semelhante ao CPost. Após aplicação das cargas cíclicas, foi observado que pinos de fibra de carbono resistiram melhor à fadiga que os metálicos, os quais deformaram progressivamente. Somente dois C-Post fraturaram durante os testes, enquanto os pinos metálicos freqüentemente fraturavam antes do fim da série de ciclos. Observaram suave queda na resistência à fratura (menos de 20\%) para o C-Post ao final do teste, mas os pinos metálicos não possuíam praticamente mais nenhuma resistência. A elasticidade não foi afetada no C-Post, mas decresceu muito nos pinos metálicos. Concluíram que com pinos de fibras de carbono o risco de fratura radicular diminui, pois as deformações ocorridas com pinos metálicos levam a trincas da dentina. As fibras de carbono são unidas por uma matriz de resina epóxica; são longas, orientadas unidirecionalmente no longo eixo do pino e eqüitativamente distribuídas no mesmo. O pino tem forma cilíndrica e dois estágios, um cervical com maior diâmetro e um apical com menor diâmetro. O ápice é cônico para maior estabilização. Seu módulo de elasticidade varia de $8 \mathrm{GPa}$ a $110 \mathrm{GPa}$. Com ângulo de incidência de $90^{\circ} \mathrm{em}$ 
relação ao longo eixo do pino, o módulo é de 8GPa (próximo ao da dentina radicular); com ângulo de incidência de 20 a $45^{\circ}$ em relação ao longo eixo do pino, o módulo é de 18 a 30GPa (próximo ao da dentina); com ângulo de incidência de $0^{\circ}, \mathrm{o}$ módulo é de 100 a $110 \mathrm{GPa}$. A resina epóxica tem excelente adesão às resinas compostas e cimentos resinosos, pois nos testes de resistência à fratura esta geralmente é coesiva.

Segundo FREEDMAN ${ }^{41}$, em 1996, os componentes do pino de fibra de carbono são fibras, matriz e interface. As fibras de carbono têm 8ìm de diâmetro, são contínuas e longitudinalmente dispostas nos pinos, formando sua estrutura interna. Representam $64 \%$ do peso total, conferindo alta resistência ao pino. A arquitetura interna absorve os esforços aplicados à prótese, redirecionando-os para 0 longo eixo da raiz. A matriz (36\% do peso total) é uma resina epóxica que envolve as fibras. A interface é a área de união da fibra com a matriz, através de agentes de adesão adequados. Salientou que quando o estresse transmitido pelos pinos à estrutura dentária foi comparado entre pinos de níquel-cromo, titânio e de fibras de carbono, este último transmitiu somente cerca de $65 \%$ de esforços em relação ao Ti e somente um terço em relação ao níquel-cromo. Pinos metálicos, por possuírem módulo de elasticidade até dez vezes maior que o da estrutura dentária, geram alto estresse na interface dente-cimento-pino, podendo gerar descimentação do pino ou fratura da raiz. O pino de fibra de carbono possui módulo de elasticidade similar ao da dentina. As propriedades adesivas do pino também auxiliariam no aumento da resistência do remanescente dentário e na diminuição da micro-infiltração. A forma do pino - um cilindro formado por dois cones - respeita a forma cônica do canal, e cada cone gera uma parada para estabilização vertical e distribuição do estresse. Após mais de um bilhão de cargas consecutivas em pinos de fibras de carbono não houve fratura de nenhum pino, e somente $30 \%$ das raízes sofreram fratura longitudinal. Quanto a estudos clínicos, 89 profissionais trataram mais de 1100 pacientes com esses pinos, que após três anos estavam todos intactos. Ocorreu uma pequena porcentagem de falhas $(2 \%)$, atribuídas à falta de manutenção periodontal e lesões periapicais. 
A influência da dimensão de núcleos metálicos fundidos sobre a distribuição do estresse na dentina foi investigada por HOLMES; DIAZ-ARNOLD; LEARY $^{53}$, em 1996, através do método do elemento finito. Foi simulada uma secção cilíndrica da mandíbula (osso e tecido mole) contendo um canino inferior endodonticamente tratado e restaurado com núcleo metálico fundido e coroa metalocerâmica. Foram utilizados seis tipos de núcleos: 1) paredes paralelas $(1,4 \mathrm{~mm}$ de diâmetro e $13 \mathrm{~mm}$ de comprimento); 2) paredes paralelas (1,4mm x 10,5mm); 3) paredes paralelas $(1,4 \mathrm{~mm} \times 8 \mathrm{~mm})$; 4) paredes paralelas $(1,2 \mathrm{~mm} \times 13 \mathrm{~mm}) ; 5)$ paredes paralelas $(1,6 \mathrm{~mm} \times 13 \mathrm{~mm})$; 6) cônicos $(0,6 \mathrm{~mm}$ a $1,4 \mathrm{~mm} \times 13 \mathrm{~mm})$. Carga de $100 \mathrm{~N}$ foi aplicada de vestibular para lingual, em ângulo de $45^{0}$ em relação ao longo eixo do dente. $\mathrm{O}$ estresse de cisalhamento aumentou quando o comprimento dos pinos foi diminuído. Variações na dimensão dos pinos não afetaram a distribuição do estresse de tração e de compressão.

SAUPE; GLUSKIN; RADKE ${ }^{104}$, em 1996, investigaram a possibilidade de reforçar raízes estruturalmente comprometidas com resina composta, restaurando internamente as paredes radiculares destruídas. Após remoção das coroas ( 1 a $2 \mathrm{~mm}$ acima da junção cemento-esmalte), 40 incisivos centrais superiores tratados endodonticamente foram distribuídos em quatro grupos: 1) raiz sem reforço e núcleo metálico fundido em ouro tipo III (sem férula); 2) raiz sem reforço e núcleo metálico fundido (com férula); 3) raiz com reforço e núcleo metálico fundido (sem férula); 4) raiz com reforço e núcleo metálico fundido (com férula). O desgaste da estrutura interna das raízes foi executado até $8 \mathrm{~mm}$ de profundidade, mantendo-se espessura de paredes radiculares de 0,5 a 0,75mm. Para auxiliar a polimerizar a resina composta, utilizou-se pino transiluminador Luminex. Os núcleos foram cimentados com cimento resinoso Enforce. Cargas compressivas foram aplicadas na face lingual dos núcleos à velocidade de $2 \mathrm{~mm} / \mathrm{min}$. Os grupos reforçados foram $50 \%$ mais resistentes à fratura que os grupos sem reforço. Nos grupos reforçados não houve diferença significante na resistência entre núcleos com ou sem férula (o que possibilita economia de estrutura dentária), possivelmente graças a um "abraçamento" ou "amarramento" interno fornecido pelas propriedades adesivas do sistema, que substitui a férula extracoronária. 
PURTON; LOVE ${ }^{92}$, em 1996, avaliaram rigidez e retenção de pinos de fibras de carbono lisos (Endopost) em relação a pinos de aço inoxidável serrilhados (Para-Post), ambos com 1mm de diâmetro. Os pinos foram cimentados com cimento resinoso em condutos endodonticamente tratados de incisivos e prémolares unirradiculares. Todos os condutos eram estreitos (cerca de $1 \mathrm{~mm}$ de diâmetro). Os pinos Para-Post demonstraram significantemente mais retenção e maior rigidez. É provável que a maior retenção do Para-Post seja devido à sua superfície serrilhada, enquanto o Endopost possui superfície lisa. Os autores concluíram que o pino Para-Post parece mecanicamente mais recomendável que o Endopost para restaurar dentes desvitalizados com condutos estreitos.

ISIDOR; ODMAN; BRONDUM ${ }^{58}$, em 1996, avaliaram a resistência à fratura de 40 dentes bovinos restaurados com pinos de fibras de carbono Composipost. O ligamento periodontal foi simulado com uma camada de $0,2 \mathrm{~mm}$ de silicona em torno das raízes, que foram fixadas em blocos de resina acrílica. $\mathrm{O}$ conduto foi preparado com duas brocas padronizadas até a profundidade de $8,5 \mathrm{~mm}$. Os pinos foram cimentados com cimento resinoso e a porção coronária foi restaurada com resina autopolimerizável. As coroas metálicas foram cimentadas com fosfato de zinco e os espécimes foram submetidos à carga intermitente $(250 \mathrm{~N}, 2$ cargas por segundo) em ângulo de $45^{\circ}$ em relação ao longo eixo do dente. Os resultados foram comparados a estudo prévio dos autores, conduzido sob condições similares, porém usando pinos metálicos paralelos Para-Post e núcleos metálicos fundidos cônicos em prata-paládio. Enquanto nenhum dos pinos de fibras de carbono falhou no segundo estudo (não houve perda ou fratura da coroa e nem do pino) até o número de ciclos de carga proposto, todos os núcleos metálicos fundidos e quase todos os pinos ParaPost do estudo prévio falharam (diferença estatisticamente significante). Somente quatro dos 14 espécimes com pinos de fibras de carbono mostraram fratura longitudinal incompleta. Os autores atribuíram a maior resistência à fratura do Composipost ao módulo de elasticidade próximo ao da dentina (melhor distribuição do estresse ao longo do pino), à forma do pino (paredes paralelas) e ao preparo mais conservador do conduto em áreas apicais críticas. 
O efeito do reforço com fibras de polietileno Ribbond sobre a resistência à fratura do polimetilmetacrilato autopolimerizável foi pesquisado por RAMOS JÚNIOR; RUNYAN; CHRISTENSEN ${ }^{95}$, em 1996. As fitas usadas possuíam 0,4mm de espessura, $4 \mathrm{~mm}$ de largura e $60 \mathrm{~mm}$ de comprimento. Confeccionaram-se 32 corpos de prova em forma de barra, sendo que em 16 espécimes as fibras foram inseridas em um ponto a $2 / 3$ da base da barra, de modo a localizar-se no lado da barra que sofreria tração; 16 espécimes não foram reforçados. A polimerização foi realizada em panela de pressão. Todos os espécimes foram mantidos em solução salina à temperatura ambiente por 12 a 24 horas antes de serem submetidos à carga em máquina de ensaios universal à velocidade de $5 \mathrm{~mm} / \mathrm{min}$. A resistência à fratura dos espécimes sem reforço foi $28 \%$ menor $(9,81 \mathrm{MPa})$ que a dos espécimes reforçados $(12,56 \mathrm{MPa})$, havendo diferença significante entre os grupos. Os autores ressaltaram que tratar um polímero com plasma aumenta sua energia de superfície. Plasma é um gás parcialmente ionizado contendo íons, elétrons e moléculas neutras com diferentes níveis de energia. Ao se energizar o plasma por um campo elétrico, formam-se radicais livres, íons e átomos que interagem com superfícies sólidas colocadas no plasma, gerando modificações químicas nestas superfícies. O aumento da energia de superfície aumenta a reatividade química e compatibilidade das fibras com outros materiais. Evidenciaram que as fibras impediam a propagação de linhas de fratura do ponto de compressão ao lado oposto da barra. Isto é excelente em próteses provisórias, pois ao invés de reconstruir toda a prótese (devido ao deslocamento total do fragmento), partes trincadas (mas não totalmente separadas) poderiam ser reaproximadas e reparadas. A adição de fibras aumentaria a resistência à fratura das próteses provisórias.

Em 1996, KARNA ${ }^{62}$ publicou os resultados de um estudo piloto sobre a utilização de núcleos com fibras de polietileno entrelaçadas Ribbond e resina composta. Para sua confecção, são removidos 6 a $7 \mathrm{~mm}$ de guta-percha, condicionase o conduto e aplica-se o sistema adesivo. Geralmente utiliza-se a fita de $2 \mathrm{~mm}$ de largura. Para determinar o comprimento da fita, mede-se o conduto com sonda periodontal; o valor obtido é multiplicado por 2 e então adiciona-se 16 a $20 \mathrm{~mm}$ para obtenção do comprimento final. As fitas são impregnadas com adesivo, cujo excesso deve ser removido. A fita é dobrada na forma da letra "V", cuja parte interna é 
coberta com cimento resinoso dual injetado com a ponta agulha da seringa Centrix, também utilizada para injetar cimento no conduto. Para condensar a fita no conduto utiliza-se o instrumento especial desenhado pelo fabricante ou um condensador endodôntico modificado. Se possível, insere-se uma segunda fita para melhor preenchimento do conduto. Coloca-se pequena quantidade de cimento entre as fitas que emergem do conduto, modela-se o pino e fotopolimeriza-se. Após condicionamento ácido do pino, aplica-se sistema adesivo e resina composta para confecção da porção coronária do núcleo. O autor confeccionou cinco espécimes com núcleos de fibras de polietileno, simulando diferentes situações: um $1^{0}$ pré-molar inferior, um incisivo lateral superior e um incisivo central inferior, todos sem coroa; um $1^{0}$ pré-molar superior com cúspide lingual removida; um $3^{0}$ molar superior com preparo para coroa total. Os dentes foram fixados em blocos de resina acrílica, $2 \mathrm{~mm}$ acima da junção cemento-esmalte. Duas fitas foram utilizadas em cada núcleo. Os espécimes foram submetidos à carga na máquina de ensaios universal em ângulo de $40^{\circ}$ em relação ao longo eixo (simulando cisalhamento). As forças necessárias para fraturar os espécimes foram na maioria superiores àquelas geradas intra-oralmente (resultados na Tabela 2.1). Na fase clínica dos testes, foram reconstruídos mais de 130 dentes com núcleos de Ribbond, observando-se somente dois casos de fratura de raiz, as quais possuíam as paredes radiculares com menos de $1 \mathrm{~mm}$ de espessura e três casos de fratura da resina composta coronária (situação passível de reparo). O tipo de falha mais comum destes núcleos seria a fratura somente da resina composta da porção coronária. Após remoção dos fragmentos, o núcleo pode ser reconstruído e a coroa recimentada. Estes núcleos possuiriam vantagens como: (1) Conservação da estrutura dentária - devido à adesão do núcleo ao conduto, este não precisa ser adicionalmente alargado; (2) Morfológica - o preenchimento do conduto tão completamente quanto possível, aliado à adesão do pino às suas irregularidades torna-o retentivo e não-rotacional; (3) Compatível com a flexibilidade da raiz - a flexibilidade das fibras e a adesividade minimizam a propagação de micro-fraturas radiculares; (4) Memória elástica mínima das fibras - facilita a inserção no conduto; (5) Estética - cor similar à do dente e ausência de corrosão; (6) Rápida remoção, com risco mínimo à estrutura dentária; (7) Custo similar ao dos pinos pré-fabricados. 
TABELA 2.1 - Valores de resistência à fratura e padrões de falha para dentes tratados endodonticamente restaurados com fibras de polietileno (KARNA,1996)

\begin{tabular}{c|c|c|c} 
Dentes / Situação de destruição & $\begin{array}{c}\text { Limiar de } \\
\text { falha (kgf) }\end{array}$ & $\begin{array}{c}\text { Fratura da } \\
\text { raiz }\end{array}$ & $\begin{array}{c}\text { Fratura ou } \\
\text { dano da porção } \\
\text { coronária }\end{array}$ \\
\hline $\begin{array}{c}\text { Incisivo superior com a coroa } \\
\text { removida }\end{array}$ & 45 & Não & Não \\
\hline $\begin{array}{c}\text { Incisivo inferior com a coroa } \\
\text { removida }\end{array}$ & 44 & Sim & Sim \\
\hline $\begin{array}{c}\text { Pré-molar inferior com a coroa } \\
\text { removida }\end{array}$ & 63 & Não & Fragmentação \\
\hline $\begin{array}{c}\text { Pré-molar superior com remoção da } \\
\text { cúspide lingual }\end{array}$ & 122 & Não & $\begin{array}{c}\text { Fragmentação } \\
\text { da resina }\end{array}$ \\
\hline $\begin{array}{c}\text { coroa total } \\
3^{0} \text { molar superior preparado para } \\
\text { coran }\end{array}$ & 390 & Sim & Sim
\end{tabular}

A utilização de um pino biológico para restaurar um dente anterior mutilado foi descrita por CENTOLA et al. ${ }^{25}$, em 1996. Uma paciente com 20 anos apresentoutse com fratura dos $2 / 3$ incisais do incisivo lateral superior direito. $\mathrm{O}$ pino biológico serviu como retenção adicional para a resina composta utilizada para restauração da coroa. Este pino foi confeccionado a partir do desgaste e adaptação de um incisivo inferior obtido em banco de dentes e cimentado com ionômero de vidro. De acordo com os autores, o pino biológico propicia maior retenção à resina composta que os demais tipos de pinos, pois pode ser submetido ao condicionamento ácido.

VILLA; ANDREOLLI ${ }^{128}$, em 1996, analisaram os custos de oito procedimentos restauradores para um incisivo central superior desvitalizado com fratura total da coroa. As opções foram: (1) núcleo biológico e reconstrução coronária em resina composta fotopolimerizável; (2) núcleo com pino metálico Radix-Anker e reconstrução coronária com resina composta fotopolimerizável; (3) 
núcleo com pino Radix-Anker, preenchimento com resina composta fotopolimerizável e coroa metalo-cerâmica; (4) núcleo com pino Radix-Anker, preenchimento com resina composta fotopolimerizável e coroa de porcelana pura; (5) núcleo com pino Radix-Anker, preenchimento com ionômero de vidro autopolimerizável e coroa metalo-cerâmica; (6) núcleo com pino Radix-Anker, preenchimento com ionômero de vidro autopolimerizável e coroa metalo-plástica; (7) núcleo metálico fundido (cobre-alumíno) e coroa metalo-cerâmica; e (8) núcleo metálico fundido e coroa metalo-plástica. A opção mais econômica foi o núcleo biológico associado à resina composta, com custo nove vezes menor que a segunda opção menos onerosa (pino Radix Anker e resina composta) e 70 vezes menor que a opção mais onerosa (pino Radix Anker e resina composta com coroa de porcelana pura). Os autores afirmaram que o pino biológico propicia excelentes resultados, pois possibilita ótimo acabamento e polimento, especialmente no terço cervical.

SAMADZADEH et al. ${ }^{102}$, em 1997, pesquisaram o efeito de fibras de polietileno entrelaças tratadas com plasma (Ribbond) no aumento da resistência à fratura de próteses parciais fixas provisórias. As resinas utilizadas foram (1) polimetimetacrilato Coldpac e (2) Provipont DC, baseada em uma resina de polimerização dual (poli-isocianato) similar à resina acrílica. Um modelo de polivinilsiloxano foi utilizado para fabricar próteses provisórias posteriores de três elementos em um troquel de aço inoxidável com 2 pilares separados pela distância de $22 \mathrm{~mm}$. Os grupos reforçados foram confeccionados fixando-se fitas de Ribbond (3mm de largura) nas superfícies oclusais dos pilares. Os espécimes foram divididos em quatro grupos (dez espécimes cada): (1) Provipont DC reforçado; (2) Provipont DC não-reforçado; (3) Coldpac reforçado; e (4) Coldpac não-reforçado. Cargas compressivas foram aplicadas no ponto central das próteses para determinar sua resistência à fratura. As restaurações de polimetilmetacrilato reforçadas com Ribbond não mostraram aumento significante na resistência à fratura quando comparadas com as restaurações não-reforçadas, porém as restaurações de Provipont DC reforçadas mostraram resistência à fratura significantemente mais alta que as restaurações de polimetilmetacrilato ou de Provipont DC sem reforço. Nos espécimes de Provipont DC reforçado as fraturas não se propagavam além das fibras. Os 
autores concluíram que o Ribbond pode efetivamente reforçar próteses parciais fixas provisórias, além de impedir a fratura completa.

No ano de 1997, MARCHI $^{78}$ avaliou a resistência à fratura de raízes debilitadas reconstruídas morfologicamente com sistema adesivo associado a pinos intra-radiculares. Empregou 76 raízes de incisivos centrais superiores ou caninos superiores. Em metade das raízes foi executado desgaste interno de dimensões padronizadas, simulando enfraquecimento; as raízes foram preenchidas com sistema adesivo e resina composta fotopolimerizável. As demais 38 raízes foram mantidas hígidas. Ambos os grupos foram subdivididos igualmente para receber pinos metálicos Radix-Anker (1,35mm de diâmetro) ou núcleos metálicos fundidos. Uma carga de compressão foi aplicada sobre os espécimes na máquina de ensaios universal, em ângulo de $135^{\circ}$ em relação ao longo eixo da raiz e à velocidade de 0,5 $\mathrm{mm} / \mathrm{min}$. Três fatores foram analisados: (1) volume da raiz (pequena, média ou grande), sendo que as maiores apresentaram maior resistência à fratura; (2) condição da raiz (hígida ou debilitada), mostrando-se as hígidas mais resistentes; (3) tipo de pino intra-radicular (núcleo metálico fundido ou pino metálico pré-fabricado), sendo que pinos pré-fabricados exibiram melhor performance. A interação entre raízes grandes, hígidas e com pinos pré-fabricados apresentou os melhores resultados de resistência à fratura. $\mathrm{O}$ autor concluiu que: a espessura de tecido dentinário remanescente em torno do núcleo está diretamente relacionada à capacidade de resistência da raiz à fratura; pinos de paredes paralelas, ativamente rosqueados na dentina, proporcionam maior resistência à fratura que núcleos metálicos fundidos cônicos; e que a resina composta não foi capaz de recuperar a resistência original do dente à fratura.

O estudo de DIETSCHI; ROMELLI; GORETTI ${ }^{29}$, em 1997, visou avaliar a adaptação de pinos cimentados com cimento resinoso à dentina após testes de resistência à fadiga. Avaliaram um pino experimental de zircônia, dois pinos de titânio (com cobertura resinosa ou cerâmica) e dois pinos de fibras de carbono. Os corpos de prova foram submetidos a cargas cíclicas e termociclagem. Secções dos espécimes foram observadas em microscópio eletrônico de varredura para verificar deficiências na interface entre materiais restauradores e dentina. O pino de titânio 
Komet ER exibiu as mais altas porcentagens de solução de continuidade ao nível de dentina coronária $(83,88 \%)$ ou radicular $(78,12 \%)$; também o pino de zircônia mostrou insuficiente adaptação à dentina coronária $(53,25 \%$ de continuidade) ou radicular $(21,25 \%$ de continuidade), demonstrando baixa capacidade de adesão à resina. O pino de fibra de carbono Composipost comportou-se melhor $(67,38 \%$ de continuidade ao nível radicular e 44,88\% ao nível coronário) que o pino de titânio Komet ER.

Em 1997, BURGESS; DOUGLAS; NORLING ${ }^{18}$ mediram a resistência à compressão, flexão e tração de dois pinos metálicos pré-fabricados (Para-Post e Para-Post XP) e dois pinos de fibras de carbono (C-Post liso e C-Post serrilhado), divididos em 12 grupos de 10 dentes cada. Pré-molares unirradiculares foram seccionados ao nível da junção cemento-esmalte e tratados endodonticamente. O conduto foi preparado com as brocas estandardizadas fornecidas pelos fabricantes até oito $\mathrm{mm}$ de profundidade. O C-Post foi jateado com óxido de alumínio. Os pinos foram cimentados com cimento resinoso Panavia 21 e os espécimes foram submetidos à carga até a falha do sistema. As resistências à flexão, tração e compressão de ambos os pinos de fibra de carbono foram significantemente menores que aquelas dos pinos metálicos.

No DENTAL PRODUCTS REPORT ${ }^{35}$, em 1997, descreveu-se um caso clínico no qual fibras cerâmicas (GlasSpan) foram utilizadas para confecção de núcleo. Afirmourse que um núcleo confeccionado com fibras minimiza o potencial para fraturas radiculares, além de aumentar a resistência à flexão e tração das resinas compostas. No kit de GlasSpan, há quatro configurações diferentes de fitas; a de maior largura tem a forma de um cordão oco, sendo a mais indicada para núcleos intra-radiculares. No caso descrito, apresentou-se uma paciente necessitando de coroa total no dente 13 . Cerca de ${ }_{3}^{2 /}$ da obturação radicular foram removidos. O conduto e o remanescente coronário foram condicionados com ácido fosfórico, sendo após aplicado o sistema adesivo. Uma gota de adesivo foi colocada na extremidade da fita em forma de cordão e fotopolimerizada por dez segundos, enrijecendo assim esta ponta para evitar escape de cimento. No outro extremo, a fita foi desfiada para permitir inserção de uma ponta agulha de seringa Centrix em seu interior. A fita foi 
toda coberta com adesivo, não polimerizado neste momento. Um cimento autopolimerizável fluido foi manipulado e inserido na ponta Centrix. Esta ponta foi usada para levar a fita até o conduto. A resina foi lentamente injetada enquanto a fita era inserida no canal. A força de extrusão da resina através da agulha impele sua passagem através das fibras para cobrir as paredes do conduto. A fita permaneceu no conduto e a agulha foi removida. As fibras que permaneceram fora do conduto foram recobertas com resina composta para confecção da porção coronária do núcleo.

SIDOLI; KING; SETCHELL ${ }^{106}$, em 1997, compararam resistência à fratura e padrão de fratura de pinos de fibra de carbono com outros sistemas de núcleos. Para construção da porção coronária do núcleo foi utilizada resina composta autopolimerizável e para a cimentação um cimento resinoso de baixa viscosidade. Distribuíram 40 incisivos centrais ou caninos superiores em quatro grupos de dez dentes. Carga estática compressiva de $2500 \mathrm{~N}$ foi aplicada sobre os espécimes com um ângulo de $130^{\circ}$ em relação ao longo eixo do dente. Os grupos pesquisados foram: (1) pino de fibras de carbono Composipost; (2) pino de aço inoxidável Para-Post e porção coronária de resina composta; (3) núcleos metálicos fundidos em ouro tipo III; e (4) dentes tratados endodonticamente sem núcleo. O grupo no qual não foram utilizados núcleos foi significantemente mais resistente que os demais, sugerindo que o preparo do conduto causou o enfraquecimento dos dentes. Os dentes restaurados com Composipost exibiram resistência inferior em relação aos demais sistemas, especialmente quando comparados com núcleos metálicos fundidos. Os autores conjeturaram que isso provavelmente ocorreu porque o pino de fibras de carbono não possui nenhum tipo de retenção mecânica para a resina da porção coronária. A carga necessária para fraturar o Composipost foi considerada inferior às forças mastigatórias normais, além do que seu potencial para flexão poderia levar à perda do cimento e micro-infiltração. A situação seria de maior risco se os dentes fossem utilizados como pilares para próteses parciais fixas ou removíveis. Contudo, o Composipost apresentou os melhores resultados em relação ao modo de fratura (60\% de fraturas favoráveis à preservação do remanescente dentário, ou seja, fratura somente do pino ou do dente acima do nível de inserção). Já com núcleos metálicos fundidos houve $100 \%$ de fraturas desfavoráveis, devido a seu alto módulo de elasticidade, que lhe proporciona baixa flexibilidade e o torna impróprio para 
absorver estresse. O modo de fratura deve ser sempre levado em consideração na seleção do núcleo.

A influência de diferentes procedimentos endodônticos e restauradores na resistência dos dentes à fratura foi avaliada por DEAN; JEANSONNE; SARKAR ${ }^{28}$, em 1998. No grupo controle executou-se somente preparo coronário (sem tratamento endodôntico); no grupo 2 executourse tratamento endodôntico e preparo coronário; o grupo 3 foi preparado como o grupo 2 e o acesso endodôntico foi restaurado com resina composta; o grupo 4 também foi preparado como acima e cimentoutse um pino de fibras de carbono no conduto. Nos grupos 5, 6 e 7 foram executados tratamento endodôntico, remoção das coroas, cimentação de três tipos de pinos (pinos de fibras de carbono, pinos de aço inoxidável cônicos e pinos de aço inoxidável paralelos) e construção da porção coronária em resina composta de polimerização dual. Os espécimes foram submetidos à carga compressiva em ângulo de $45^{\circ}$ em relação ao seu longo eixo, à velocidade de 0,5mm/min. Os grupos com pinos e porção coronária do núcleo em resina composta falharam com carga significantemente mais baixa do que aqueles nos quais a coroa não foi removida. Não houve diferença significante na resistência à fratura entre os grupos restaurados com diferentes tipos de pinos. Os dentes restaurados com pinos de fibras de carbono não sofreram nenhuma fratura de raiz, enquanto fraturas radiculares ocorreram em $50 \%$ dos dentes de cada um dos outros grupos onde foram usados pinos.

KAKEHASHI et al. $^{60}$, em 1998, analisaram um sistema de pinos cerâmicos (Cosmopost) introduzido em 1993, compostos por policristais tetragonais de zircônia. O sistema possui alta resistência à flexão (1400MPa). No início, as porções coronárias dos núcleos eram cimentadas aos pinos, porém em 1997, foi introduzida a cerâmica IPS Empress Cosmo Ingots, fundida diretamente sobre o pino de zircônia. Para dentes unitários, geralmente utiliza-se reconstrução direta: é feito um padrão de resina acrílica sobre o pino cerâmico e o técnico prensa a cerâmica diretamente sobre o pino, sem confecção de modelo de trabalho. O método indireto é utilizado para reconstruções simultâneas de mais de um dente; os pinos de zircônia são inseridos nos condutos, que são moldados para confecção de modelo de trabalho. 
O tamanho do núcleo após a prensagem é levemente maior que o padrão de resina original, sendo então condicionado com ácido hidrofluorídrico a $2 \%$ em ultrassom por sete minutos para melhorar a adaptação. A seguir executa-se jateamento com pérolas de vidro e limpeza com vapor. Os autores cimentaram 24 pinos Cosmopost com porção coronária de cerâmica fundida em 12 incisivos, 2 caninos e 10 prémolares, acompanhando-os pelo período médio de 15 meses (3 a 28 meses). Sobre os núcleos cimentaram coroas de porcelana pura IPS Empress. Nenhuma falha foi observada. Investigaram ainda a influência do condicionamento da superfície do pino cerâmico por jateamento com óxido de alumínio e o efeito da termociclagem na retenção da cerâmica fundida sobre os pinos. Os dados foram comparados com aqueles de espécimes nos quais a porção coronária do núcleo foi cimentada com cimento resinoso (grupo controle). Foram preparados quatro grupos experimentais de núcleos. Antes da fundição da porção coronária, os pinos de dois dos quatro grupos experimentais foram jateados com óxido de alumínio (50ìm). Dois dos quatro grupos experimentais foram sujeitos à termociclagem em água $\left(5 / 55^{\circ} \mathrm{C}\right)$ por 330 horas. Após armazenamento em água a $37^{\circ} \mathrm{C}$, os pinos sofreram compressão à velocidade de 5mm/min. Para pinos com superfícies não-tratadas, a técnica de cerâmica fundida apresenta retenção significantemente maior em relação à cimentação. Com os pinos jateados, não houve diferença na retenção entre as duas técnicas. Após termociclagem, as superfícies dos pinos jateados mostraram retenção significantemente mais alta que aquelas dos pinos que não foram jateados. Os autores concluíram que, no que tange à retenção da porção coronária, a fundição da porção coronária é tão adequada quanto a cimentação.

Em 1998, MONDELLI ${ }^{84}$ relatou que o desenvolvimento de pinos de dióxido de zircônia (Cerapost) ocorreu em 1993. O pino é composto de 94,9\% de dióxido de zircônia e estabilizado com $5,1 \%$ de óxido de ítrio. Sua resistência $\left(1400 \mathrm{~N} / \mathrm{mm}^{2}\right)$ é maior que a das cerâmicas aluminizadas de alta resistência (320$\left.500 \mathrm{~N} / \mathrm{mm}^{2}\right)$ e que a de materiais metálicos como aço comum $\left(450 \mathrm{~N} / \mathrm{mm}^{2}\right)$, além de próxima a àquela do aço carbide $\left(1600 \mathrm{~N} / \mathrm{mm}^{2}\right)$. Apresentam-se com $25 \mathrm{~mm}$ de comprimento e em 3 diâmetros (ISO 50, 90 e 110), na cor branco-opaca (esteticamente ideais para dentes anteriores e pré-molares). Pode ser utilizado com técnicas diretas ou indiretas. Na técnica direta é cimentado no conduto e revestido 
com materiais restauradores adesivos e na indireta a porção coronária é fundida com porcelanas reforçadas.

ROVATTI; MASON; DALLARI ${ }^{100}$, em 1998, relataram o desenvolvimento de pinos à base de fibras mais estéticos que os de carbono originais: o Aestheti-Post, com fibras de carbono recobertas por fibras estéticas (quartzo) dispostas longitudinalmente no pino e o Aestheti-Plus, um pino totalmente composto de fibras de quartzo em matriz resinosa. A resistência à flexão dos pinos estéticos (1200-1500Mpa), embora inferior à do Composipost (1900Mpa), é suficiente para os requisitos clínicos. A resistência à tração lateral é levemente menor para os pinos estéticos (50-60Mpa) que para o Composipost (65-95Mpa), porém isto facilita a remoção dos pinos para retratamento endodôntico, pois as brocas penetram facilmente entre as fibras. A resistência à tração longitudinal para os pinos estéticos é de 2480MPa. No teste de resistência à fadiga, estes pinos ultrapassaram cinco milhões de ciclos sem fratura. A carga necessária para fratura é adequada do ponto de vista clínico para o Aestheti-Plus $\left(92,65 \mathrm{kgf} / \mathrm{mm}^{2}\right)$ e para o Aestheti-Post $\left(98,57 \mathrm{kgf} / \mathrm{mm}^{2}\right)$. Testes com o Aestheti-Plus revelaram excelente resistência à descimentação (29,83MPa), maior que a do próprio Composipost (27,12MPa), mostrando adequada adesão das fibras estéticas minerais ao cimento resinoso. Os módulos de elasticidade do Aestheti-Post (55Gpa) e do Aestheti-Plus (44Gpa) são muito mais favoráveis para dissipação do estresse que o de qualquer pino metálico.

Em 1998, MANNOCCI et al. ${ }^{77}$ apresentaram um estudo sobre padrões de falhas e sobre taxas de sucesso de núcleos metálicos fundidos e pinos de fibra de carbono. Foram analisados, após três anos de cimentação, dentes restaurados com coroas totais metalo-cerâmicas onde foram cimentados 226 pinos de fibras de carbono e 194 núcleos metálicos fundidos. Com os pinos de fibras de carbono houve somente um caso de descimentação, sendo recimentados o pino e a coroa; não houve nenhuma fratura de raiz ou do pino. Já com os núcleos metálicos fundidos houve dez fraturas de raiz. A análise estatística demonstrou diferença significante entre os grupos, concluindo-se que a utilização de pinos de fibras de carbono e porção coronária do núcleo em resina composta praticamente eliminou o risco de fratura vertical de raiz. 
MARTINEZ-INSUA et al. ${ }^{80}$, em 1998, compararam a resistência à fratura entre dentes restaurados com pinos de fibras de carbono ou com núcleos metálicos fundidos. Foram utilizados 44 pré-molares, igualmente distribuídos para o grupo I, restaurado com pinos de fibra de carbono e porção coronária em resina composta e para o grupo II, restaurado com núcleos metálicos fundidos (ouro tipo III). Dimensão e forma dos pinos eram idênticos em ambos os grupos. Os dentes receberam coroas metálicas fundidas. Uma carga estática compressiva foi aplicada em ângulo de $45^{\circ}$ em relação ao longo eixo do dente. A resistência à fratura do grupo II foi quase o dobro que aquela do grupo I (diferença estatisticamente significante). No grupo II, contudo, houve fratura radicular em $91 \%$ dos espécimes (geralmente no terço cervical), enquanto que no grupo I houve somente 5\% de fraturas radiculares (no terço cervical). Os autores salientaram que cargas consideravelmente altas foram necessárias para gerar fraturas no grupo I (pinos de fibras de carbono) e que as cargas que provocaram fraturas dentárias no grupo II (núcleos metálicos fundidos) raramente ocorrem clinicamente.

IMPARATO $^{55}$, em 1998, observou que a colagem de fragmentos dentários está indicada em casos com grandes destruições coronárias por lesões cariosas, traumatismos ou distúrbios de formação e mineralização dos tecidos dentários, sendo geralmente realizada em dentes com tratamento endodôntico. Quando é necessária retenção intra-radicular, pinos podem ser confeccionados com dentes naturais (denominados pinos dentários). Para diminuir o tempo clínico, sugeriu preparo prévio de pinos com diferentes diâmetros, a partir de dentes unirradiculares decíduos ou permanentes. Os dentes são seccionados no sentido vestíbulo-lingual, e cada metade é desgastada na face voltada para o conduto. Obtêm-se dois pinos recobertos parte por esmalte e parte por dentina ou cemento. A parte recoberta por esmalte, que permanecerá fora do conduto, favorece a retenção da coroa pelo condicionamento do esmalte. Inicialmente avaliam-se as condições pulpares, periodontais e de rizólise do dente a restaurar. O terço cervical do conduto é desobturado, isolando-se a obturação radicular com ionômero de vidro. Os pinos são adaptados por desgaste utilizando-se pontas diamantadas. Confeccionam-se ranhuras na porção intra-radicular do pino, para aumentar o embricamento mecânico entre pino e material cimentante. A cimentação é feita com ionômero de vidro. 
Coroas destruídas podem ser restauradas com fragmentos dentários. As vantagens em relação às técnicas restauradoras diretas são o baixo custo e a redução do tempo clínico. As desvantagens são a necessidade de um banco de dentes e a relativa dificuldade para adaptação do fragmento ao preparo. Alternativamente, o técnico poderia adaptar os fragmentos, mas isto aumentaria o custo da restauração. Salientou ainda que restaurações biológicas são uma excelente alternativa, pois o material dentário possui propriedades mecânicas e estéticas ideais, ainda não reproduzidas por nenhum material restaurador. Para formar um banco de dentes adequado, que permita seleção de fragmentos de acordo com a morfologia de cada dente a restaurar, é preciso coletar dentes removidos ou esfoliados doados pelos pacientes ou pela população. A limpeza inicial é feita com água oxigenada 10 volumes, seguida por lavagem em água corrente. A esterilização em autoclave a $121^{\circ} \mathrm{C}$ por 40 minutos é eficaz e rápida, mas deve ser feita com o dente intacto, antes de qualquer preparo dentário. Se autoclavados após realização de preparos em dentina, há sensível redução na permeabilidade dentinária e, logo, redução da força de adesão dos adesivos dentinários. Os elementos dentários são classificados e acondicionados em frascos plásticos estéreis contendo soro fisiológico para evitar a desidratação, que os torna friáveis e prejudica a penetração de adesivos hidrofílicos.

FREDRIKSSON et al. ${ }^{39}$, em 1998, analisaram 236 dentes restaurados com pinos de fibras de carbono Composipost (130 superiores e 106 inferiores), com tempo médio de restauração de 32 meses (27 a 41 meses). Avaliaram condições periodontais e resultados protéticos (utilizando radiografias executadas logo após o tratamento). Cinco dentes (2\%) foram extraídos por razões não-relacionadas com os pinos (na maioria doença periodontal severa). As condições periodontais (índice de placa, sangramento à sondagem e profundidade de bolsa) nos dentes com Composipost foram similares aos dentes controle (contra-laterais ou similares em anatomia e posição). Não houve nenhum caso de deslocamento do pino ou das restaurações, nem fratura de raízes ou pinos. O exame radiográfico não revelou nenhum caso de reabsorção pronunciada da crista óssea. Estes resultados promissores indicaram que os pinos de fibras de carbono, os quais oferecem resiliência compatível com aquela do remanescente dentário e adesão ao mesmo, podem ser 
uma alternativa viável ao sistema de núcleos metálicos fundidos, que possui padrão de sucesso inferior.

WANDERLEY; TRINDADE; CORREA ${ }^{129}$, em 1998, citaram como alternativa para retenção intracanal a confecção de pinos de dentes naturais, obtidos em bancos de dentes. Estes pinos, quando utilizados em dentes decíduos, possuem a vantagem de serem reabsorvidos simultaneamente com os dentes. Após a adaptação da porção radicular dos pinos no conduto, pode-se executar a cimentação com cimentos resinosos duais ou cimentos de ionômero de vidro.

BUSATO et al. ${ }^{21}$, em 1998, consideraram que após sua equipe ter realizado mais de 80 casos de restaurações biológicas (classe I, II, III, IV e V) utilizando fragmentos dentários (obtidos a partir de dentes humanos esterilizados e armazenados em bancos de dentes), avaliadas por mais de cinco anos com excelentes resultados, a técnica pode ser considerada uma alternativa restauradora de grande potencial clínico e social. Suas vantagens são: uso de dentes naturais como material restaurador, estética, baixo custo e psicológicas (a maioria dos pacientes relata a "sensação de ter o dente de volta"). As desvantagens são: recusa por alguns pacientes (consideram "estranho dentes de outras pessoas em suas bocas"), dificuldade de obter dentes com morfologia e cor ideais e as dificuldades inerentes à confecção de restaurações indiretas. Os autores sugeriram a seguinte técnica para reconstruir dentes posteriores com fragmentos dentários: após preenchimento com resina composta ou ionômero de vidro (tipo cermet), é executado um preparo para coroa total, totalmente expulsivo (inclinação das paredes axiais de cerca de $6^{\circ}$ ). O término cervical deveria permanecer em esmalte. Molda-se o preparo para obtenção do modelo de trabalho. No modelo, o dente selecionado no banco de dentes de acordo com a cor e as dimensões desejadas é adaptado, após ter sua raiz seccionada ao nível da junção cemento-esmalte. A câmara pulpar é alargada com broca esférica em alta rotação até permitir adaptação do dente no preparo. Grafite é aplicado no modelo para facilitar a visualização dos pontos que dificultam a adaptação. A adaptação final é realizada em boca. Pode-se utilizar para a colagem cimentos adesivos duais, resinas compostas (autopolimerizáveis, duais ou fotopolimerizáveis) ou cimentos de ionômero de vidro. 
MOSCOVICH; CREUGERS ${ }^{87}$, em 1998, executaram um estudo preliminar visando desenvolver uma técnica para reciclar dentes extraídos (autógenos ou heterógenos), utilizando-os para confeccionar uma "inlay natural" em um sistema fresador Celay (CAD-CAM), originalmente idealizado para fresar blocos de porcelana. Dois pares de molares permanentes semelhantes foram selecionados de acordo com a dimensão mésio-distal de suas coroas e a convexidade das superfícies proximais. As raízes foram removidas $1 \mathrm{~mm}$ abaixo da junção cemento-esmalte. Um dos dentes foi o doador e o outro o receptor; neste último foi executado preparo para inlay. Inlays naturais foram fresadas no Celay a partir dos dentes doadores. Dentes receptores e inlays naturais sofreram condicionamento ácido e aplicação do sistema adesivo. As inlays foram cimentadas com cimento resinoso e o conjunto foi cortado em fatias no sentido vestíbulo-lingual com $1 \mathrm{~mm}$ de espessura, que foram coradas com azul de metileno e fucsina básica para exame microscópico. As observações demonstraram a localização desejada do esmalte (externamente) e da dentina (internamente) e adaptação clínica aceitável, semelhante àquela de inlays fresadas em cerâmica. O esmalte não foi danificado pela fresagem. Consideraram a técnica promissora e sugeriram pesquisas adicionais. Salientaram que nenhum material restaurador igualou até hoje todas as propriedades biomecânicas do dente natural, e por isso o tecido dentário deveria ser reciclado. O esmalte da inlay natural terá desgaste simultâneo ao dos dentes adjacentes e antagonistas, e a dentina funcionará como amortecedor elástico para o esmalte. Além disso, a inlay natural possui alta resistência, a técnica é conservadora, econômica e duradoura. Embora este tipo de restauração esteja sujeita à cárie, esta pode ser prevenida com terapia de flúor.

Segundo MONTENEGRO ${ }^{85}$, em 1998, a obtenção de núcleos pela técnica direta vem aumentando, por sua praticidade e rapidez. Os pinos préfabricados geralmente eram metálicos, mas recentemente uma nova tendência vem se delineando: a dos retentores não-metálicos, em que se associa um elemento de alta resistência com resinas compostas e sistemas adesivos. Esses elementos de alta resistência normalmente são fibras de carbono (por exemplo, C-Post), fibras de polietileno (por exemplo, Ribbond) ou fibras cerâmicas (por exemplo, GlasSpan). As fibras Ribbond e GlasSpan, originalmente indicadas para ferulização periodontal e contenção, vêm também sendo usadas para núcleos diretos. A principal indicação de 
retentores não-metálicos está em raízes com canal muito amplo ou comprometido por cárie, com paredes enfraquecidas. A resina composta indicada para cimentação e preenchimento coronário devem ser, preferencialmente, autopolimerizáve is ou de presa dual e radiopacas.

Em 1998, HOLLIS et al. ${ }^{52}$ estudaram a resistência à fratura de dentes despolpados e restaurados com sete tipos de pinos. Foram utilizados dois grupos controle: incisivos centrais superiores preparados mas não restaurados e incisivos restaurados somente com resina composta dual, sem pino. Os pinos utilizados nos grupos experimentais (cinco espécimes cada grupo) foram: 1) pino de fibra de carbono C-Post; 2) pino de fibra de carbono-quartzo Aestheti-Post; 3) pino de fibras de polietileno Ribbond (fita de $2 \mathrm{~mm}$ de largura); 4) pino de aço inoxidável Para-Post Plus; 5) pino de titânio 99\% puro Filpost; 6) pino de liga de titânio Para-Post Plus. Após tratamento endodôntico, a coroa foi removida e os dentes fixados em blocos de resina acrílica, $2 \mathrm{~mm}$ apicalmente à junção cemento-esmalte. Os pinos, cortados com $13 \mathrm{~mm}$ de comprimento, foram cimentados com cimento resinoso até a profundidade de $9 \mathrm{~mm}$. Confeccionou-se a porção coronária com resina composta dual $(5 \mathrm{~mm}$ de altura). No grupo controle de resina composta sem pino, o material foi injetado no conduto. Após termociclagem, uma carga compressiva foi aplicada em uma superfície horizontal preparada na face lingual do núcleo, com inclinação de $45^{\circ} \mathrm{em}$ relação ao longo eixo do pino, à velocidade de $1 \mathrm{~mm} / \mathrm{min}$. Todos os núcleos exibiram resistência significantemente maior que aquela de resina composta sem pino, exceto o núcleo de Ribbond (resistência similar à da resina sem pino). Todos os núcleos exibiram estatisticamente a mesma ou levemente maior resistência que a do dente preparado sem pino, exceto o de Ribbond e a resina sem pino (mais fracos). Os demais valores de resistência à fratura, em ordem decrescente, foram: pino de aço inoxidável - 69,13kgf; pino de titânio puro - 65,87kgf; pino de fibra de carbono 64,75kgf; pino de liga de titânio - 63,52kgf; pino cerâmico - 62,91kgf; pino de fibra de carbono com quartzo - 57,92kgf e igual valor para dente preparado sem pino; somente resina composta sem pino - 41,19kgf; núcleo de fibra de polietileno Ribbond e resina composta $-40,38 \mathrm{kfg}$. Com a resina sem pino normalmente ocorria fratura de raiz e deslocamento da porção coronária. No pino de Ribbond, as reconstruções coronárias eram lentamente esmagadas, e nos demais pinos geralmente 
fraturavam. Com o pino de Ribbond não houve fraturas dentárias. Com pinos metálicos a média de fraturas radiculares foi de $47 \%$, enquanto com pinos não metálicos esta foi de 33\%, exceto para o Aestheti-Post (60\% de fratura dentária). Em um segundo teste, os pinos foram inseridos diretamente nos blocos acrílicos (sem utilização de dentes humanos), sendo preparados três grupos (15 espécimes para cada pino). Pinos de Ribbond não foram utilizados na segunda fase. $\mathrm{O}$ primeiro grupo (controle) foi submetido somente à fratura de forma similar à descrita acima (primeiro teste); o segundo foi submetido à fadiga (15.000 ciclos com cargas alternadas de 5-50N) antes da fratura; no terceiro, após a fadiga, os espécimes foram imersos em água a $37^{\circ} \mathrm{C}$ por 24 horas antes da fratura. Os ciclos de fadiga não afetaram nenhum dos pinos, mas após imersão em água os pinos cerâmicos, de fibras de carbono e de carbono-quartzo mostraram-se estatisticamente mais fracos que os demais. Concluiu-se que embora os pinos metálicos tenham apresentado maior resistência que os não-metálicos, todos os sistemas testados exibiram um desempenho satisfatório para necessidades clínicas. Os menores valores obtidos para o pino de Ribbond foram provavelmente porque foi testada a resistência à compressão, sendo que o reforço com fibras geralmente não aumenta significantemente a resistência à compressão, mas principalmente à tração. Clinicamente, porém, a resistência às forças de tração é importante. Além disto, este pino possui vantagens em condutos largos e assimétricos.

O THE DENTAL ADVISOR ${ }^{38}$, em 1998, analisou as principais fibras existentes no mercado. Sobre as fibras de polietileno entrelaçadas Ribbond, observou-se que o material possui adequada resistência à tração, porém baixa resistência à compressão. Quanto à arquitetura, além das fibras entrelaçadas, há outras que correm perpendicularmente, formando um padrão especial que impede a fita de desfiar. O Ribbond necessita ser impregnado pelo adesivo antes da utilização. Como vantagem, o operador pode selecionar a resina. Porém, há várias desvantagens: a impregnação de todas as fibras é difícil; possível contaminação durante a manipulação; e maior dispêndio de tempo. O material é de fácil manipulação, adaptação e corte; incorpora-se facilmente à resina, com excelente compatibilidade de cor, boa adesão à resina e durabilidade. 
No ano de 1998, GOLDBERG et al. ${ }^{45}$ avaliaram módulo de flexão (módulo de elasticidade), resistência à flexão até o limite elástico e resistência à flexão máxima de três fibras comerciais não-impregnadas (Ribbond, Connect e GlasSpan), comparando-as com o produto pré-impregnado FibreKor (considerado o grupo padrão ou controle). A arquitetura das fibras foi examinada com microscopia eletrônica de varredura antes da impregnação com resina fluida sem carga. O conteúdo de fibras matriz resinosa também foi determinado. Espécimes em forma de barras com $2 \times 2 \times 25 \mathrm{~mm}$ foram preparados com as fibras paralelas ao seu longo eixo. Os resultados estão descritos na Tabela 2.2.

TABELA 2.2 - Resistência à flexão até o limite elástico, resistênc ia à flexão máxima e módulo de flexão de quatro fibras comerciais (GOLDBERG et al., 1998)

\begin{tabular}{l|c|c|c|c|c|c} 
Material & $\begin{array}{c}\text { Conteúdo } \\
\text { de fibras } \\
\text { (volume) }\end{array}$ & $\begin{array}{c}\text { Tipo de } \\
\text { fibra }\end{array}$ & $\begin{array}{c}\text { Arquitetura } \\
\text { da fibra }\end{array}$ & $\begin{array}{c}\text { Resistência } \\
\text { à flexão até } \\
\text { o limite } \\
\text { elástico } \\
\text { (MPa) }\end{array}$ & $\begin{array}{c}\text { Resistência } \\
\text { à flexão } \\
\text { máxima } \\
\text { (MPa) }\end{array}$ & $\begin{array}{c}\text { Módulo } \\
\text { de } \\
\text { flexão } \\
\text { (GPa) }\end{array}$ \\
\hline FibreKor & 42,5 & Vidro & Unidirecional & 471 & 539 & 28,3 \\
\hline GlasSpan & 27,7 & Vidro & Trançada & 266 & 321 & 13,9 \\
\hline Ribbond & 41,7 & Polietileno & Entrelaçada & 56 & 206 & 3,9 \\
\hline Connect & 39,0 & Polietileno & Trançada & 50 & 222 & 8,3
\end{tabular}

O conteúdo de fibras encontrado foi comparável entre Ribbond, FibreKor e Connect. A fibra de vidro com arquitetura unidirecional FibreKor atingiu o melhor desempenho. A resistência à flexão até o limite elástico das fibras de polietileno Ribbond e Connect foi significantemente menor que a da fibra de vidro FibreKor. As propriedades inferiores para Connect e Ribbond foram provavelmente devido à alta deformação que as fibras de polietileno sofrem sob compressão.

MANNOCCI; FERRARI; WATSON ${ }^{76}$, em 1999, compararam a resistência à fratura entre dentes restaurados com pinos de fibras de carbono recobertas por fibras de quartzo (Aestheti-Post), pinos de fibras de quartzo (AesthetiPlus) e pinos de dióxido de zircônia (Cerapost). Quarenta pré-molares inferiores 
endodonticamente tratados foram divididos igualmente em três grupos experimentais e um grupo controle sem pino. A obturação radicular foi removida até a profundidade de $8 \mathrm{~mm}$. A porção coronária do núcleo foi confeccionada com resina composta. Os dentes foram cobertos com coroas de cerâmica pura Empress e fixados em blocos de resina acrílica. Foram aplicadas cargas intermitentes (freqüência de dois ciclos por segundo) em ângulo de $45^{\circ}$ em relação ao longo eixo do dente. No grupo de fibras de carbono cobertas com quartzo e no grupo de pinos de fibras de quartzo ocorreu uma fratura em cada grupo (fratura da raiz mais pino); já no grupo de pinos de zircônia observaram-se seis fraturas (uma fratura de coroa e cinco fraturas de raiz mais pino). A taxa de sobrevivência de dentes restaurados com pinos de zircônia foi significantemente menor que nos outros grupos. Todos os grupos mostraram taxa de sobrevivência maior que a do grupo controle, indicando ser necessário um suporte para o material de reconstrução da porção coronária do núcleo quando toda a coroa dentária é perdida. Pinos de fibras reduziram significantemente o risco de fratura radicular, além de que as fraturas foram favoráveis à manutenção da raiz (ocorreram na altura em que estaria a gengiva marginal). $\mathrm{O}$ alto módulo de elasticidade do dióxido de zircônia em relação à dentina foi provavelmente a principal causa de seu maior índice de fratura. O comportamento mecânico dos pinos de fibras estéticas foi similar ao dos pinos de fibras de carbono convencionais.

Em 1999, RUDO; KARBHARI ${ }^{101}$ dissertaram sobre o comportamento mecânico das fibras de polietileno. Relataram que desde 1991 a fibra de polietileno Ribbond tem sido utilizada com sucesso. A adição destas fibras ao polimetilmetacrilato e à resina composta aumenta significantemente sua resistência à compressão e à fratura. As principais propriedades destas fibras seriam: (1) alta resistência à tração; (2) alto módulo de elasticidade; (3) absorção de água menor que 1\%; (4) quimicamente inertes a quase todos os solventes, ácidos ou substâncias alcalinas; (5) altamente biocompatíveis; (6) facilmente conformáveis e virtualmente livres de memória; (7) opticamente transparentes quando embebidas em resina (assumem a cor da resina). O Ribbond possui configuração entrelaçada especial, pois além das fibras paralelas há fibras que correm perpendicularmente e que passam entre os nós das fibras paralelas, unindo-as firmemente (dificultam seu desfiamento e também seu deslizamento dentro da matriz resinosa). Entre as fibras há suficiente 
espaço para permitir adequada impregnação pelo adesivo. As fibras de polietileno hidrofóbicas são convertidas em material hidrofílico pelo tratamento químico por plasma de gás oxigênio frio, aumentando a impregnação das fibras pela resina. O gás parcialmente ionizado age através de ablação e ativação. O processo de ablação funciona de forma similar ao condicionamento ácido (por remoção). A ativação é observada pela presença de grupos funcionais $\mathrm{O}-\mathrm{C}=\mathrm{O}$ na superfície das fibras. Assim, o mecanismo pelo qual o tratamento com plasma aumenta a resistência adesiva entre as fibras e a resina é a união química. As fibras devem ser impregnadas com adesivo de esmalte sem carga, que penetra nas fibras segundos após aplicado. Devem ser evitados adesivos com carga, pois são viscosos (de difícil penetração nas fibras, havendo impregnação insuficiente). Se manipulados para penetrar nas fibras, bolhas de ar são incorporadas com o adesivo e a impregnação também é incompleta.

Em 1999, ZANUTTO et al. ${ }^{134}$ sugeriram a utilização de núcleos dentários ou biológicos, que podem ser confeccionados a partir de (1) microdentes; (2) dentes extranumerários; (3) incisivos centrais e laterais inferiores permanentes; ou (4) dentes decíduos (centrais, laterais e caninos) com raiz. Por ser uma técnica nova, ainda necessita de avaliação clínica longitudinal. O conduto deve estar adequadamente tratado antes de aplicar a técnica, pois a remoção deste pino é difícil. É indicada principamente para dentes de pacientes jovens, com destruição coronária extensa. A técnica possui vantagens como: dispensa fase laboratorial (pode ser executada em sessão única); o estresse é dissipado em estruturas com propriedades semelhantes, proporcionando o equilíbrio de um dente normal; maior retenção do núcleo (adesão da resina à estrutura dentária); vantagem psicológica (não é uma prótese). Recomendaram a seguinte técnica: (1) remoção da obturação radicular até metade do conduto, seguida por leve alargamento e regularização do canal; (2) autoclavagem, limpeza do conduto do dente a ser utilizado como pino com broca Gates-Glidden introduzida por apical (para manter a coroa íntegra) e preenchimento do conduto com ionômero de vidro injetado por seringa Centrix ou lentulo; (3) remoção do cemento radicular para expor a dentina; (4) adaptação do pino ao conduto, mantendo o esmalte do pino exposto; (4) cimentação com cimento resinoso dual e sistema adesivo hidrofílico; (5) reconstrução da coroa com resina composta (cuja adesão ao pino é excelente, além de minimizar-se a quantidade de resina 
utilizada); (6) acabamento e polimento. Descreveram um caso clínico realizado em um incisivo central superior com a coroa ausente, em um paciente com 18 anos de idade. Um microdente serviu como pino biológico, a partir do qual a coroa foi reconstruída.

SIRIMAI; RIIS; MORGANO ${ }^{112}$, em 1999, avaliaram a resistência à fratura e incidência de fratura vertical em raízes tratadas endodonticamente e restauradas com seis diferentes sistemas de núcleos. Sessenta incisivos centrais superiores tiveram os condutos obturados e seqüencialmente alargados até $1,6 \mathrm{~mm}$ de diâmetro. A coroa dentária foi removida ao nível da junção cemento-esmalte. As raízes foram envolvidas em uma fina camada de silicona de adição (simulação do ligamento periodontal) e fixadas em blocos de resina acrílica. Formaram-se seis grupos, cada um com dez espécimes: Grupo 1 - núcleos metálicos fundidos (pratapaládio), cimentados com fosfato de zinco; Grupo 2 - pinos de titânio Vario-Passive com 1,6mm de diâmetro, de paredes paralelas e superfície serrilhada, cimentados com fosfato de zinco; neste grupo, assim como nos grupos 3 a 6, a porção coronária do núcleo foi construída com resina composta dual para núcleos Magnacore, associada a condicionamento com ácido fosfórico a 37\% e sistema adesivo Syntac; Grupo 3 - núcleos confeccionados com fibras de polietileno Ribbond (2mm de largura) e resina Heliobond; neste grupo, bem como nos grupos 4 e 5, foi utilizado para cimentação o cimento resinoso dual Variolink; $3 \mathrm{~mm}$ de fita foram mantidos fora do conduto para suporte da porção coronária do núcleo; Grupo 4 - núcleo confeccionado com pino de titânio puro Vario-Passive com diâmetro de 1,2mm envolvido por Ribbond; Grupo 5 - núcleo confeccionado com pino de liga de titânio de 1,25mm Para-Post Plus if 5 envolvido por Ribbond; Grupo 6 - pino Para-Post Plus $n^{\circ}$ 5. A carga de compressão foi aplicada em ângulo de $130^{\circ}$ ao longo eixo do dente na máquina de ensaios universal, à velocidade de $0,5 \mathrm{~mm} / \mathrm{min}$ e com célula de força de 100kg. Os resultados estão descritos na Tabela 2.3. 
TABELA 2.3 - Médias de resistência à fratura e desvios padrão para cada grupo experimental (SIRIMAI; RIIS; MORGANO, 1999)

\begin{tabular}{c|c} 
Grupo experimental & Limiar de carga para falha (kgf) \\
\hline Grupo 1 & $29,43 \pm 51,74$ \\
\hline Grupo 2 & $25,97 \pm 55,66$ \\
\hline Grupo 3 & $12,95 \pm 26,85$ \\
\hline Grupo 4 & $22,26 \pm 20,48$ \\
\hline Grupo 5 & $23,82 \pm 42,92$ \\
\hline Grupo 6 & $20,53 \pm 29,10$
\end{tabular}

Todas as falhas no grupo 1 (núcleos metálicos fundidos) envolveram fratura dentária, enquanto que $70 \%$ dos dentes com pinos pré-fabricados de paredes paralelas (grupo 2) falharam devido à fratura dos dentes e $30 \%$ devido à fratura da porção coronária. No grupo 3 (núcleo de Ribbond sem pino metálico), a resistência à fratura foi significantemente menor que nos demais grupos, porém houve um número significantemente menor de fraturas radiculares (somente uma fratura vertical da raiz e uma fratura horizontal no terço cervical da raiz); nos demais espécimes, houve somente fratura ou deslocamento da porção coronária do núcleo. Envolvimento com Ribbond e resina composta dos pinos metálicos de diâmetro menor que o do conduto (grupos 4 e 5) aumentou a resistência em relação à utilização destes pinos isoladamente (grupo 6) e também em relação à utilização das fibras de polietileno sem pino metálico (grupo 3), além de serem evidenciadas menos fraturas radiculares que com núcleos metálicos fundidos (grupo 1); a resistência, porém, manteve-se menor que a do grupo 1 e similar à do grupo 2 .

PEREIRA; SOUZA; PAULILLO ${ }^{90}$, em 1999, relataram caso clínico de utilização de núcleos de Ribbond em paciente jovem. No dente 12, foram desobturados $4 \mathrm{~mm}$ do conduto com brocas Largo, seguindo-se seu condicionamento ácido e aplicação do sistema adesivo. Após inserção de resina composta no conduto, foi condensada em seu interior a fita de polietileno impregnada em adesivo. O conjunto foi fotopolimerizado, mantendo-se pequena porção da fita externamente ao 
canal para retenção da coroa de resina composta a ser posteriormente construída. O acabamento foi executado de forma convencional. O dente 22 foi restaurado de forma similar.

Em 1999, BATISTA; LOPES $^{11}$ afirmaram que dentes com rizogênese incompleta e tratamento endodôntico são mais frágeis e predispostos à fratura, por possuírem o conduto muito amplo e paredes radiculares finas. Sugeriram a utilização de pinos dentários para restaurar condutos extremamente alargados de dentes com pouca estrutura coronária remanescente. Apresentaram dois casos clínicos com pinos obtidos a partir de dentes naturais e cimentados com técnicas adesivas. Os condutos foram parcialmente desobturados (até $4 \mathrm{~mm}$ do ápice). Os dentes naturais utilizados foram pré-molares, inicialmente descontaminados em hipoclorito de sódio a $1 \%$ por 30 minutos, hidratados por 72 horas e então autoclavados. Os dentes foram desgastados com discos de carborundum e brocas diamantadas até adequada adaptação nos condutos. No primeiro pino, o desgaste não atingiu o conduto, enquanto que no segundo o conduto ficou contido em seu interior. Neste último, o conduto foi ampliado com alargadores para permitir escape do cimento. Foi mantida uma extensão coronária para reforço e suporte do núcleo de preenchimento. Após condicionamento ácido dos pinos e do conduto radicular, foi aplicado o agente de união e executada cimentação com cimento resinoso. A porção coronária foi construída com resina composta híbrida. Os autores concluíram que a utilização de pinos dentários como reforço coronorradicular em dentes frágeis e com canais volumosos fornece vantagens como: (1) Adaptação à configuração do conduto, favorecendo maior resistência do dente e melhor retenção do pino em relação aos pinos pré-fabricados; (2) Adequada distribuição das forças longitudinais ao longo da raiz, gerando menor concentração de estresse; (3) Resiliência comparável àquela do dente; (4) Excelente adesão à estrutura dental e à resina composta; (5) Translucidez (melhor estética que pinos metálicos); (6) Confecção imediata (uma sessão). Os autores recomendaram que fossem melhor pesquisadas as propriedades mecânicas dos pinos dentários.

Em 1999, SOARES ${ }^{113}$ comparou a resistência à fratura de raízes hígidas restauradas com núcleo metálico fundido com a resistência de raízes 
debilitadas reconstruídas com três sistemas restauradores adesivos e núcleo metálico fundido. Utilizou 56 incisivos centrais e caninos superiores, divididos em quatro grupos: 1) raiz hígida com núcleo metálico fundido (controle); 2) raiz debilitada restaurada com resina composta fotopolimerizável Z100; 3) raiz debilitada restaurada com cimento de ionômero de vidro Vitremer; 4) raiz debilitada restaurada com resina composta autopolimerizável Bisfil II. As coroas foram removidas (padronizando-se os remanescentes radiculares com $12 \mathrm{~mm}$ de comprimento) e os condutos obturados. Um desgaste interno padronizado simulou enfraquecimento das raízes, mantendo-se espessura de $0,5 \mathrm{~mm}$ das paredes radiculares no terço cervical. As raízes foram preenchidas internamente, utilizando-se pino fototransmissor Luminex para auxiliar na fotopolimerização. Manteve-se profundidade de $8 \mathrm{~mm}$ de comprimento e $1,5 \mathrm{~mm}$ de diâmetro para o núcleo metálico fundido. No grupo controle, utilizou-se o alargador $n^{0} 4$ do sistema Luminex para preparo do conduto. As raízes foram fixadas em blocos acrílicos, os núcleos cimentados com fosfato de zinco e os espécimes armazenados por 24 horas em água deionizada à temperatura ambiente. Uma carga de compressão foi aplicada na máquina de ensaios universal, na face palatina do núcleo, em ângulo de $45^{0}$ com o plano horizontal. Em ordem decrescente, os sistemas mais resistentes à fratura foram: grupo 1, grupo 2, grupo 4 e grupo 3. Não houve diferença estatisticamente significante entre as resinas Z100 e Bisfil II. O ionômero de vidro Vitremer apresentou a menor resistência, apresentando diferença estatisticamente significante em relação aos demais grupos. Nenhum dos três sistemas adesivos recuperou a resistência à fratura original da raiz. Nas raízes debilitadas, todos os espécimes fraturaram, enquanto no grupo controle fraturaram $78,6 \%$ das raízes.

Um caso de colagem heterógena de fragmento dental coronorradicular (núcleo biológico) foi descrito em 1999 por CÂNDIDO; POZZOBON; PORTO NETO. Os autores ressaltaram que, apesar das melhorias nos materiais restauradores atuais, nenhum supera as propriedades da estrutura dental, a qual, quando possível, deve ser a alternativa de escolha. A técnica é ideal para reforço de dentes anteriores fragilizados por excessivo alargamento do conduto durante tratamento endodôntico. O paciente apresentava o dente 21 com perda parcial de estrutura coronária e excessivo alargamento do conduto. $\mathrm{O}$ pino foi confeccionado a partir do ajuste de um 
dente natural obtido em banco de dentes. Após remoção de dois terços da obturação radicular, executou-se uma moldagem com silicona de adição da região anterior, obtendo-se um modelo de gesso-pedra sobre o qual selecionou-se o dente. A polpa foi removida com instrumentos endodônticos e o conduto preenchido com resina composta fotopolimerizável. O ajuste do dente foi feito pela técnica da grafitagem - o interior do conduto no modelo é grafitado com lápis, o dente é encaixado neste local, e onde ficam marcas de grafite na raiz, a mesma é desgastada com pontas diamantadas até adequada adaptação do dente ao modelo. Na sessão seguinte, o pino foi provado em boca e cimentado. O dente e o pino receberam condicionamento ácido e sistema adesivo. Cimento resinoso dual foi utilizado para cimentação. Resina composta fotopolimerizável foi empregada para reconstituir a porção coronária e executar uma faceta direta. O pino dentário favorece a adesão do material restaurador. Os autores concluíram que a técnica reconstituiu forma, função e estética dental, com procedimentos de fácil acesso e execução, além de custo extremamente reduzido.

A restauração de dentes tratados endodonticamente com fibras de polietileno Ribbond foi discutida por ÍÑIGUEZ ${ }^{56}$, em 2000. Esta restauração, além de fornecer retenção para a coroa, também reforça esses dentes, pois é constituída por elementos quimicamente adesivos entre si e com propriedades similares (estrutura dentária, fibras e resina composta), resultando em um bloco sólido e com reflexão da luz idêntica à de um dente natural. A técnica é simples e econômica. A propagação de fraturas verticais é virtualmente eliminada. Esta restauração é especialmente indicada para dentes tratados endodonticamente que não necessitam de núcleos (quando há 50\% de dentina em dentes anteriores ou 30\% em dentes posteriores, além de haver pelo menos $2 \mathrm{~mm}$ de estrutura dentária natural). Descreveu a seguinte técnica: desobturação do terço cervical do conduto, limpeza com clorexidina e álcool $75 \%$ e isolamento do material obturador com $1 \mathrm{~mm}$ de fosfato de zinco aplicado com seringa Centrix. Normalmente utilizam-se fitas de Ribbond com $2 \mathrm{~mm}$ de largura. Mede-se a profundidade do conduto e corta-se a fita com o triplo dessa medida. Cobre-se a fita com adesivo, mantendo-a protegida da luz. Executa-se condicionamento ácido do conduto, aplica-se sistema adesivo dual e injeta-se no conduto cimento resinoso também dual. A fita de Ribbond é condensada no conduto, 
injeta-se mais cimento resinoso e, se o espaço permitir, insere-se no conduto outra fita, perpendicular à primeira, agregando-se mais cimento. As pontas que emergem do conduto são dobradas sobre si mesmas e também condensadas no conduto. Acrescenta-se mais cimento e polimeriza-se o conjunto. $\mathrm{O}$ autor utilizou a técnica em cerca de 500 casos, com poucos fracassos, atribuídos a erros na técnica de adesão.

GALINDO et al. ${ }^{43}$, em 2000, abordou a utilização de pinos naturais para reabilitar dentes decíduos anteriores. As vantagens seriam: tempo reduzido de confecção (em relação à reconstrução direta com resina composta); ausência de fase laboratorial (menor custo); ótimo desempenho clínico em relação à fratura, alteração de cor e saúde periodontal; perfeita adaptação ao conduto (melhor retenção mecânica e evita estresse sobre a dentina); técnica conservadora (não necessita desgaste adicional para retenção). As dificuldades seriam: aceitação dos pais (muitas vezes difícil), montagem do banco de dentes e o ajuste dos pinos, que pode ser trabalhoso. Apresentaram o caso de uma criança que necessitava restauração dos quatro incisivos superiores decíduos, devido à extensa destruição cariosa. Os pinos biológicos foram confeccionados a partir de dentes decíduos obtidos em banco de dentes. As raízes foram divididas em duas partes e desgastadas nas faces voltadas para o conduto, de forma que cada pino ficou recoberto parte por esmalte e parte por dentina ou cemento. $\mathrm{O}$ conduto foi desobturado até o terço médio com broca esférica de baixa rotação e colher de dentina. O material obturador foi recoberto com hidróxido de cálcio. Os pinos foram ajustados por desgaste com ponta diamantada cilíndrica de extremo arredondado. A porção coronária deve ser de, no mínimo, metade da altura da coroa dentária. $\mathrm{O}$ pino foi autoclavado $\left(15\right.$ minutos a $\left.120^{\circ} \mathrm{C}\right)$ e cimentado com ionômero de vidro modificado por resina, que possuiria vantagens como: adesividade ao pino e às paredes radiculares, compatibilidade biológica (permite reabsorção radicular), coeficiente de expansão térmica linear próximo ao da estrutura dentária e liberação de fluoretos. Sobre os pinos, foram cimentadas coroas confeccionadas com dentes naturais.

Em 2000, XIBLE $^{133}$ comparou a resistência adesiva ao cisalhamento de três sistemas de núcleos intra-radiculares. Utilizou pinos de cerâmica à base de dióxido de zircônia (Cosmopost) e pinos de titânio (Tenax). Os materiais de 
preenchimento coronário foram resina composta fotopolimerizável (Tetric Ceram) e porcelana vítrea fundível (IPS Empress Post). Foram confeccionados 30 espécimes divididos em três grupos (dez espécimes em cada grupo): 1) pinos de cerâmica aos quais foi fundida porcelana vítrea; 2) pinos de cerâmica e resina composta fotopolimerizável); e 3) pinos de titânio e resina composta fotopolimerizável. Os espécimes foram submetidos à forças de cisalhamento em máquina universal de ensaios até a fratura. $\mathrm{O}$ autor concluiu que o grupo 3 foi o que apresentou os maiores valores numéricos de resistência adesiva, porém sem diferença estatisticamente significante com o grupo 1 . Os grupos 1 e 3 apresentaram diferença estatisticamente significante em relação ao grupo 2, que apresentou os menores valores de adesão.

O'KEEFE; MILLER; POWERS ${ }^{88}$ mediram, em 2000, a resistência adesiva de pinos de quatro diferentes materiais (aço inoxidável, fibras de carbono, titânio e dióxido de zircônia) a três cimentos resinosos diferentes (Panavia 21, C \& B Metabond e Bis-Core). O pino de fibras de carbono utilizado foi o C-Post; duas marcas de pinos cerâmicos foram utilizados, Cosmopost e Cerapost; os pinos metálicos eram protótipos. Cada uma das cinco marcas comerciais de pinos foi dividida em três grupos (um para cada cimento) de cinco espécimes cada. Foram confeccionados discos a partir dos pinos, que sofreram o seguinte tratamento: polimento, abrasão com partículas de óxido de alumínio de 50ì e limpeza ultra sônica. A superfície dos discos cerâmicos foi ainda tratada com ácido hidrofluorídrico a $8 \%$ e silanizada. Cones de cimento com $3 \mathrm{~mm}$ de diâmetro e $5 \mathrm{~mm}$ de altura foram aplicados aos discos e o conjunto armazenado em umidificador a $37^{\circ} \mathrm{C}$ por 24 horas. Os corpos de prova foram submetidos à tração à velocidade de $0,5 \mathrm{~mm} / \mathrm{min}$ em máquina de ensaios universal até o deslocamento. A maior resistência adesiva foi obtida com Panavia 21 para todos os pinos, variando de 22MPa (dióxido de zircônia) até 37MPa (titânio). O C \& B Metabond ficou em segundo lugar, com adesão significantemente maior para aço inoxidável (16MPa) e titânio (22MPa) e valor mais baixo para dióxido de zircônia (8MPa). Os resultados mais baixos foram obtidos com Bis-Core, variando de 16MPa (aço inoxidável) a $8 \mathrm{MPa}$ (dióxido de zircônia). Na maioria dos casos, a adesão aos pinos de fibra de carbono foi menor que ao aço inoxidável e ao titânio, mas maior que ao dióxido de zircônia (menores valores de resistência adesiva). Quanto mais alta a resistência 
adesiva mais alta a porcentagem de falhas coesivas dentro do cimento; falhas adesivas ocorreram mais, respectivamente, com Bis-Core e todos os pinos, seguidos de C \& B Metabond e dióxido de zircônia e finalmente Panavia 21 com pinos de fibras de carbono.

GLAZER $^{44}$, em 2000, relatou um estudo para avaliar clinicamente pinos de fibras de carbono (Composipost $n^{\circ} 1$ e $n^{0} 2$ e Endopost $n^{0} 90$ e $n^{0} 100$ ) cimentados em 52 dentes (71,2\% inferiores e 28,8\% superiores), sendo 30,8\% incisivos, $25 \%$ caninos e $44,2 \%$ pré-molares. Todos os dentes tinham menos de $50 \%$ da estrutura coronária. Coroas unitárias englobaram 51,9\% da amostra e retentores de próteses parciais fixas $48,1 \%$ da mesma. Foi utilizado cimento resinoso e a porção coronária do núcleo foi construída com resina composta dual. Os dentes receberam coroas metalo-cerâmicas e acompanhamento de 6,7 a 45,4 meses (média de 28 meses). A taxa de sobrevivência foi de 89,6\%. Falhas ocorreram em três dentes com coroas unitárias e um retentor de prótese parcial fixa (dois pré-molares inferiores, um pré-molar superior e um canino superior). Duas falhas foram biológicas (patologia periapical) e duas mecânicas (um deslocamento de coroa e um deslocamento de núcleo), nenhuma delas comprometendo o elemento dentário. $\mathrm{O}$ achado mais significante foi que os pinos nos pré-molares inferiores apresentaram maior risco de falhas. O autor concluiu que pinos de fibras de carbono estão entre os mais previsíveis atualmente e que sua utilização em dentes anteriores superiores está associada com alto padrão de sucesso.

De acordo com FREILICH et al. ${ }^{41}$, em 2000, compósitos odontológicos reforçados com fibras são formados por pelo menos dois componentes: (1) componente de reforço (normalmente fibras de vidro, polietileno ou carbono), que fornece resistência e rigidez, e (2) matriz resinosa ou polimérica, que suporta o reforço e fornece ao material características de manipulação adequada. As fibras podem ser arranjadas em configurações unidirecionais (longas, contínuas e paralelas), trançadas ou entrelaçadas. Compósitos reforçados por fibras são materiais anisotrópicos, isto é, reagem de forma diferente de acordo com a direção da carga. Suas propriedades são melhores quando as fibras estão organizadas paralelamente com a direção do estresse mais alto recebido pela estrutura. É aconselhável um alto 
volume de fibras para obtenção de módulo de elasticidade suficientemente elevado para suportar as estruturas aplicadas sobre os compósitos reforçados por fibras. Porém, o volume de fibras não deve ser excessivo, pois impediria sua impregnação completa pela resina. Uma quantidade adequada de fibras na resina parece ser pouco menos que $50 \%$ do volume total. Fibras de polietileno entrelaçadas são as mais fáceis de manipular, devido ao arranjo e ao baixo módulo de elasticidade da fibra sob compressão. Pinos intra-radiculares confeccionados com fibras podem ser préfabricados em fibras de carbono (por exemplo, C-Post, U.M. C-Post, Aestheti-Post) ou em fibras de vidro (por exemplo, FibreKor Post) e ainda executados diretamente sobre o remanescente dentário com fibras não impregnadas de polietileno (por exemplo, Ribbond, Connect) ou de fibra de vidro (por exemplo, GlasSpan). Descreveu a seguinte técnica para confecção de pinos com fibras de polietileno: remoção parcial da obturação radicular (manter 4 a $5 \mathrm{~mm}$ no ápice), não sendo preciso alargar ou alterar a forma do conduto. Cortam-se fitas de polietileno com mais de duas vezes o comprimento do conduto. Dobram-se as fitas ao meio em forma de letra "V". Saturam-se as fibras com adesivo. Após o condicionamento ácido, lavase e aplica-se sistema adesivo hidrofílico no conduto e remanescente dentário. Aplica-se cimento resinoso autopolimerizável ou dual às paredes do conduto. Levase a fibra ao conduto, mantendo uma porção para fora do canal. Condensam-se fibras de polietileno no conduto até seu preenchimento completo. Aplica-se resina composta híbrida sobre as extensões coronárias das fibras para construir a porção coronária do núcleo.

RAMIRES-ROMITO et al. ${ }^{94}$, em 2000, relataram a utilização de dentes decíduos de banco de dentes para obtenção de restaurações biológicas visando solucionar um caso de cáries rampantes em uma criança. Os incisivos superiores decíduos, severamente destruídos, foram tratados endodonticamente e tiveram seus condutos preparados para receber pinos dentários. Os condutos e pinos receberam condicionamento com ácido fosfórico a $37 \%$ e adesivo hidrofílico. Os pinos foram cimentados e tiveram sua porção interna preenchida com cimento de ionômero de vidro modificado por resina. Preparos não-retentivos foram feitos sobre os pinos. Um término gengival em ombro foi executado e os ângulos vivos eliminados. Foi executada moldagem dos preparos com silicona para seleção de coroas naturais do 
banco de dentes. Após esterilização em autoclave, as coroas preparadas foram cimentadas com cimento resinoso dual. As coroas foram ajustadas e polidas com pontas diamantadas e discos de polimento para resina composta. Os autores concluíram que a "técnica biológica" é promissora, pois é simples, efetiva e restabelece adequadamente a função, sendo uma alternativa à restauração protética convencional.

Um caso clínico de confecção de núcleo com fibras de polietileno Ribbond associadas a um pino de fibra de vidro foi apresentado por KIMMEL ${ }^{63}$, em 2000. O autor afirmou que para dentes com canais excessivamente alargados são contra-indicados núcleos metálicos fundidos, pois a concentração de estresse no interior da raiz e o efeito de cunha podem gerar fratura radicular. Pinos préfabricados, apesar de possuírem diâmetros variados, normalmente adaptam-se razoavelmente bem somente no terço apical do conduto, mas mostram má-adaptação no terço cervical, dependendo de grande quantidade de cimento ou resina composta para retenção e suporte. As fibras de polietileno Ribbond são biocompatíveis e translúcidas. Sua arquitetura entrelaçada lhes fornece ótima flexibilidade e as torna virtualmente livres de memória elástica. O tratamento superficial com plasma permite baixo ângulo de contato entre a fibra e o adesivo, aumentando o "molhamento" da fibra e favorecendo a incorporação química da fibra à resina composta. Para reforço de dentes despolpados com canais alargados por cáries, por instrumentação agressiva do conduto ou por outro motivo, o autor recomendou a técnica a seguir. Inicialmente é feita a desobturação parcial do conduto, removendo o mínimo de estrutura dentária hígida possível. A embocadura do conduto é arredondada para melhor assentamento da fita e pino pré-fabricado, sem formação de espaços vazios. Uma radiografia periapical é obtida para seleção adequada do pino de fibra de vidro, levando-se também em conta que a espessura média do Ribbond é $0,33 \mathrm{~mm}$. O remanescente dentário é tratado com o sistema adesivo. O Ribbond impregnado com adesivo e coberto com cimento de presa química ou dual é levado ao conduto. Com um condensador endodôntico adaptado, o Ribbond é compactado verticalmente até a porção apical do conduto e lateralmente em direção às paredes do canal. A seguir, o pino de fibra de vidro FibreKor jateado com óxido de alumínio é coberto com cimento e inserido entre as fibras. Antes da polimerização total, a resina 
composta híbrida é comprimida no conduto e ao redor do pino, bem como entre as fitas que se projetam para fora do conduto, formando assim a base do núcleo. O conjunto é fotopolimerizado e pode-se executar o preparo para coroa total.

Ainda no ano de 2000, KIMMEL ${ }^{64}$, dissertando sobre a utilização de fibras de polietileno para confecção de núcleos de preenchimento, destacou que a técnica exige mínima remoção da estrutura dentária remanescente e proporciona um pino que fornece suporte e reforço interno da raiz, possibilitando o aproveitamento de raízes com paredes finas. A união química entre as paredes internas do preparo e os materiais restauradores cria um monobloco adesivo estável, que poderia deter trincas e microfraturas já existentes, prevenindo sua extensão até o periodonto.

POZZOBON; BANDEIRA; CASTRO ${ }^{91}$, em 2000, apresentaram a técnica de "overlay natural" para restaurar biologicamente dentes posteriores extensamente destruídos, através da colagem de fragmento total da porção oclusal de um dente. Apesar dos avanços dos materiais restauradores, nenhum reúne todas as propriedades ideais de modo que possam ser considerados substitutos completos da estrutura perdida. A técnica possui ótima relação custo-benefício. O paciente e/ou responsável devem ser esclarecidos acerca da origem do fragmento e dos mé todos de desinfecção e esterilização, que garantem a segurança biológica do procedimento. Um termo de orientação e aceitação deve ser assinado antes de iniciar o tratamento. O doador também deve dar seu consentimento, após esclarecido do destino que terão seus dentes. Alguns pacientes possuem ainda certo preconceito em doar ou receber fragmentos dentais. Isto ocorre por falta de esclarecimento de como o procedimento é executado e das vantagens proporcionadas. No caso descrito, um paciente com 13 anos de idade apresentava o dente 26 com extensa destruição cariosa. Um pino metálico pré-fabricado foi cimentado no canal palatino e o dente foi preenchido com ionômero de vidro modificado, confeccionando-se um platô até a altura da relação de contato, para facilitar a seleção, adaptação e colagem do fragmento. Procedeu-se à moldagem das arcadas, registro intermaxilar e montagem dos modelos obtidos em um oclusor. Após medição das dimensões do preparo, um dente com tamanho e forma equivalentes foi selecionado do banco de dentes. A face oclusal do dente selecionado foi recortada e ajustada sobre o modelo. $\mathrm{O}$ fragmento foi esterilizado em 
autoclave a $121^{\circ} \mathrm{C}$ por 15 min. Na segunda sessão, após isolamento absoluto e précunhamento para obtenção de leve afastamento, o fragmento foi provado. Sobre o remanescente foram confeccionadas retenções adicionais ("pins" e canaletas). $\mathrm{Na}$ seqüência, foram realizados no remanescente e no fragmento condicionamento ácido, aplicação de sistema adesivo, cimentação com cimento resinoso de presa dual e ajuste oclusal.

BONILLA $^{12}$, em 2001, avaliou a resistência à fratura de raízes amplamente destruídas reconstruídas morfologicamente ou não com sistemas adesivos e restauradas com núcleos metálicos fundidos, bem como a resistência à fratura de raízes amplamente destruídas restauradas com pinos dentários. Quarenta caninos superiores foram igualmente divididos em quatro grupos: (1) raiz íntegra com núcleo metálico fundido; (2) raiz amplamente destruída com núcleo metálico fundido; (3) raiz amplamente destruída reconstruída com resina composta e núcleo metálico fundido; e (4) raiz amplamente destruída reconstruída com pino dentário. Removeram-se as coroas dentárias e os condutos foram obturados. No grupo 1, o conduto foi preparado para receber núcleo metálico fundido convencional. Nos grupos 2, 3 e 4, foi executada seqüência padronizada de desgaste para simular uma raiz amplamente destruída, com espessura de paredes de $0,5 \mathrm{~mm}$ no terço cervical. No grupo 2, foram confeccionados núcleos metálicos fundidos. No grupo 3, as raízes foram reconstruídas com resina composta fotopolimerizável para construção de núcleos Build-It!, polimerizada através de pino fototransmissor Luminex, criando um novo conduto que foi preparado para receber núcleo metálico fundido. O gupo 4 recebeu pinos dentários obtidos a partir de dentes naturais. As raízes foram incluídas em blocos acrílicos e os núcleos cimentados com cimento resinoso. Os espécimes foram armazenados por 24 horas em água deionizada à temperatura ambiente. Os testes de resistência à fratura foram feitos em máquina de ensaios universal, com compressão à velocidade de $0,5 \mathrm{~mm} / \mathrm{min}$, incidindo na porção palatina do núcleo, em ângulo de $135^{\circ}$ em relação ao longo eixo da raiz. A resistência à fratura sob compressão apresentou os seguintes valores, em ordem crescente: (1) Grupo 3 53,98kgf; (2) Grupo 2 - 57,64kgf; (3) Grupo 4 - 76,35kgf; e (4) Grupo 1 - 87,59kgf. Não houve diferença estatisticamente significante entre os grupos 1 e 4, nem entre os 
grupos 2 e 3 . Os valores encontrados para os grupos 2 e 3 foram $30 \%$ menores que os dos grupos 1 e 4 (diferença estatisticamente significante).

A utilização de pinos biológicos em uma criança com extensas lesões cariosas nos dentes anteriores decíduos foi relatada por SANTOS-PINTO et al. ${ }^{103}$, em 2001. Após tratamento endodôntico, foi removido o material obturador do terço cervical do conduto. Para retenção intracanal nos incisivos centrais superiores, confeccionaram-se pinos biológicos com raízes de dentes naturais, seccionadas com discos diamantados em seu longo eixo. Os pinos foram confeccionados sobre modelos que reproduziam os condutos. A moldagem foi executada com silicona de condensação e com auxílio de cunha de madeira de forma cônica no conduto. Para o desgaste dos pinos utilizou-se uma ponta diamantada tronco-cônica. Após a autoclavagem dos pinos em recipiente com água $\left(15\right.$ minutos a $\left.120^{\circ} \mathrm{C}\right)$, estes foram cimentados com cimento resinoso. A parte coronária do núcleo foi reconstruída com resina composta híbrida fotopolimerizável e as coroas foram confeccionadas em resina acrílica prensada. Os autores salientaram que a técnica torna as consultas mais curtas, embora aumente seu número por apresentar uma fase laboratorial.

SILVA E SOUZA JÚNIOR et al. ${ }^{107}$, em 2001, descreveram a confecção de núcleos com fibras de polietileno. O sistema Ribbond, constituído por fitas fornecidas em larguras de 1, 2, 3, 4 e 9mm, é um dos mais difundidos para reconstrução coronária de dentes desvitalizados. O fabricante originalmente indicava fitas de $1 \mathrm{~mm}$ para reforço intra-radicular, mas larguras maiores podem ser usadas de acordo com o diâmetro do conduto. Descreveram um caso clínico onde o dente 21 apresentava-se com destruição da maior parte da coroa. Desobturou-se parcialmente o conduto e a seguir executou-se apoio para o núcleo na embocadura do conduto, com broca diamantada esférica 1016, visando evitar rotação do pino. Seguiu-se condicionamento ácido do conduto e aplicação do sistema adesivo Scotchbond Multi-Uso Plus. Uma fita de Ribbond de $2 \mathrm{~mm}$ de largura também foi impregnada com adesivo; são desaconselháveis agentes de união associados ao "primer" (monocomponentes). O conduto foi preenchido por cimento resinoso dual. A fita é introduzida no conduto com instrumento próprio desenhado pelo fabricante ou com espátula Rhein (cuja ponta deve ser cortada). Após compactação da fita no conduto, 
buscando-se a melhor adaptação possível às suas paredes, corta-se o feixe de fibras ligeiramente acima do comprimento desejado para a porção coronária do núcleo. Prende-se a extremidade do feixe com porta-agulha e, com movimentos de rotação, a fita é enrolada até apresentar-se firme. Aplicou-se resina composta ao redor e entre o feixe de fibras para formar a porção coronária do núcleo.

Em 2001, FELIPPE et al. ${ }^{37}$ dissertaram sobre o emprego de fibras de reforço em odontologia. As fibras possuem alta resistência quando agrupadas em forma de fitas ou cordões. São leves e não oxidam. Seu propósito básico é reforçar grandes volumes de resina (composta ou acrílica), polímero ou cerômero. Auxiliam a distribuir e dissipar as forças na estrutura à qual foram incorporadas, diminuindo e homogeneizando o estresse. Se utilizadas para confecção de núcleos, conduziriam a luz do fotopolimerizador. As fibras mais utilizadas atualmente são as de vidro, polietileno, cerâmica e carbono. Fibras de vidro (por exemplo, GlasSpan) e de polietileno (por exemplo, Ribbond, Connect) possuem características clínicas similares e são as mais apropriadas para uso odontológico. Sua translucidez favorece a estética. O direcionamento ou arquitetura das fibras influi na resistência da estrutura reforçada. $O$ ideal seria a incorporação de fibras transversais e longitudinais, pois quanto mais paralela a disposição das fibras em relação às forças aplicadas sobre a estrutura, maior a absorção e dissipação de forças; assim, deve-se considerar que as forças atuam nos dentes tanto no sentido axial (paralelo ao longo eixo) quanto transversal (perpendicular ao longo eixo). O Ribbond consiste de fitas com fibras entrelaçadas tanto em direção longitudinal quanto transversal; já o Connect apresenta fios longitudinais trançados. A arquitetura também influencia na manipulação. Produtos com fios longitudinais desfiam facilmente, enquanto uma arquitetura entrelaçada evita desfiamento. A memória elástica dos fios (capacidade de voltar à posição original após a deflexão) também influencia na manipulação. Quando os fios possuem alta memória elástica, a inserção é difícil. Quanto maior a impregnação das fibras (união molecular entre fibras e matriz resinosa), maior a resistência. Em produtos pré-impregnados, a fibra já vem incorporada na matriz resinosa, permitindo maior rapidez de trabalho, fácil utilização e maior resistência final. Produtos não-impregnados (por exemplo, Ribbond) necessitam completo banho das fibras com adesivo antes do uso. Quantidade e distribuição das fibras 
influenciam também na resistência da estrutura. Um volume de $45 \%$ de fibras na estrutura é o suficiente; uma quantidade excessiva de fibras na matriz resinosa compromete o molhamento. A distribuição das fibras na estrutura deve ser o mais homogênea possível. A fibra também deve ficar totalmente coberta pela resina, pois se exposta ocorre acúmulo de placa, rápida pigmentação, degradação da resina por infiltração de líquidos, sensação desagradável do paciente ao tocar os fios da fibra e irritação gengival. Por isso, as fibras expostas são superficialmente removidas com pontas diamantadas, limpa-se com ácido fosfórico, seca-se, aplica-se adesivo, e cobre-se com nova camada de resina. A resina de escolha é a híbrida (mais resistente à fratura). Quando não há envolvimento estético, utilizam-se cores incisais (translúcidas) ou claras de resina, cuja polimerização é mais rápida e completa, além de permitir transmissão da luz através das fibras. A fibra selecionada deve ser a mais larga possível para melhor reforço. Para confecção de núcleos, geralmente utilizamse fitas com largura de $1 \mathrm{~mm}, 2 \mathrm{~mm}$ ou $3 \mathrm{~mm}$, dependendo da amplitude do conduto. A tesoura para corte da fibra deve ser serrilhada, pois os fios são resistentes ao corte e uma tesoura lisa tende a escorregar.

Um caso clínico no qual fibras de polietileno Ribbond foram empregadas para confecção de núcleo de preenchimento foi descrito por $\mathrm{KAKAR}^{59}$, em 2001. Um paciente com 15 anos de idade apresentou-se com incisivo central superior fraturado no terço gengival e exposição pulpar. Após tratamento endodôntico, desobturou-se o conduto até $12 \mathrm{~mm}$ a partir da borda incisal do remanescente dentário. Duas fitas de Ribbond ( $3 \mathrm{~mm}$ de largura) foram utilizadas, uma com $30 \mathrm{~mm}$ de comprimento e outra com $28 \mathrm{~mm}$. As fitas foram dobradas em sua porção média. O conduto e o remanescente dentário foram condicionados com ácido fosfórico e o sistema adesivo foi aplicado. Cimento resinoso dual foi inserido no conduto com a ponta agulha da seringa Centrix e aplicado sobre as fitas de Ribbond. As fitas dobradas foram conduzidas ao conduto com instrumento reto de ponta romba, a fita mais longa antes do que a mais curta. $\mathrm{O}$ conduto foi totalmente preenchido com Ribbond e quatro pontas da fita (com cerca de $3 \mathrm{~mm}$ cada) ficaram sobressaindo do conduto. As pontas (e o espaço entre elas) foram cobertas com o cimento extruído do conduto e com o cimento remanescente na ponta Centrix para modelar o núcleo. O conjunto foi fotopolimerizado e aguardou-se a presa do cimento 
resinoso. O núcleo foi preparado para receber uma coroa total. $\mathrm{O}$ autor lembrou que a confecção de núcleos metálicos fundidos envolve muitos passos laboratoriais intermediários que podem conduzir a erros. Núcleos fundidos, quando muito justos, podem causar efeito de cunha na raiz, e se muito frouxos deslocam-se facilmente. Os núcleos fibroresinosos permitem eliminar passos laboratoriais; todo o controle está nas mãos do cirurgião-dentista, que confecciona o núcleo diretamente na cavidade oral. Além disso, o núcleo é adesivo, criando um sistema do tipo monobloco com o remanescente dentário, o que favorece a transmissão de forças oclusais sobre a raiz. As fitas de Ribbond, após reforçadas com resina, são muito resistentes, e, por serem branco-opacas, tornam-se invisíveis na resina, não interferindo com a cor da coroa. As fitas são tratadas com plasma de oxigênio para aderirem a resinas sintéticas.

BOTTINO et al. ${ }^{14}$, em 2001, afirmaram que o objetivo principal da incorporação de fibras em trabalhos com resinas é aumentar sua resistência. Os compósitos mais recentes melhoraram suas propriedades mecânicas pela incorporação de elevada quantidade de fibras (alguns possuem até 40-45\% em volume de fibras). As fibras utilizadas com maior sucesso são as de vidro e as de polietileno. Fibras de polietileno possuem excelentes propriedades mecânicas para forças de tração, porém baixa resistência à compressão. As fibras odontológicas podem possuir diferentes arranjos: (1) unidirecional, (2) entrelaçada ou malha e (3) trançada. Produtos unidirecionais (fibras paralelas, dirigindo-se todas para uma mesma direção) possuem alta resistência flexural (importante para próteses fixas), mas durante a manipulação as fibras são espaçadas. Produtos trançados apresentam feixes de fibras emaranhadas como tranças de cabelo. Já produtos com padrões entrelaçados ou malha (por exemplo, Ribbond) possuem, além de fibras paralelas, outras que correm perpendicularmente. Materiais com fibras são anisotrópicos (propriedades variáveis de acordo com a direção da carga aplicada em relação à orientação da fibra). A resistência melhora com: (1) maior volume de fibras - porém, se em quantidade excessiva não são totalmente impregnadas pela resina; (2) distribuição uniforme de fibras na estrutura; (3) melhor incorporação da resina nas fibras. Todas as fibras precisam ser impregnadas por resina, mas alguns produtos são fornecidos pré-impregnados. As vantagens dos produtos pré-impregnados são: menor número de passos para o operador, melhores propriedades mecânicas, impregnação 
homogênea da resina e boa consistência de manipulação. A desvantagem é que a resina não pode ser selecionada. Quanto aos sistemas não impregnados, as desvantagens são: a impregnação total de todas as fibras é difícil, possível contaminação da superfície durante manipulação e maior tempo de trabalho. A vantagem é que o operador pode selecionar a resina. Na Figura 2.4 foram resumidas as características dos produtos com fibras de polietileno mais conhecidos.

\begin{tabular}{c|c|c|c|c|c} 
Produto & Fabricante & $\begin{array}{c}\text { Arquitetura } \\
\text { da fibra }\end{array}$ & $\begin{array}{c}\text { Resistência } \\
\text { flexural }\end{array}$ & $\begin{array}{c}\text { Facilidade } \\
\text { de } \\
\text { adaptação }\end{array}$ & Impregnação \\
\hline RIBBOND & Ribbond & Entrelaçada & Baixa & Muito alta & $\begin{array}{c}\text { Requer } \\
\text { impregnação }\end{array}$ \\
\hline CONNECT & Kerr & Trançada & Baixa & Alta & $\begin{array}{c}\text { Requer } \\
\text { impregnação }\end{array}$ \\
\hline DVA FIBERS & $\begin{array}{c}\text { Dental } \\
\text { Ventures }\end{array}$ & Unidirecional & Baixa & Alta & $\begin{array}{c}\text { Requer } \\
\text { impregnação }\end{array}$ \\
\hline $\begin{array}{c}\text { SPLINT-IT! } \\
\text { (possui versão } \\
\text { em fibra } \\
\text { de vidro) }\end{array}$ & $\begin{array}{c}\text { Jeneric/ } \\
\text { Pentron }\end{array}$ & Unidirecional & Alta & Média & $\begin{array}{c}\text { Pré- } \\
\text { impregnado }\end{array}$
\end{tabular}

FIGURA 2.4 - Quadro comparativo das características mais relevantes das principais fibras de polietileno atualmente comercializadas (BOTTINO et al., 2001)

Quanto às características clínicas das principais fibras de polietileno, os autores relataram que o Ribbond possui: (1) facilidade de corte com a tesoura apropriada; (2) fácil adaptação; (3) rápida incorporação na resina com ótima compatibilidade de cor; (4) adesividade adequada; (5) durabilidade; (6) menor índice de falhas quando comparado às ferulizações com fios ortodônticos. As fibras de polietileno Connect possuem: (1) adesividade adequada; (2) durabilidade; (3) menor índice de falhas em relação às ferulizações com fios ortodônticos; (4) pouca variedade de tamanhos das fitas; (5) as fibras se separam quando cortadas. Sobre o DVA Fibers destacaram que (1) deve ser cortado com tesoura cerâmica especial; (2) a impregnação das fibras com resina facilita o corte (alta tendência a desfiar se cortado sem estar impregnado). 
A reconstrução da morfologia interna de dentes endodonticamente tratados através de pinos fibroresinosos foi descrita por TERRY; TRIOLO ${ }^{123}$, em 2001. Os materiais utilizados, em conjunto, simulam as propriedades físicas do dente natural, criando um complexo restaurador que devolve função e estética. Tais materiais são: fibras de polietileno adesivas (Construct; Ribbond; Connect), agentes de união hidrofílicos, cimento resinoso híbrido de cura dual e resina composta híbrida de cura dual. As fibras hidrofóbicas são tratadas com plasma de gás frio, tornando-se hidrofílicas. Isto permite molhamento completo pelo adesivo, pois cria um baixo ângulo de contato; o aumento da área de superfície e dos grupos funcionais $\mathrm{O}-\mathrm{C}=\mathrm{O}$ permite adesão química entre as fibras e as resinas sintéticas. $\mathrm{O}$ reforço com fibras aumenta a resistência à tração. A arquitetura entrelaçada do Ribbond resiste melhor ao deslocamento sob tração que as demais fitas, minimizando a propagação de fraturas por coalescência de microtrincas dentro da matriz resinosa (o que levaria à falha de todo o complexo). As fibras auxiliam a redirecionar o estresse para o longo eixo da raiz. As vantagens são: flexibilidade das fibras; consulta única; não há custo laboratorial; fratura radicular improvável; é desnecessário preparo do conduto (técnica conservadora); melhor retenção devido ao aumento da superfície retentiva, resultante das irregularidades do conduto; ótima estética. As desvantagens são: técnica sensível (necessita cuidadoso protocolo adesivo) e necessidade de estocar os materiais utilizados. Observaram que a fita de polietileno Construct (Kerr), previamente impregnada com resina, pode ser manipulada com os dedos sem auxílio de luvas. Pelo que tudo indica até o momento, pinos fibroresinosos têm grande potencial para sucesso a longo prazo, porém mais pesquisas são necessárias para demonstrar sua efetividade.

Segundo STEWARDSON ${ }^{120}$, em 2001, as principais vantagens dos pinos não-metálicos são: (1) reduzido número de fraturas radiculares, sendo estas mais favoráveis quando ocorrem; (2) estética melhorada; (3) fácil remoção (exceto para pinos cerâmicos), existindo kits de remoção próprios para vários sistemas; (4) maior biocompatibilidade (ausência de corrosão, galvanismo e citotoxicidade); (5) formação de um complexo biomecânico único pela adesão entre estrutura dentária, agente cimentante e pino, reforçando assim a raiz. $\mathrm{O}$ autor classificou os pinos nãometálicos em pinos de materiais compósitos e pinos cerâmicos. Os compósitos, que 
devido à similaridade de seu módulo de elasticidade com o da dentina, funcionariam em harmonia com o dente, minimizando fraturas radiculares, podem classificar-se em: (1) pinos de fibras de carbono (Composipost, Endopost, Carbonite, Mirafit Carbon), que em versões atuais podem ser encontrados radiopacos ou mais estreitos; (2) pinos de fibras de vidro, geralmente quartzo ou sílica-zircônia em matriz resinosa (Aestheti-Post, Aestheti-Plus, Snowpost, Para-Post Fiber White, Glassix, Miraft White, Fibrekor, Style-Post), com propriedades físicas similares às dos pinos de fibras de carbono, mas estética melhorada; (3) pinos fototransmissores (Lightpost, Luscent Anchors), compostos por pinos de fibras de vidro translúcidas, visando a reconstituição de raízes com condutos excessivamente alargados e facilitar a polimerização de cimentos duais ou fotopolimerizáveis (ainda sem comprovação); (4) pinos de fibras de polietileno entrelaçadas (Ribbond), ainda com poucos estudos sobre sua resistência à fratura e capacidade de reforço radicular. Quanto aos pinos cerâmicos (Cosmopost, Cerapost), são os mais indicados com coroas de porcelana pura pela excelente estética, e possuem também alta resistência e dureza, bem como biocompatibilidade; com a adesão dos pinos cerâmicos ao remanescente dental, espera-se a recuperação da resistência original da raiz.

RAYGOT; CHAI; JAMESON ${ }^{97}$, em 2001, estudaram o modo de fratura inicial e a resistência à fratura de incisivos centrais superiores tratados endodonticamente e restaurados com núcleos metálicos fundidos, pinos préfabricados de aço inoxidável ou de fibras de carbono. Quando utilizaram-se pinos pré-fabricados, confeccionou-se a porção coronária com resina composta autopolimerizável. Coroas totais metálicas foram cimentadas com fosfato de zinco sobre os núcleos. Após armazenamento dos espécimes por 24 horas em água destilada, estes foram submetidos à carga compressiva em ângulo de $130^{\circ} \mathrm{em}$ relação ao longo eixo do dente, à velocidade de $25,4 \mathrm{~mm} / \mathrm{min}$. A carga foi programada para cessar ao primeiro sinal de fratura, permitindo melhor análise do modo de fratura do que em estudos nos quais o corpo de prova é totalmente destruído e várias falhas secundárias são geradas. Para detectar o modo inicial de falha, os dentes foram imersos em tinta preta por 12 horas e seccionados no sentido mésio-distal. A resistência à fratura foi similar entre os três pinos testados: $38,13 \mathrm{kgf}$ para núcleos metálicos fundidos, 31,3kgf para pinos de fibras de carbono e 31,1kgf 
para pinos de aço inoxidável. Em todos os espécimes, houve falhas adesivas entre núcleo e estrutura dentária e na margem da coroa, bem como fratura dentária - em qualquer dos grupos, entre 70 a $80 \%$ dos dentes mostraram fraturas acima do nível ósseo simulado. Não ocorreram falhas coesivas dos materiais restauradores.

STRUB; PONTIUS; KOUTAYAS ${ }^{121}$, em 2001, avaliaram a taxa de sobrevivência e a resistência à fratura de incisivos centrais superiores tratados endodonticamente e restaurados com diferentes sistemas de núcleos: (1) pino metálico contendo paládio (Permador) e porção coronária em liga metálica preciosa; (2) pino de dióxido de zircônia (Cerapost) com porção coronária em cerâmica préfabricada Procera (coping Ceracap); (3) pino experimental resinoso-cerâmico fresado em máquina Celay com porção coronária em cerâmica pré-fabricada Procera (coping Ceracap); (4) pino de dióxido de zircônia (Cerapost) com porção coronária em cerâmica fundida (Cosmo Ingots). Para a cimentação, utilizoutse fosfato de zinco no grupo 1 e cimento resinoso nos demais grupos. Os copings cerâmicos Ceracap (Procera) foram cimentados sobre os núcleos com cimento resinoso. As taxas de sobrevivência após exposição a 1,2 milhões de ciclos em boca artificial (equivalentes a cinco anos em ambiente oral) para os diferentes grupos foram: (1) 90\%; (2) 80\%; (3) 60\%; e (4) 100\%. Os espécimes remanescentes foram submetidos a cargas compressivas em ângulo de $135^{\circ}$ em relação ao seu longo eixo, à velocidade de $0,5 \mathrm{~mm} / \mathrm{min}$. As médias de resistência à fratura para os quatro grupos foram: (1) 129,5kgf; (2) 152,3kgf; (3) 116,9kgf; e (4) 47,2kgf. Houve diferenças significantes entre todos os grupos, com exceção dos grupos 1 e 2 e dos grupos 1 e 3 . Nenhum dos núcleos do grupo 4 fraturou durante o teste de fadiga; a resistência à fratura deste grupo foi menor que a dos demais (possivelmente devido a alterações internas da zircônia durante a fundição), porém manteve-se acima do nível clínico necessário.

BUTZ et al. $^{22}$, em 2001, compararam taxas de sobrevivência e resistência à fratura de incisivos centrais superiores tratados endodonticamente e restaurados com diferentes sistemas de pinos após exposição a cargas cíclicas: (1) pinos de titânio (ER Komet) com porção coronária em resina composta; (2) pinos de dióxido de zircônia (Cerapost) com porção coronária em resina composta; (3) pinos 
de dióxido de zircônia (Cerapost) com porção coronária em cerâmica termoprensada (Empress-Cosmo); (4) núcleos metálicos fundidos em ouro tipo III (controle). Cimentaram-se os pinos com cimento resinoso. Foram cimentadas coroas metálicas sobre os núcleos com ionômero de vidro. Manteve-se $2 \mathrm{~mm}$ de estrutura dentária para efeito férula. Os espécimes foram expostos a 1,2 milhões de ciclos em simulador de mastigação com termociclagem simultânea, sendo posteriormente os espécimes sobreviventes submetidos à carga compressiva em ângulo de $130^{\circ}$ ao longo eixo do dente e à velocidade de $1,5 \mathrm{~mm} / \mathrm{min}$. Os grupos 1,3 e 4 mostraram taxas de sobrevivência e resistência à fratura similares. As taxas de sobrevivência e médias de resistência à fratura foram, respectivamente: (1) $94 \%$ e 43,3kgf; (2) $63 \%$ e 20,5kgf; (3) $100 \%$ e 38,5kgf; (4) 94\% e 43,4kgf. Concluiu-se que pinos de zircônia associados à resina composta não são indicados para uso clínico, devido à taxa de sobrevivência e resistência à fratura baixas (diferença estatisticamente significante em relação aos demais grupos). Os grupos 1 e 4 apresentaram padrão similar de fraturas (geralmente oblíquas, no terço médio ou apical da raiz); nos grupos 2 e 3 houve menos fraturas desfavoráveis da raiz.

GUEDES $^{46}$, em 2002, descreveu o emprego de um pino biológico em um incisivo central superior decíduo de uma criança com extensa destruição cariosa dos dentes anteriores superiores decíduos. Recomendou que o pino não ultrapasse o terço médio da raiz, pois causaria sobrecarga e reabsorção patológica da raiz, que sofreria esfoliação precoce. A porção do pino que permanece externamente ao conduto deve corresponder à metade da altura da coroa dentária. Um incisivo de dimensão compatível foi selecionado de banco de dentes e adaptado por desgaste ao conduto do dente a restaurar. Após condicionamento ácido e aplicação do sistema adesivo no dente a restaurar e no pino, este foi cimentado com cimento resinoso dual. A seguir, o dente foi restaurado com resina composta fotopolimerizável.

ESKITAKIOĐLU; BELLI; KALKAN ${ }^{34}$, em 2002, compararam núcleos confeccionados com fibras de polietileno Ribbond e cimento resinoso dual Variolink 2 com núcleos metálicos fundidos, utilizando teste de resistência à fratura convencional e método do elemento finito (para análise do efeito da rigidez do núcleo na distribuição do estresse). Para o teste de resistência à fratura, dois grupos 
de incisivos centrais superiores humanos (dez dentes para cada sistema de núcleos) tiveram a coroa removida $1 \mathrm{~mm}$ acima da junção cemento-esmalte e foram endodonticamente tratados. Para confecção de núcleos com Ribbond, o remanescente dentário e o conduto foram condicionados com ácido fosfórico e então foi aplicado o sistema adesivo; duas fitas de Ribbond com $2 \mathrm{~mm}$ de largura, medindo o dobro da profundidade do conduto, que era de $8 \mathrm{~mm}$, adicionando-se 16 a 20mm, foram impregnadas com adesivo; o excesso de adesivo foi removido e as fitas dobradas em forma de letra "V"; na parte interna das fitas dobradas foi aplicado cimento resinoso dual. A primeira fita de Ribbond foi inserida no conduto e após esta uma segunda fita em orientação perpendicular à primeira. Uma porção adicional de cimento foi aplicada entre as fitas que emergiam do conduto e o conjunto foi fotopolimerizado. Os núcleos metálicos fundidos foram cimentados com fosfato de zinco. Os núcleos não foram recobertos com coroas totais. Os dentes foram fixados em blocos de resina acrílica. Armazenaram-se os espécimes em água por 24 horas antes do teste. Não houve diferença estatisticamente significante entre a resistência à fratura dos dois sistemas: 37,7kgf para núcleos metálicos fundidos e 33,4kgf para núcleos de fibras de polietileno. Para análise pelo método do elemento finito construíram-se pseudomodelos tridimensionais de incisivos centrais superiores restaurados com ambos os sistemas. Utilizourse uma carga de $200 \mathrm{~N}$ para simular forças mastigatórias. O método mostrou que ocorre maior concentração de estresse no interior (ao longo) dos núcleos metálicos fundidos, sendo baixa a transmissão de estresse para o dente e para as estruturas de suporte. Já com os núcleos fibroresinosos, o estresse foi mais transferido para o dente e as estruturas de suporte (especialmente na região do terço cervical), sendo acumulado menos estresse no próprio núcleo. No entanto, sete das dez raízes com núcleos metálicos fundidos fraturaram (geralmente no terço cervical), possivelmente devido ao deslocamento do pino (que ocorreu em todas as raízes) por falta de adesão. Com núcleos de Ribbond, somente duas raízes fraturaram; em sete delas fraturou a porção coronária do núcleo e em uma delas o pino deslocou.

A influência de sete sistemas adesivos nas propriedades de flexão de fibras de polietileno foram avaliadas por ELLAKWA et al. ${ }^{32}$, em 2002. Prepararamse nove grupos (grupos A até I) de barras utilizando resina composta indireta 
Solidex reforçada com fibras de polietileno não-impregnadas Connect ( $2 \mathrm{~mm}$ de largura), inseridas na base do molde. No grupo I reforçourse com fibras não impregnadas com adesivo. Um grupo adicional (grupo J) foi preparado somente com resina composta. Nas fibras de polietileno dos grupos A até $G$ utilizaram-se diferentes agentes adesivos; nos grupos $\mathrm{G}$ e $\mathrm{H}$ foi utilizado o mesmo adesivo, mas no grupo $\mathrm{H}$ as fibras foram silanizadas antes da aplicação do adesivo. Armazenaramse os corpos de prova em água destilada por 24 horas a $37^{\circ} \mathrm{C}$ antes de medir resistência à flexão e módulo de flexão (módulo de elasticidade) à velocidade de $1 \mathrm{~mm} / \mathrm{min}$. A microscopia eletrônica de varredura mostrou completa justaposição entre fibras impregnadas com adesivo e resina; com fibras não impregnadas, havia áreas de separação (gaps) na interface fibra-resina. Houve diferenças significantes na resistência à flexão entre os grupos impregnados pelos diversos adesivos, sendo a variação de 169 a 266MPa. A média mais alta foi observada usando-se adesivos com maior carga de partículas inorgânicas, provavelmente pelo menor grau de contração de polimerização (reduzindo falhas adesivas). Nos grupos reforçados, os fragmentos mantiveram-se unidos entre si, mas no grupo sem reforço, que obteve a menor resistência à flexão $(66 \mathrm{MPa})$, houve falhas catastróficas. A pré-silanização antes da impregnação com adesivo reduziu significantemente resistência à flexão (169MPa) e o módulo de flexão, possivelmente devido à influência negativa do silano sobre o tratamento superficial com plasma. Com fibras não impregnadas por adesivo houve baixa resistência à flexão (75MPa) e baixo módulo de flexão. Ressaltaram que uma adesão adequada das fibras à matriz resinosa é importante para otimizar sua resistência, pois aumenta o contato entre matriz e fibras e possibilita transferir o estresse da matriz para as fibras, maximizando o efeito de reforço. Como as fibras de polietileno são quimicamente inertes e têm baixa energia de superfície, recomendase seu tratamento superficial com plasma, que introduz na superfície grupos reativos contendo oxigênio. Concluiu-se que impregnação com adesivo afeta significantemente a resistência à flexão de fibras de polietileno. Um estudo adicional foi realizado para investigar a influência da imersão prolongada (por 24 horas) de fibras de polietileno em componentes comuns de adesivos, como acetona e etanol (solventes) e HEMA (hidroxietilmetacrilato). A microscopia eletrônica de varredura mostrou que a imersão em acetona dissolveu quase totalmente a fibra, enquanto a 
imersão em etanol causou fissuras superficiais; já o HEMA não afetou a fibra. Desta forma, adesivos contendo acetona ou etanol levariam a adesões mais fracas ou degradação das fibras ao longo do tempo; a análise da composição dos adesivos utilizados neste estudo em relação aos resultados obtidos confirmou tais afirmativas.

O efeito de um pino metálico e de três pinos estéticos na resistência à fratura e padrões de fratura de dentes endodonticamente tratados foram estudados por AKKAYAN; GÜLMEZ ${ }^{3}$, em 2002. Após remoção das coroas, 40 caninos superiores foram restaurados com pinos de titânio (Filpost), de dióxido de zircônia (Cosmopost), de fibras de quartzo (D.T. Light Post) ou de fibras de vidro (Para-Post Fiber White), classificados como grupos 1, 2, 3 e 4, respectivamente. Os pinos foram cimentados com cimento resinoso. A porção coronária do núcleo foi construída com resina composta e coroas metálicas foram cimentadas sobre os núcleos com ionômero de vidro. Os espécimes foram fixados em blocos de resina acrílica e submetidos à compressão em máquina de ensaios universal, em ângulo de $130^{\circ}$ ao longo eixo do dente e à velocidade de $1 \mathrm{~mm} / \mathrm{min}$. O grupo de pinos de fibras de quartzo exibiu resistência significantemente maior que os demais grupos (seguindose, em ordem decrescente, os grupos 4, 3 e 1). Pinos de zircônia e de fibras de vidro mostraram resistência similar. Fraturas passíveis de reparo foram observadas em dentes restaurados com pinos de fibra de quartzo (nenhuma fratura nos terços médio ou apical) e fbra de vidro, enquanto fraturas não restauráveis foram encontradas naqueles restaurados com pinos de zircônia e de titânio. Segundo os autores, uma das principais causas deste padrão de fratura poderia ser o alto módulo de elasticidade dos pinos de titânio e zircônia em relação à dentina, enquanto pinos de fibras de quartzo ou de fibras de vidro possuem módulos próximos ao da dentina.

HEYDECKE; PETERS ${ }^{49}$, em 2002, conduziram uma revisão da literatura para comparar o comportamento clínico e laboratorial de núcleos metálicos fundidos com o de pinos pré-fabricados (metálicos ou de fibras de carbono). Após seleção inicial de 1773 artigos, estes foram submetidos a critérios de inclusão. Para estudos laboratoriais, os critérios foram: dentes unirradiculares, restauração final com coroas totais e aplicação da carga em ângulo de 130 a 135; para estudos clínicos foram: período de acompanhamento de pelo menos três anos, dentes anteriores, 
restauração final com coroas totais (inclusive próteses parciais fixas), descrição dos sistemas testados e informações sobre sobrevivência ou sucesso do estudo. Permaneceram dez artigos laboratoriais e seis clínicos. A comparação da resistência à fratura nos estudos laboratoriais não revelou diferenças significantes entre núcleos fundidos e núcleos de preenchimento. Por falta de dados, uma análise global de sobrevivência não foi possível com estudos clínicos. A sobrevivência para núcleos metálicos fundidos em dois estudos variou de $87,2 \%$ a $88,1 \%$ e em um terceiro estudo alcançou 86,4\% após 72 meses. A meta-análise dos dados de estudos laboratoriais não encontrou diferenças no padrão de fratura entre as duas formas de tratamento: a maioria das fraturas ocorreu no terço médio ou apical da raiz. Somente com pinos de fibras de carbono a fratura geralmente ocorreu acima do suporte acrílico (fratura restaurável). Observaram que se os resultados dos tratamentos são comparáveis, restaurações diretas reduzirão tempo e custos para o paciente. Porém, estudos adicionais de acompanhamento de núcleos de preenchimento deveriam ser conduzidos, pois ainda são escassos.

HEYDECKE et al. ${ }^{50}$, em 2002, compararam a resistência à fratura de 64 incisivos centrais superiores tratados endodonticamente, divididos em quatro grupos iguais e restaurados com diferentes sistemas de núcleos. Após remoção da coroa, o grupo 1 foi restaurado com pinos de titânio (ER Komet) e porção coronária em resina composta; o grupo 2 com pinos de zircônia (Cerapost) e porção coronária em resina composta e o grupo 3 com pinos de zircônia e porção coronária de zircônia prensada (Empress-Cosmo). Dentes restaurados com núcleos metálicos fundidos em ouro serviram como controle (grupo 4). O término dos preparos foi um chanfrado incluindo $1-2 \mathrm{~mm}$ de férula em estrutura dentária. A cimentação foi com cimento resinoso. Coroas totais foram cimentadas com ionômero de vidro sobre os preparos e os dentes foram expostos a 1,2 milhões de ciclos (força de $30 \mathrm{~N}$ ) para simular cinco anos de mastigação. Termociclagem simultânea foi aplicada (entre $5^{\circ} \mathrm{C}$ e $55^{\circ} \mathrm{C}$ ). Após exposição dos dentes aos ciclos de carga, os seguintes padrões de sobrevivência foram registrados: 93,8\% (grupo 1 e 2), 100\% (grupo 3) e 87,5\% (grupo 4). Os espécimes sobreviventes à carga dinâmica foram submetidos à compressão em máquina de ensaios universal à velocidade de $1,5 \mathrm{~mm} / \mathrm{min}$ e em ângulo de $130^{\circ} \mathrm{com} \mathrm{o}$ longo eixo dentário. Não houve diferença significante na resistência à fratura entre os 
quatro grupos. Pinos metálicos causaram mais fraturas não restauráveis que pinos de zircônia. Os autores concluíram que se pode recomendar pinos de zircônia com porção coronária em cerâmica prensada como alternativa aos núcleos metálicos fundidos, bem como pinos de titânio ou zircônia com porção coronária em resina composta, quando houver preferência por procedimentos diretos.

OTTL et al. $^{89}$, em 2002, avaliaram resistência à fratura e tipo de fratura de sete sistemas de pinos (diâmetro e comprimento similares): um pino metálico contendo paládio (Perma-dor $[\mathrm{A}]$ ), três pinos metálicos sem paládio (Perma-dor twin [B], ER platinium-iridium [C], Endo-Core Pt-Ir [D]), dois cerâmicos (pino de zircônia Cerapost $[\mathrm{E}]$ e núcleos de preenchimento de óxido de alumínio obtido em sistema Celay [F]), pino de fibras de carbono (Composipost [G]) e pino metálico com porção coronária em cerâmica (Perma-dor e cerâmica SMH $[\mathrm{H}])$. Utilizourse ainda um grupo controle sem pinos (I). As porções coronárias dos sistemas A-D foram construídas em liga metálica e para os pinos E e G foram construídas em resina composta autopolimerizável. Confeccionaram-se raízes artificiais de resina composta com módulo de elasticidade equivalente ao da dentina para simular incisivos centrais superiores. Os pinos e as coroas totais metálicas foram cimentados com cimento resinoso. Após armazenamento dos espécimes em 100\% de umidade por 24 horas, estes receberam carga compressiva em ângulo de $135^{\circ}$ ao longo eixo do dente, à velocidade de $0,5 \mathrm{~mm} / \mathrm{min}$ até a fratura. A resistência mais alta foi obtida com pinos de fibras de carbono (31,8kgf), possivelmente graças ao módulo de elasticidade próximo ao da dentina. A resistência de pinos metálicos sem paládio $(24,7 \mathrm{kgf}-30,6 \mathrm{kgf})$ não diferiu significantemente daquela do pino que continha paládio $(27,1 \mathrm{kgf})$. Os valores dos pinos cerâmicos diferiram significantemente entre si (30,6kgf para óxido de alumínio e 19,7kgf para zircônia). Para o pino metálico com porção coronária em cerâmica a resistência foi de $21,2 \mathrm{kgf}$. O grupo controle exibiu numericamente a menor resistência (23,3kgf), porém sem diferença significante dos grupos com pinos. Qualitativamente, as posições das linhas de fraturas foram similares com todos os sistemas de pinos; geralmente, uma linha de fratura oblíqua iniciava-se no terço médio da face palatina radicular, estendendo-se usualmente até o terço apical na superfície oposta da raiz. 


\section{PROPOSIÇÃO}

Diante da necessidade de desenvolverem-se técnicas capazes de restaurar adequadamente raízes debilitadas pelo excessivo alargamento dos condutos radiculares, evitando desta forma sua exodontia prematura, a presente pesquisa buscou:

3.1. Avaliar a resistência à fratura de dentes tratados endodonticamente reconstruídos com pinos de fibras de polietileno e com pinos dentários, cimentados em raízes com diferentes graus de perda de estrutura dentária;

3.2. Avaliar o tipo de fratura gerada nestes dentes, quando submetidos à carga compressiva de $135^{\circ}$ em relação ao longo eixo da raiz. 
4 MATERIAL E MÉTODOS 


\section{MATERIAL E MÉTODOS}

\subsection{Material}

Para a realização desta pesquisa utilizou-se o material descrito na

Figura 4.1.

\begin{tabular}{|c|c|c|}
\hline MATERIAL & NOME COMERCIAL & FABRICANTE \\
\hline \multicolumn{3}{|l|}{$\begin{array}{l}\text { Dentes caninos humanos } \\
\text { superiores e inferiores }\end{array}$} \\
\hline Fibras de polietileno & Ribbond & Ribbond Inc., Seattle - USA \\
\hline $\begin{array}{l}\text { Limas de aço inoxidável } n^{\circ} 15 \\
\text { a } 35\end{array}$ & K-flex & $\begin{array}{l}\text { Sybrion / Kerr, Basel - } \\
\text { Swiss }\end{array}$ \\
\hline Pontas de papel absorvente & Tanari & $\begin{array}{l}\text { Tamariman Industrial Ltda., } \\
\text { Macaçaruru - AM }\end{array}$ \\
\hline $\begin{array}{l}\text { Cones de guta-percha } \\
\text { calibrados }\end{array}$ & Tanari & $\begin{array}{l}\text { Tamariman Industrial Ltda., } \\
\text { Macaçaruru - AM }\end{array}$ \\
\hline Hipoclorito de sódio $1 \%$ & Líquido de Milton & $\begin{array}{l}\text { Biodinâmica Química e } \\
\text { Farmacêutica Ltda., Ibiporã } \\
\text { - PA }\end{array}$ \\
\hline $\begin{array}{l}\text { Ácido } \\
\text { etilenodiaminotetracético }\end{array}$ & EDTA trissódico $24 \%$ & $\begin{array}{l}\text { Biodinâmica Química e } \\
\text { Farmacêutica Ltda., Ibiporã } \\
\text { - PA }\end{array}$ \\
\hline Cimento endodôntico & Pulp Fill & $\begin{array}{l}\text { Biodinâmica Química e } \\
\text { Farmacêutica Ltda., Ibiporã } \\
\text { - PA }\end{array}$ \\
\hline $\begin{array}{l}\text { Resina acrílica } \\
\text { autopolimerizável }\end{array}$ & Clássico & $\begin{array}{l}\text { Clássico Artigos } \\
\text { Odontológicos S/A - Brasil }\end{array}$ \\
\hline $\begin{array}{l}\text { Resina acrílica } \\
\text { autopolimerizável }\end{array}$ & Duralay & $\begin{array}{l}\text { Reliance Dental } \\
\text { Manufactaring Co., Worth, } \\
\text { Illinois - USA }\end{array}$ \\
\hline $\begin{array}{l}\text { Pontas diamantadas } \mathrm{n}^{\circ} \\
\text { 1016HL, 3017HL, 3018, 3195, } \\
3216,4138\end{array}$ & & $\begin{array}{l}\text { KG Sorensen Ind. e Com. } \\
\text { Ltda., São Paulo - SP }\end{array}$ \\
\hline Brocas Largo $n^{\circ} 1$ a 4 & & $\begin{array}{l}\text { Dentsply / Maillefer - } \\
\text { Swiss }\end{array}$ \\
\hline Gesso especial & Durone & $\begin{array}{l}\text { Dentsply Ind. e Com., Rio } \\
\text { de Janeiro - RJ }\end{array}$ \\
\hline Evidenciador de contatos & Arti-Spot 2 & $\begin{array}{l}\text { Bausch Articulating } \\
\text { Papers, Inc., Nashua, NH - } \\
\text { USA }\end{array}$ \\
\hline Guta-percha em bastões & Guta-percha Odhacam & $\begin{array}{l}\text { Herpo Produtos Dentários } \\
\text { Ltda, Rio de Janeiro - RJ }\end{array}$ \\
\hline
\end{tabular}

(Continua) 
(Continuação da Figura 4.1)

\begin{tabular}{|c|c|c|}
\hline Espessímetro & Espessímetro Otto & $\begin{array}{l}\text { Arminger e Cia. Ltda,São } \\
\text { Leopoldo - RS }\end{array}$ \\
\hline Sistema adesivo & $\begin{array}{l}\text { Scotchbond Multi-Uso } \\
\text { Plus }\end{array}$ & $\begin{array}{l}\text { 3M do Brasil Ltda. } \\
\text { Produtos Dentários, } \\
\text { Sumaré - SP }\end{array}$ \\
\hline Cunha reflexiva & Cunhas reflexivas TDV & $\begin{array}{l}\text { TDV Dental, Pomerode - } \\
\text { SC }\end{array}$ \\
\hline $\begin{array}{l}\text { Ácido fosfórico } 37 \% \text { em } \\
\text { gel }\end{array}$ & Ácido fosfórico Dentsply & $\begin{array}{l}\text { Dentsply Ind. e Com., Rio } \\
\text { de Janeiro - RJ }\end{array}$ \\
\hline Cimento resinoso dual & Enforce com Flúor & $\begin{array}{l}\text { Dentsply Ind. e Com., } \\
\text { Petrópolis, Rio de Janeiro- } \\
\text { RJ }\end{array}$ \\
\hline $\begin{array}{l}\text { Resina composta } \\
\text { autopolimerizável }\end{array}$ & Ti-Core & $\begin{array}{l}\text { EDS (Essential Dental } \\
\text { Systems), S. Hackensack, } \\
\text { NJ - USA }\end{array}$ \\
\hline $\begin{array}{l}\text { Seringa para inserção de } \\
\text { materiais plásticos }\end{array}$ & Centrix & Centrix Inc., Milford - USA \\
\hline Silicona de condensação & $\begin{array}{l}\text { Zetalabor Extra-Hard / } \\
\text { Ruthinium Activator }\end{array}$ & $\begin{array}{l}\text { Zhermack S. A., Badia } \\
\text { Polesine, Rovigo - Itália }\end{array}$ \\
\hline Sistema adesivo & $\begin{array}{l}\text { Prime e Bond } 2.1 \text { / Self } \\
\text { Cure Activator }\end{array}$ & $\begin{array}{l}\text { Dentsply Ind. e Com., } \\
\text { Petrópolis, Rio de Janeiro } \\
\text { - RJ }\end{array}$ \\
\hline Delineador & Delineador Bio-Art & $\begin{array}{l}\text { Bio-Art Equipamentos } \\
\text { Odontológicos Ltda., São } \\
\text { Carlos - SP }\end{array}$ \\
\hline Ponta aplicadora & Microbrush & $\begin{array}{l}\text { Microbrush Corporation , } \\
\text { Grafton - USA }\end{array}$ \\
\hline $\begin{array}{l}\text { Aparelho } \\
\text { fotopolimerizador }\end{array}$ & $\begin{array}{l}\text { Fotopolimerizador } \\
\text { Demetron Model } 100\end{array}$ & $\begin{array}{l}\text { Demetron Research Corp., } \\
\text { Danruby, CT - USA }\end{array}$ \\
\hline Plastificador a vácuo & Plastivac & $\begin{array}{l}\text { Bio-Art Equipamentos } \\
\text { Odontológicos Ltda., São } \\
\text { Carlos - SP }\end{array}$ \\
\hline Lupa & Lupa Bio-Art 4x & $\begin{array}{l}\text { Bio-Art Equipamentos } \\
\text { Odontológicos Ltda., São } \\
\text { Carlos - SP }\end{array}$ \\
\hline $\begin{array}{l}\text { Máquina de ensaios } \\
\text { universal }\end{array}$ & Modelo K-2000MP & $\begin{array}{l}\text { Dinamômetros Kratos } \\
\text { Ltda., São Paulo - SP }\end{array}$ \\
\hline
\end{tabular}

FIGURA 4.1 - Material utilizado na pesquisa

\subsection{Métodos}

Ensaios preliminares (testes pilotos) foram executados com a finalidade de aperfeiçoar o experimento e verificar a viabilidade da metodologia idealizada. 


\subsubsection{Seleção dos dentes}

Para realização desse estudo, utilizourse uma amostra de 60 caninos superiores com dimensões similares, livres de qualquer tipo de lesão cervical (cárie, erosão ou abrasão), defeitos nas raízes ou tratamento endodôntico prévio. Estes dentes, oriundos do Banco de Dentes da Faculdade de Odontologia da UFSM, foram esterelizados em autoclave e armazenados em condições úmidas (solução isotônica de cloreto de sódio a $0,9 \%$ com cristais de timol a $0,1 \%$ ), antes e durante todo o curso do experimento, prevenindo sua desidratação. $\mathrm{O}$ manuseio dos dentes foi feito sempre com gaze úmida.

Os dentes foram aleatoriamente distribuídos em quatro grupos experimentais com 15 corpos de prova cada:

Grupo 1: dentes com preparo convencional dos condutos e restaurados com pinos de fibras de polietileno Ribbond;

Grupo 2: dentes com preparo convencional dos condutos e restaurados com pinos dentários;

Grupo 3: dentes com condutos medianamente alargados e restaurados com pinos dentários;

Grupo 4: dentes com condutos amplamente alargados e restaurados com pinos dentários.

Os quatro grupos experimentais encontram-se representados na Figura 4.2, e os desgastes executados em cada um destes grupos estão representados na Figura 4.3.

Uma vista oclusal do preparo executado em cada um dos quatro grupos experimentais pode ser observada na Figura 4.4. 

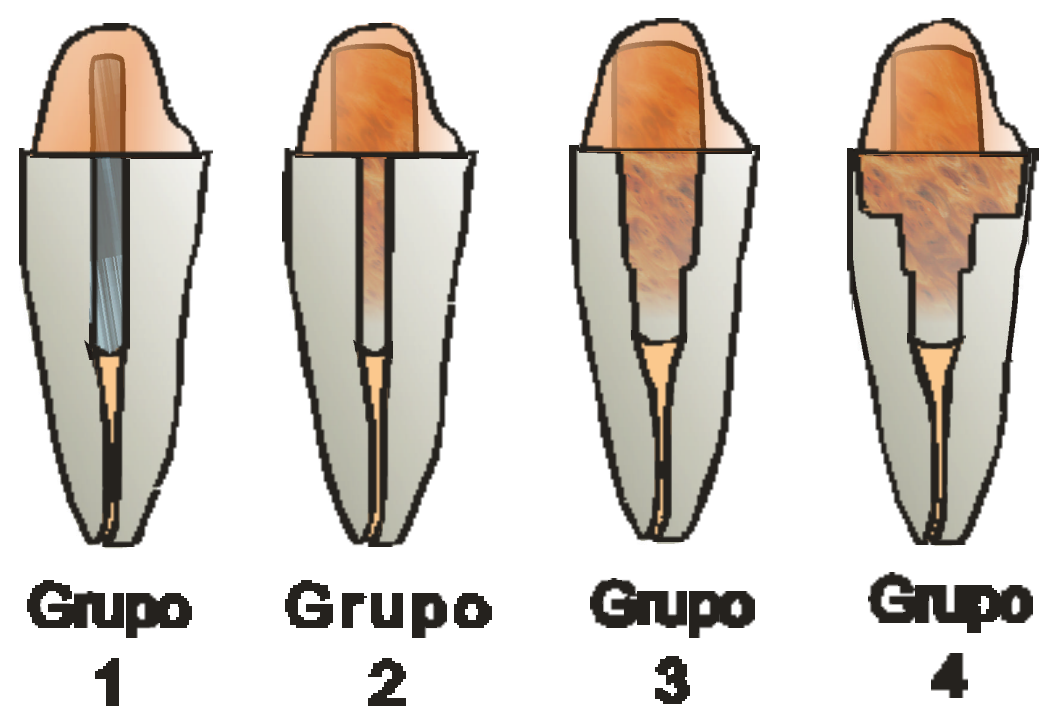

FIGURA 4.2 - Representação esquemática dos quatro grupos experimentais

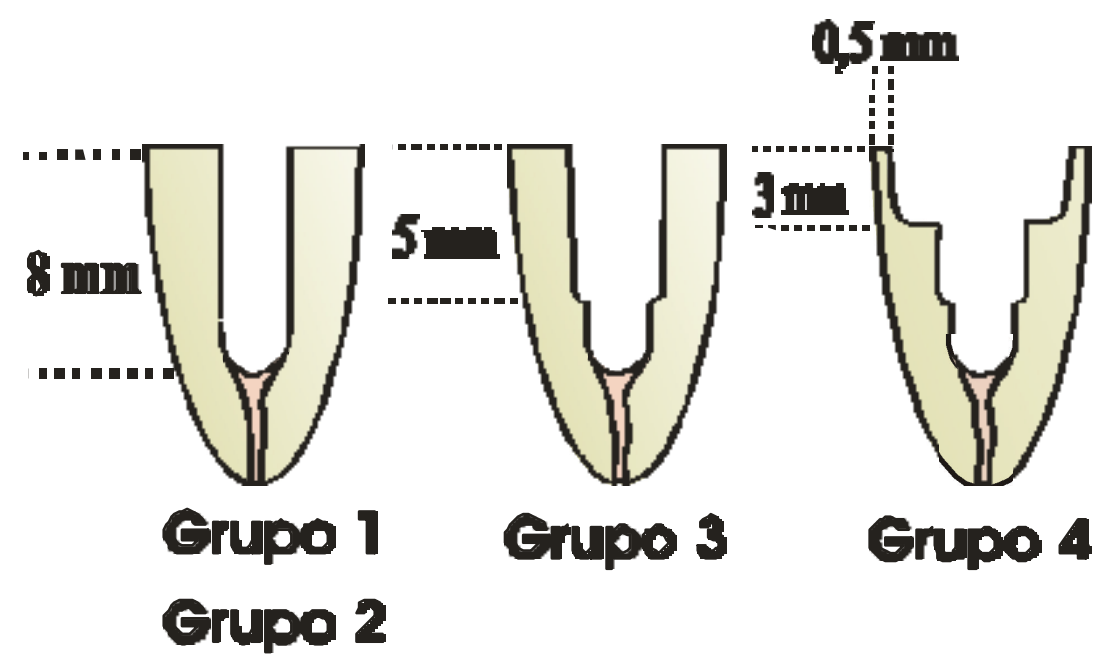

FIGURA 4.3 - Representação esquemática dos preparos intra-radiculares executados em cada grupo experimental 


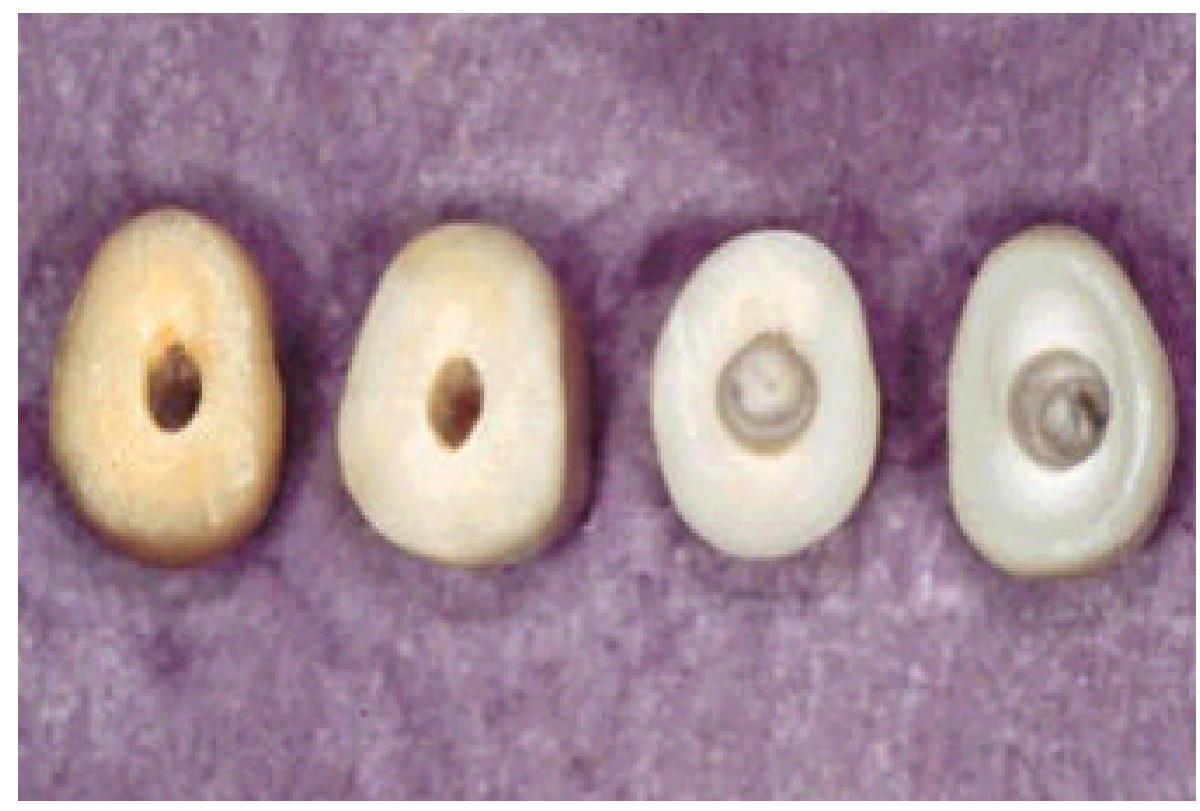

FIGURA 4.4 - Vista incisal do preparo dos condutos nos quatro grupos experimentais

\subsubsection{Preparo dos corpos de prova}

\subsubsection{Procedimentos prévios}

\section{a. Tratamento endododôntico}

As aberturas das câmaras coronárias para terapia endodôntica foram executadas da forma convencional. Para a instrumentação endodôntica, utilizaram-se limas de aço inoxidável e abundante irrigação com hipoclorito de sódio a $1 \%$ (solução de Milton). Para a secagem dos condutos, utilizaram-se pontas de papel absorvente Tanari. Os condutos foram preparados no limite de $1 \mathrm{~mm}$ aquém do ápice radicular, até a lima número 35 da $1^{\mathrm{a}}$ série da International Standartization Organization (ISO) e obturados com cones de guta-percha de calibre correspondente e cimento endodôntico.

\section{b. Secção da porção coronária}

As coroas dos elementos dentários foram seccionadas com discos diamantados de dupla face, sob refrigeração com spray ar-água da seringa tríplice, ao nível da junção cemento-esmalte, de forma perpendicular ao longo eixo do dente e em plano reto. $\mathrm{O}$ remanescente radicular foi regularizado com pontas diamantadas 3216 e 4138 em baixa-rotação. Os remanescentes, padronizados a um comprimento 
médio de $15 \mathrm{~mm}$, foram mantidos como parte dos grupos quando apresentavam diâmetro das porções mais coronárias das raízes de 5 a 5,5mm no sentido mésiodistal e de 7 a 7,5mm no sentido vestíbulo-palatino. Para mensuração das raízes utilizou-se um espessímetro capaz de fornecer precisão de até $0,1 \mathrm{~mm}$ e um compasso.

\section{c. Fixação das raízes em cilindros plásticos}

As raízes foram fixadas em cilindros ocos de PVC com $22 \mathrm{~mm}$ de diâmetro e $30 \mathrm{~mm}$ de altura, utilizando-se resina acrílica autopolimerizável e mantendo-se uma altura de $3 \mathrm{~mm}$ de raiz exposta. Para que todos os dentes permanecessem posicionados no interior dos cilindros em posição central e perpendicular à base dos mesmos, utilizou-se um delineador. Após polimerização da resina, todos os cilindros foram numerados e mantidos em condições úmidas no interior de recipientes para armazenamento de filmes fotográficos.

\subsubsection{Preparo dos corpos de prova do grupo 1}

Neste grupo, foram confeccionados 15 núcleos utilizando-se fibras de polietileno Ribbond (fitas com $2 \mathrm{~mm}$ de largura e $0,33 \mathrm{~mm}$ de espessura).

A desobturação parcial do conduto radicular foi executada até a profundidade de $8 \mathrm{~mm}$, controlada pelo uso de cursores de borracha. Inicialmente utilizaram-se instrumentos aquecidos (pontas Rhein) para a desobturação, seguidos por brocas Largo com diâmetros crescentes, até a de número 4, que possui 1,1mm de diâmetro, no contra-ângulo em baixa rotação (Figura 4.3).

Foram cortados dois pedaços de fita com $35 \mathrm{~mm}$ de comprimento cada, utilizando-se a tesoura serrilhada especial fornecida pelo fabricante; o material era manipulado somente com pinças de algodão, com a finalidade de evitar seu contato com os dedos desprotegidos ou mesmo com luvas de látex, o que resultaria na contaminação de sua superfície reativa.

Irrigaram-se os condutos com EDTA e hipoclorito de sódio a $1 \%$ por cinco minutos, alternadamente, seguindo-se abundante lavagem com água por um minuto, visando-se a eliminação da lama dentinária e resíduos presentes nos condutos. Os condutos foram secos com cones de papel absorvente. O condicionamento ácido foi executado com gel de ácido fosfórico a 37\% por 60 
segundos, seguido por lavagem com água em abundância pelo dobro do tempo, secagem inicial com suaves jatos de ar aplicados a distância de 5 a $6 \mathrm{~cm}$ por três segundos e secagem final com cones de papel absorvente.

Utilizourse o sistema adesivo Scotchbond Multi-Uso Plus, tanto no conduto radicular quanto na porção mais coronária da raiz. Inicialmente aplicou-se o primer do sistema por dez segundos com ponta aplicadora Microbrush, secando-se com suaves jatos de ar por três segundos. A seguir aplicou-se o adesivo do mesmo sistema também com ponta aplicadora Microbrush, até obtenção de uma superfície bem saturada e brilhante. O excesso de adesivo foi removido com suaves jatos de ar por três segundos a uma distância de 5 a $6 \mathrm{~cm}$, bem como com cones de papel absorvente no conduto radicular e polimerizado por 20 segundos. Para complementar a polimerização inicial executou-se uma segunda polimerização por mais 20 segundos com cunha reflexiva no interior do conduto, colocando-se a ponta da lâmpada fotopolimerizadora no extremo cervical dessa cunha. A intensidade de luz do aparelho fotopolimerizador $\left(400 \mathrm{Mw} / \mathrm{cm}^{2}\right)$ era conferida em radiômetro antes de cada utilização.

As fitas fram cuidadosamente impregnadas somente com o adesivo do Scotchbond Multi-Uso Plus, cujo excesso foi removido com papel absorvente. O adesivo da fita não deve ser polimerizado.

Para a cimentação, foi utilizado o cimento resinoso dual Enforce com Flúor. Manipulava-se quantidades iguais das pastas base e catalisadora do cimento até obtenção de mistura de cor uniforme. Enquanto se manipulava o cimento, as fitas de Ribbond com adesivo eram mantidas protegidas da luz. Uma fina camada de cimento foi aplicada sobre as fitas com pincel descartável pequeno e nas paredes do conduto radicular c/ pontas Rhein.

As duas fitas foram cruzadas transversalmente (em orientação perpendicular entre si) sobre a embocadura do conduto radicular, e então condensadas em seu interior utilizando-se condensadores endodônticos $n^{\circ} 2$ e 3 . As quatro pontas de Ribbond que emergiram do conduto foram presas com uma pinça hemostática e torcidas, formando um pino espesso e rígido. $\mathrm{O}$ conjunto foi fotopolimerizado (40 segundos em cada face), obtendo-se um suporte para a porção coronária do núcleo com $4 \mathrm{~mm}$ de altura acima do nível cervical do remanescente 
radicular. Aguardavam-se seis minutos para polimerização total do cimento. A altura do pino foi avaliada com um compasso e eventuais excessos (mais de 4mm) eliminados. Neste caso, antes da confecção da porção coronária, a mesma técnica adesiva acima descrita foi repetida. Na Figura 4.5, observa-se a confecção de um núcleo à base de fibras de polietileno.
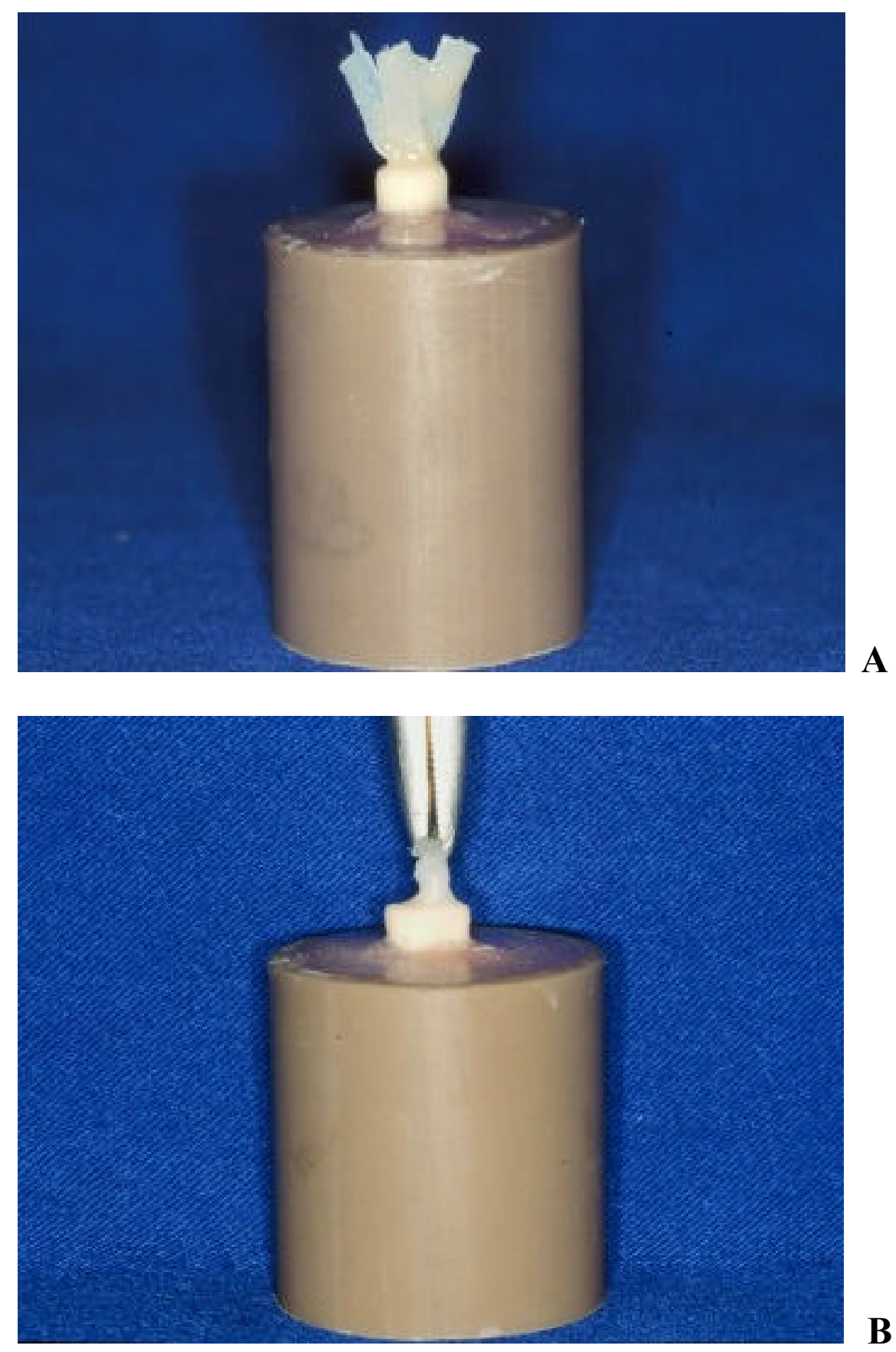

FIGURA 4.5 - Confecção de núcleo à base de fibras de polietileno

A) Fitas de Ribbond emergindo do conduto

B) Utilização de pinça hemostática para conformação do pino de fibras de polietileno 


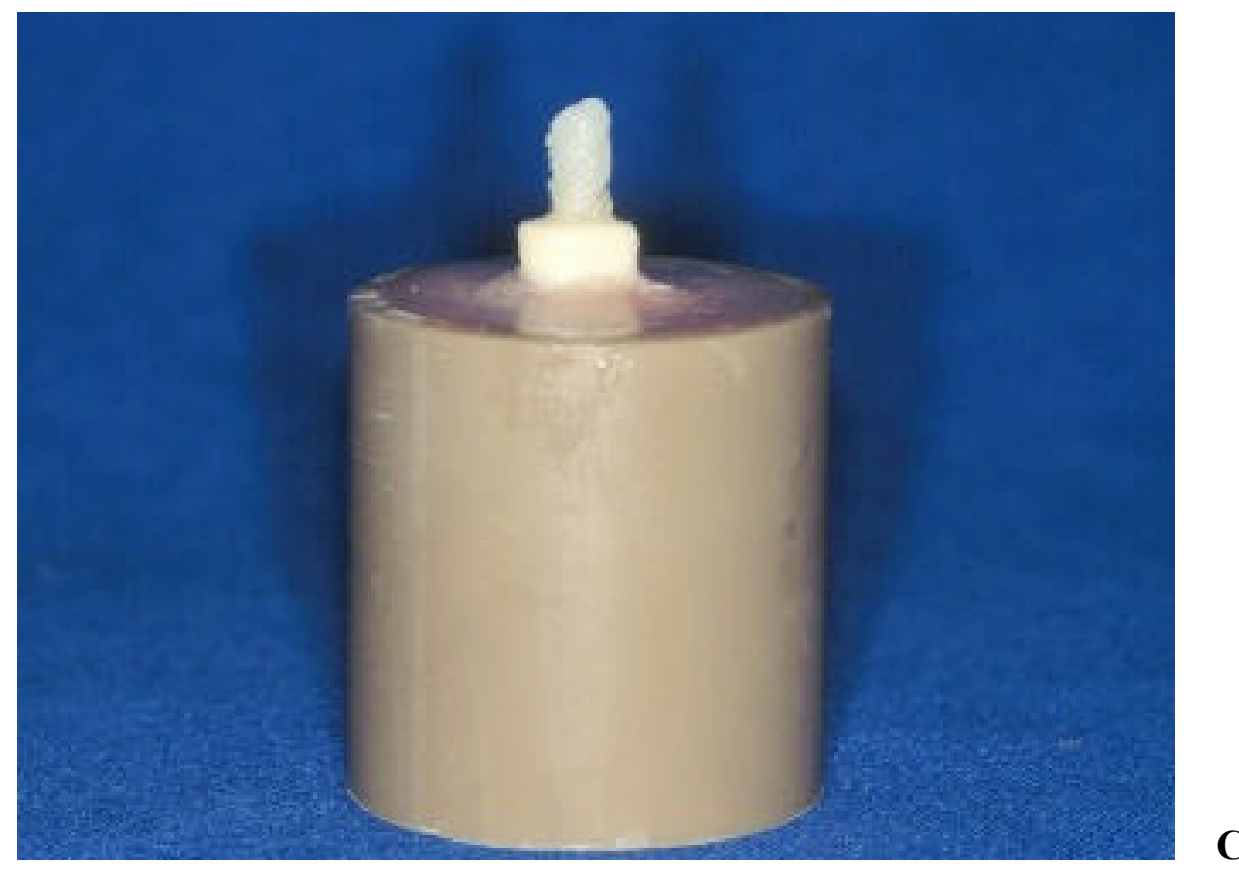

FIGURA 4.5 - Confecção de núcleo à base de fibras de polietileno

C) Pino de fibras de polietileno após polimerização do cimento resinoso

Para confecção da porção coronária do núcleo (com $5 \mathrm{~mm}$ de altura), utilizou-se a resina composta de polimerização química Ti-Core, especialmente idealizada para construção de núcleos de preenchimento (reforçada com titânio).

Para padronizar forma e dimensão da porção coronária dos núcleos obtiveram-se matrizes fabricadas em laboratório. Inicialmente confeccionou-se um padrão de um núcleo em resina acrílica quimicamente ativada Duralay sobre um dos dentes preparados. Este padrão simulava a forma anatômica de um preparo para coroa total de um canino superior, com $5 \mathrm{~mm}$ de altura e ombro de aproximadamente $1 \mathrm{~mm}$ em todo o diâmetro do término cervical. Este núcleo teve sua porção coronária moldada com silicona de condensação Zetalabor, obtendo-se (pelo vazamento dos moldes) cinco troquéis em gesso especial Durone, que foram fixados em uma base de gesso-pedra e levados ao plastificador a vácuo para serem reproduzidos na forma de matrizes de polipropileno para as porções coronárias.

Injetou-se com auxílio da seringa Centrix (para evitar formação de bolhas de ar) a resina para confecção da porção coronária do núcleo no interior da matriz, que foi posicionada sobre o pino. Removeram-se os excessos de Ti-Core 
com espátula para inserção de resina composta e manteve-se a matriz imóvel durante seis minutos, tempo necessário para o material sofrer autopolimerização.

Quando presentes, foram eliminados os excessos da porção coronária dos núcleos de preenchimento, utilizando-se pontas diamantadas 3216 e 4138 em baixa rotação no contra-ângulo. Após o acabamento dos preparos, os núcleos representavam a forma de caninos preparados para receber coroa total (Figura 4.6).

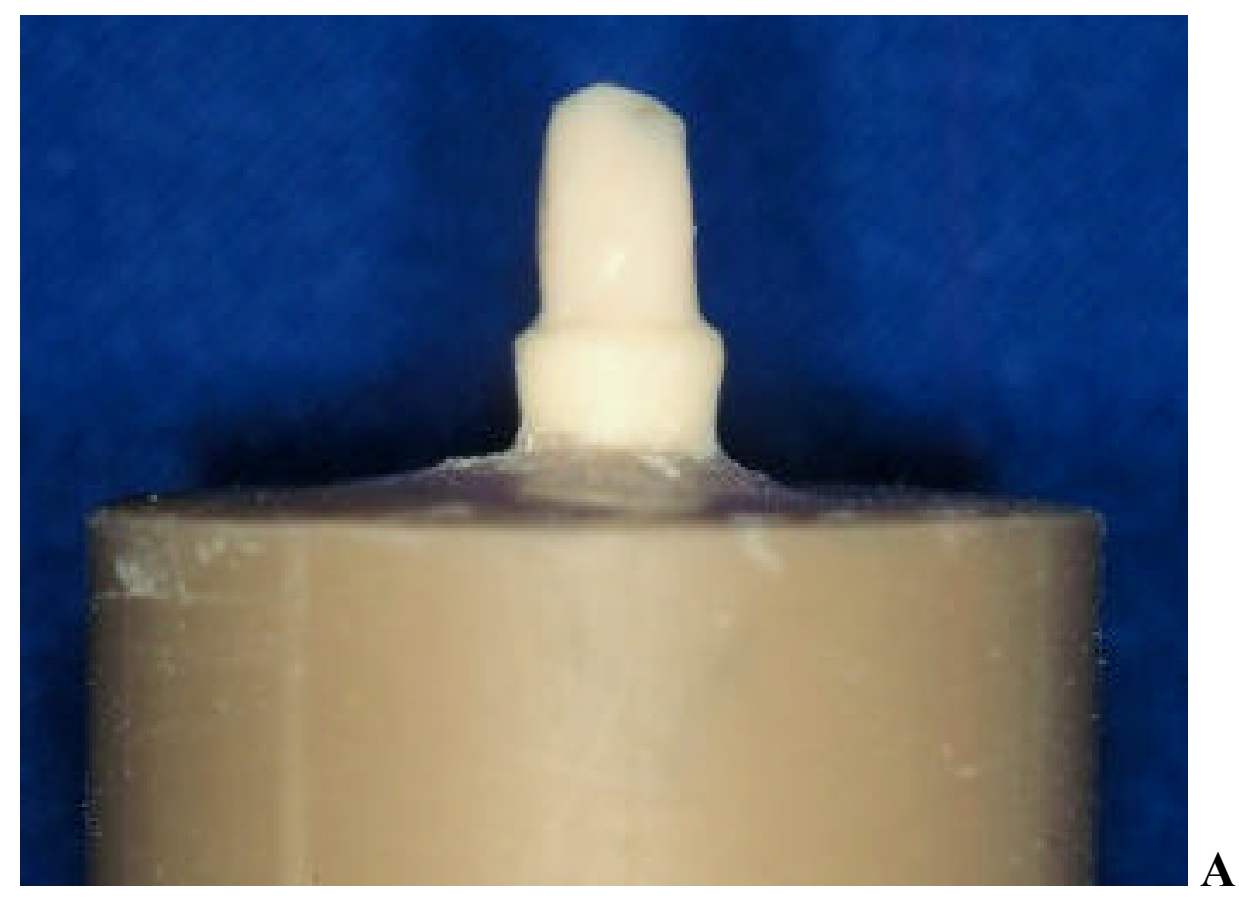

FIGURA 4.6 - Núcleo à base de fibras de polietileno

A) Vista frontal 


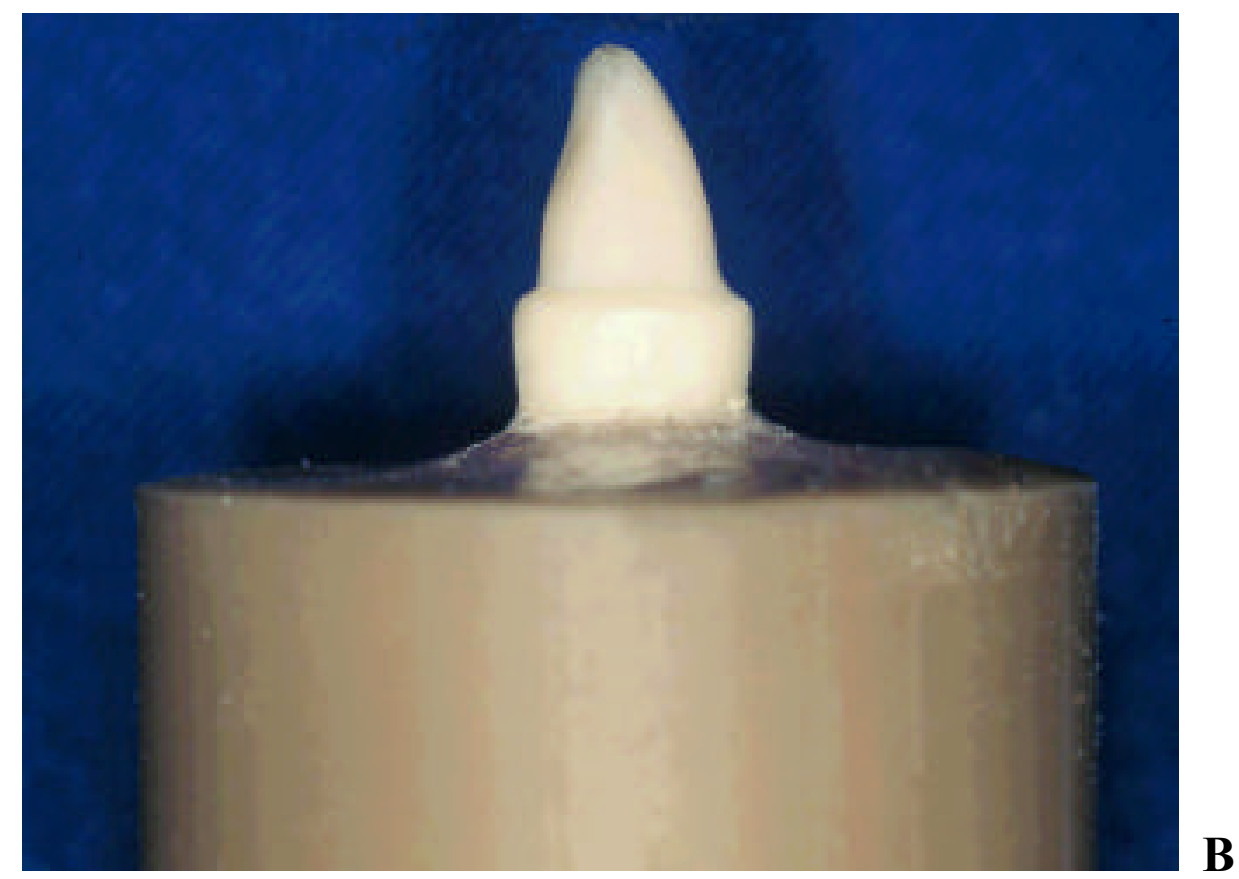

FIGURA 4.6 - Núcleo à base de fibras de polietileno

B) Vista lateral

\subsubsection{Preparo dos corpos de prova do grupo 2}

O grupo 2 consistiu de 15 caninos superiores tratados endodonticamente, com preparo convencional dos condutos e restaurados com pinos dentários, os quais foram confeccionados a partir de caninos inferiores hígidos e hidratados.

Os condutos radiculares dos dentes nos quais foram cimentados os pinos dentários foram preparados de forma idêntica à anteriormente descrita para o grupo 1 (Figura 4.3).

Para confecção dos pinos dentários, seccionaram-se caninos no sentido axial através de um micrótomo, obtendo-se fatias de aproximadamente $20 \mathrm{~mm}$ de comprimento por $4 \mathrm{~mm}$ de espessura vestíbulo-lingual e mésio-distal. Nesse corte, manteve-se uma porção com cerca de $5 \mathrm{~mm}$ de altura da coroa, sendo o restante obtido a partir da raiz. Posteriormente, essas fatias foram ajustadas com pontas diamantadas sob refrigeração com spray ar-água, de modo a se obter um pino cuja porção coronária possuía aproximadamente $3 \mathrm{~mm}$ de diâme tro e comprimento total de $12 \mathrm{~mm}$ ( $8 \mathrm{~mm}$ no interior do conduto radicular e $4 \mathrm{~mm}$ de altura coronária). 
A adaptação do pino dentário no interior do conduto radicular realizou-se por meio de tentativas, utilizando-se o evidenciador de contatos Arti-Spot 2 aplicado sobre a porção radicular do pino, que era então inserido no canal. Os pontos de contato prematuros demarcados foram gradativamente eliminados com pontas diamantadas 3195, 3216 e 4138 em baixa rotação e lupa de quatro aumentos, até que se obtivesse adaptação adequada do pino no interior do conduto radicular. $\mathrm{Na}$ Figura 4.7 observa-se um pino dentário do grupo 2.

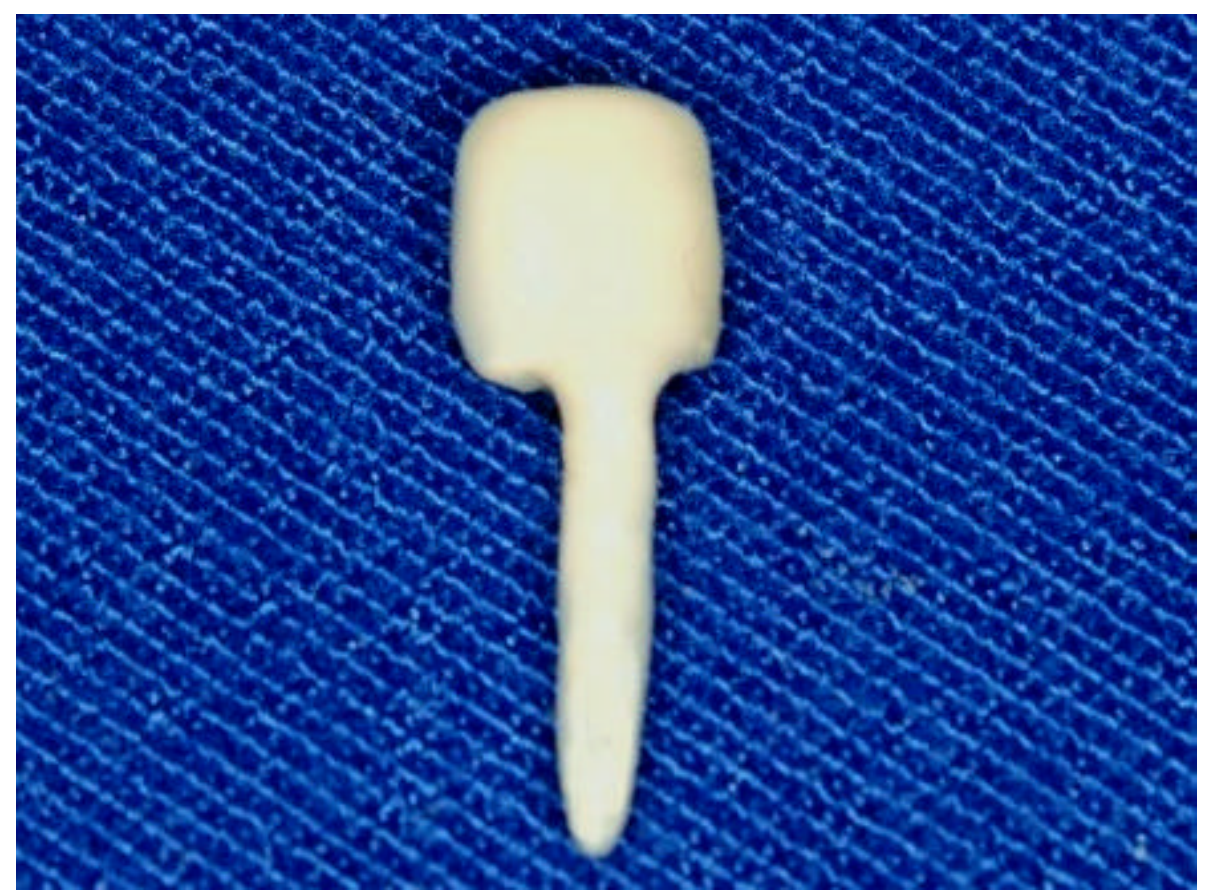

FIGURA 4.7 - Pino dentário do grupo 2

O tratamento do conduto e da porção coronária da raiz, no que se refere ao condicionamento ácido e à utilização do sistema adesivo, foi idêntico ao anteriormente descrito para o grupo 1 .

O pino dentário foi também submetido a condicionamento ácido e aplicação do sistema adesivo, sendo previamente fixado a um bastão de guta-percha pela porção coronária para facilitar sua manipulação.

Os pinos dentários foram cimentados com cimento resinoso dual Enforce com Flúor, aplicando-se uma fina camada sobre a superfície radicular do pino com pincel descartável pequeno, bem como mo interior do conduto radicular 
com pontas Rhein. Assentou-se o pino lentamente no conduto com pressão digital, removendo-se o excesso de cimento com pincel seco e levando-se o conjunto à prensa estática (Figura 4.8), onde foi submetido a uma carga de $2 \mathrm{~kg}$ por seis minutos.

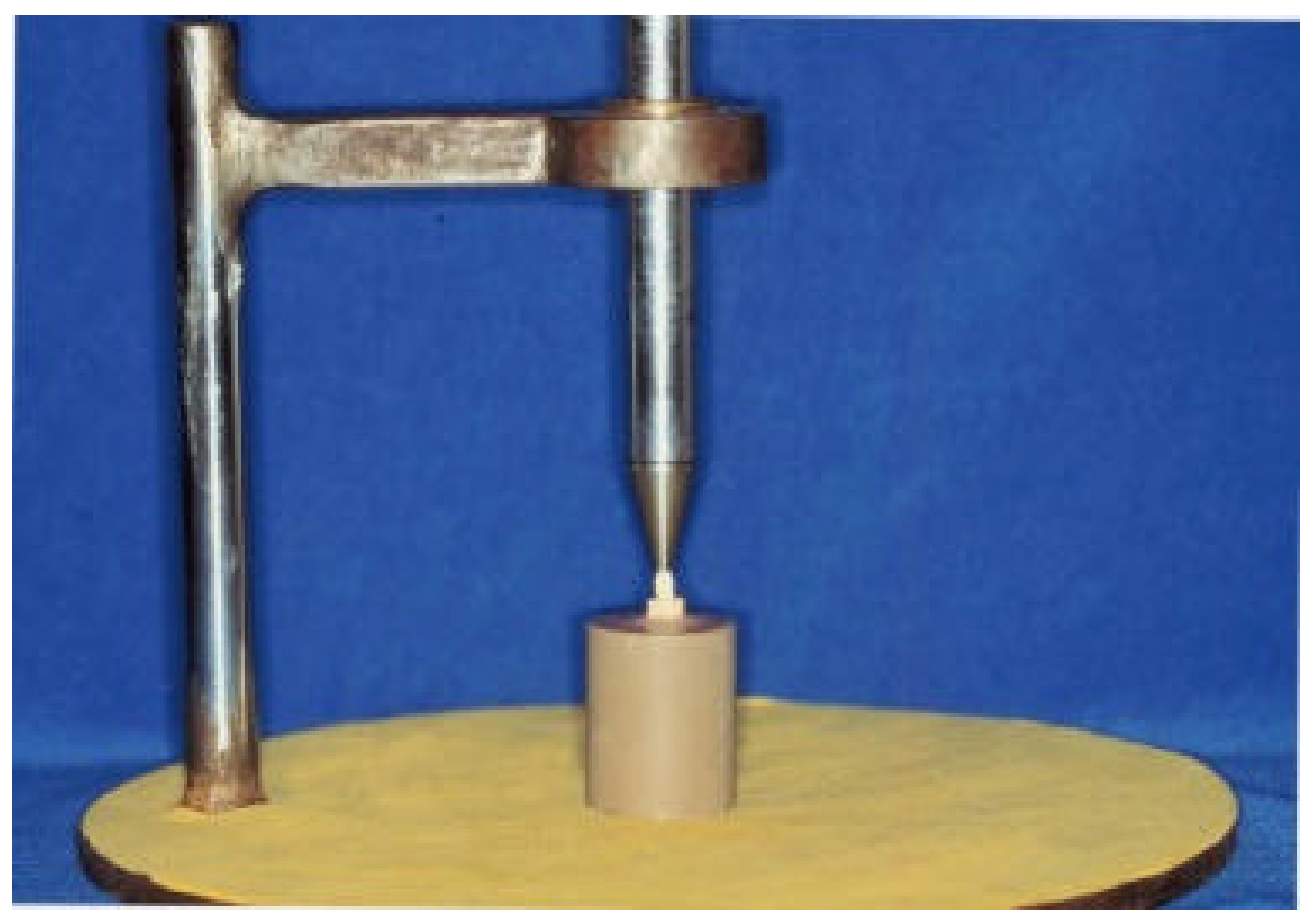

FIGURA 4.8 - Pino dentário sendo submetido à aplicação de carga na prensa estática

Após repetição da técnica adesiva sobre o pino, a porção coronária do núcleo foi confeccionada com Ti-Core da mesma forma descrita para o grupo 1 .

\subsubsection{Preparo dos corpos de prova do grupo 3}

O grupo 3 consistiu de 15 caninos superiores tratados endodonticamente e restaurados com pinos dentários escalonados, confeccionados a partir de caninos inferiores humanos hígidos e hidratados.

O preparo do conduto radicular destes dentes foi executado de forma escalonada (com dois degraus), constituindo o grupo denominado medianamente alargado. Utilizourse a ponta diamantada $1016 \mathrm{HL}$, que possui diâmetro de $1,8 \mathrm{~mm}$, penetrando $8 \mathrm{~mm}$ no conduto (atingindo-se assim a profundidade de preparo do 
conduto). Para confecção do degrau mais cervical, com profundidade de $5 \mathrm{~mm}$, utilizoutse a ponta diamantada $3017 \mathrm{HL}$, que possui diâmetro de $2,5 \mathrm{~mm}$. O desgaste interno das raízes do grupo 3 está representado na Figura 4.3. Empregou-se uma sonda periodontal para controlar a profundidade de penetração de cada ponta, bem como uma marca na haste das pontas diamantadas utilizadas.

Também para auxiliar na confecção dos pinos dentários escalonados em dois degraus, confeccionou-se um padrão de resina acrílica Duralay, conforme descrito por BONILLA ${ }^{12}$, em 2001. Este padrão servia de guia para o desgaste inicial do pino dentário, pois era colocado sobre a superfície do dente a ser desgastado, sendo seu contorno reproduzido com grafite (Figura 4.9).

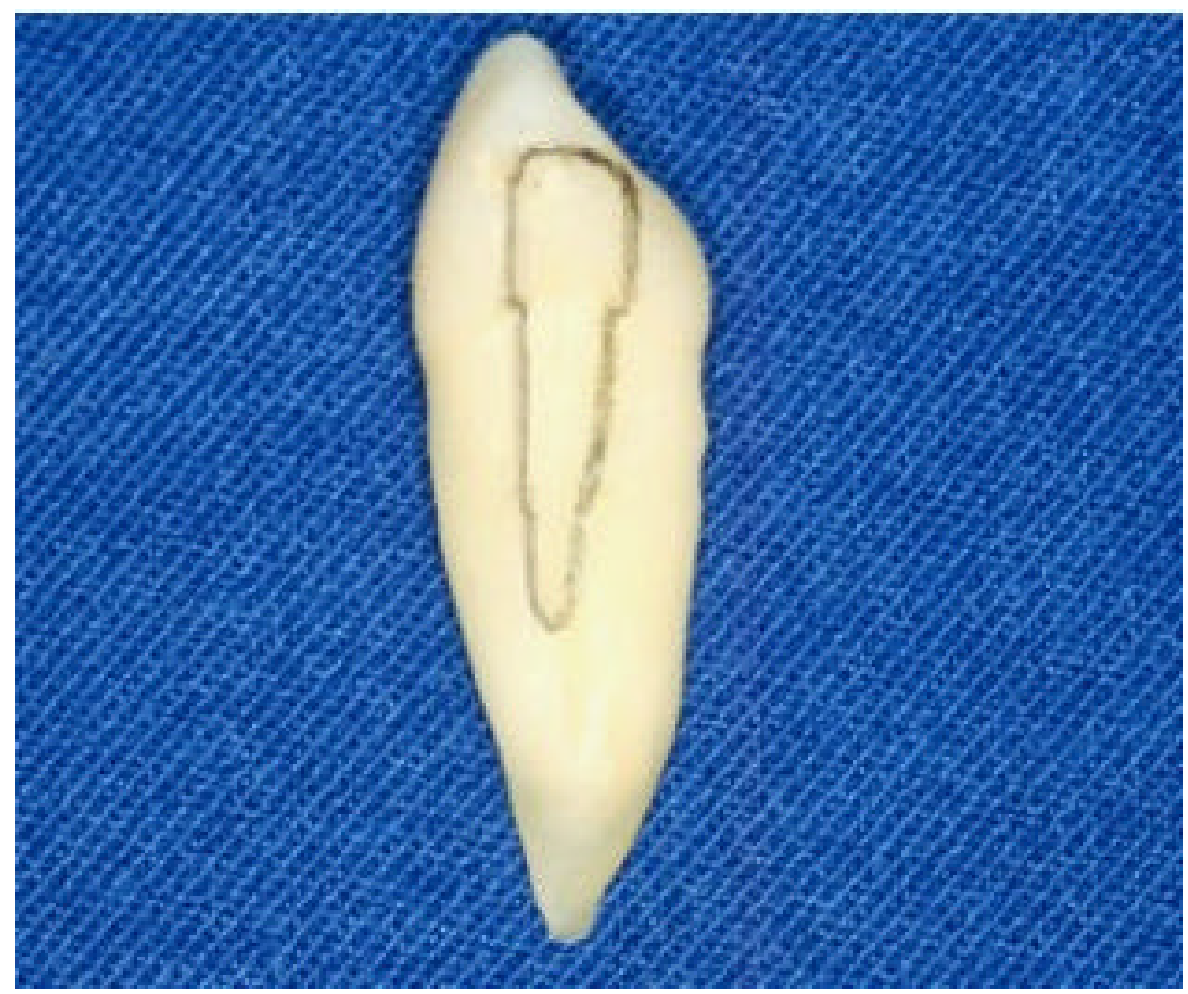

FIGURA 4.9 - Desenho do pino dentário após a utilização do padrão de resina acrílica 
Para auxiliar a conferir o desgaste, o padrão de Duralay foi copiado com a silicona de condensação Zetalabor, sendo confeccionadas duas matrizes para cada dente, uma com corte no sentido vestíbulo-lingual e outra com corte no sentido mésio-distal (Figura 4.10). Durante o desgaste do pino, testou-se sua adaptação nessas matrizes.

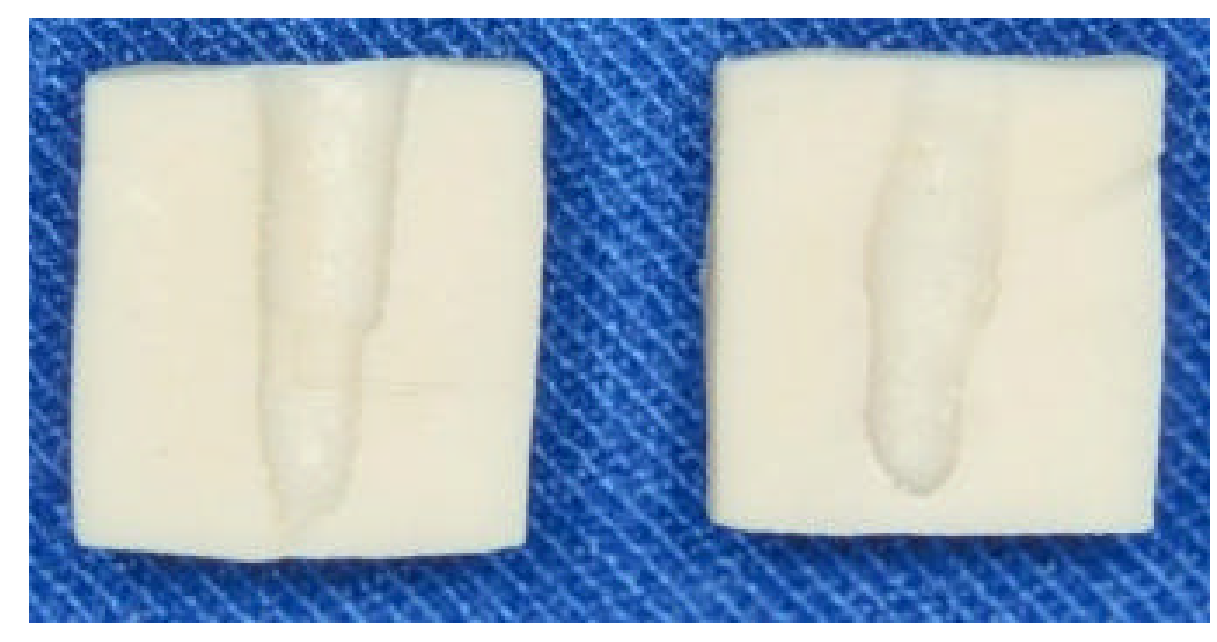

FIGURA 4.10 - Matrizes de silicona de condensação confeccionadas a partir do padrão de resina acrílica, para auxiliar a conferir o desgaste

Utilizourse ainda o evidenciador de contatos Arti-Spot 2 (Figura 4.11 a 4.14), da mesma forma já descrita para o grupo 2 . 


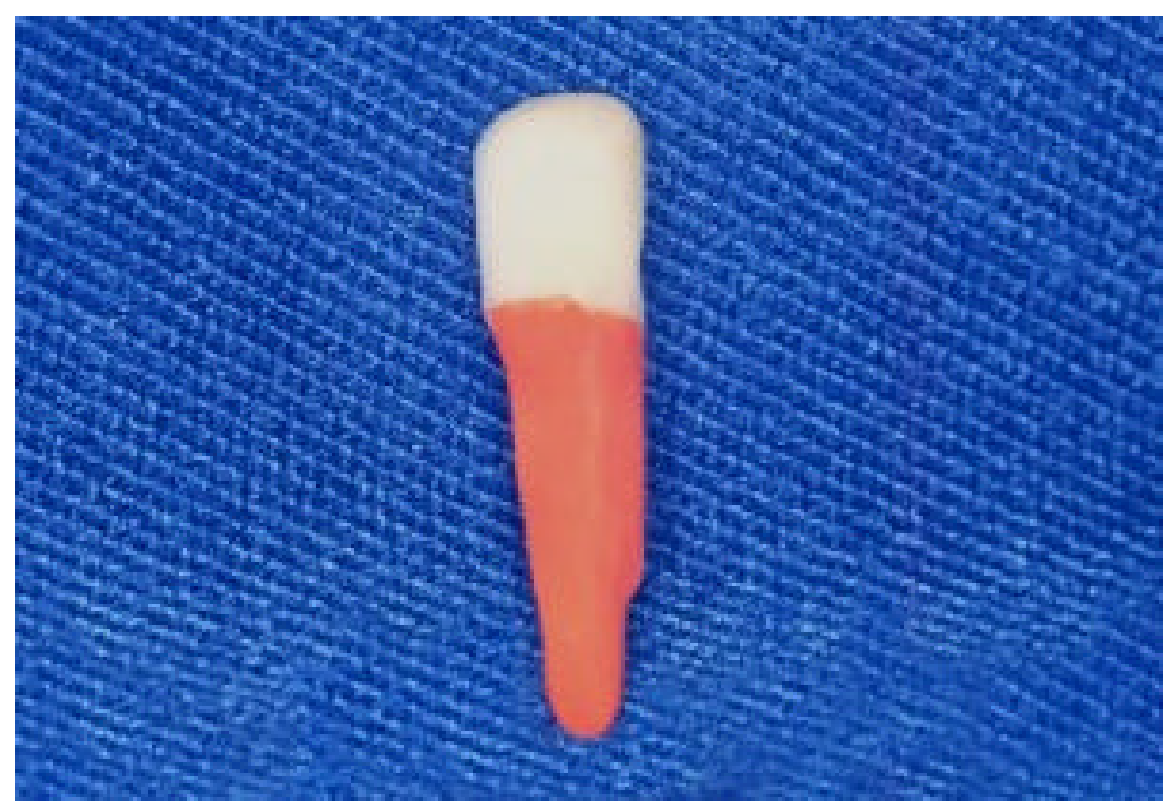

FIGURA 4.11 - Evidenciador de contatos aplicado à porção radicular do pino dentário

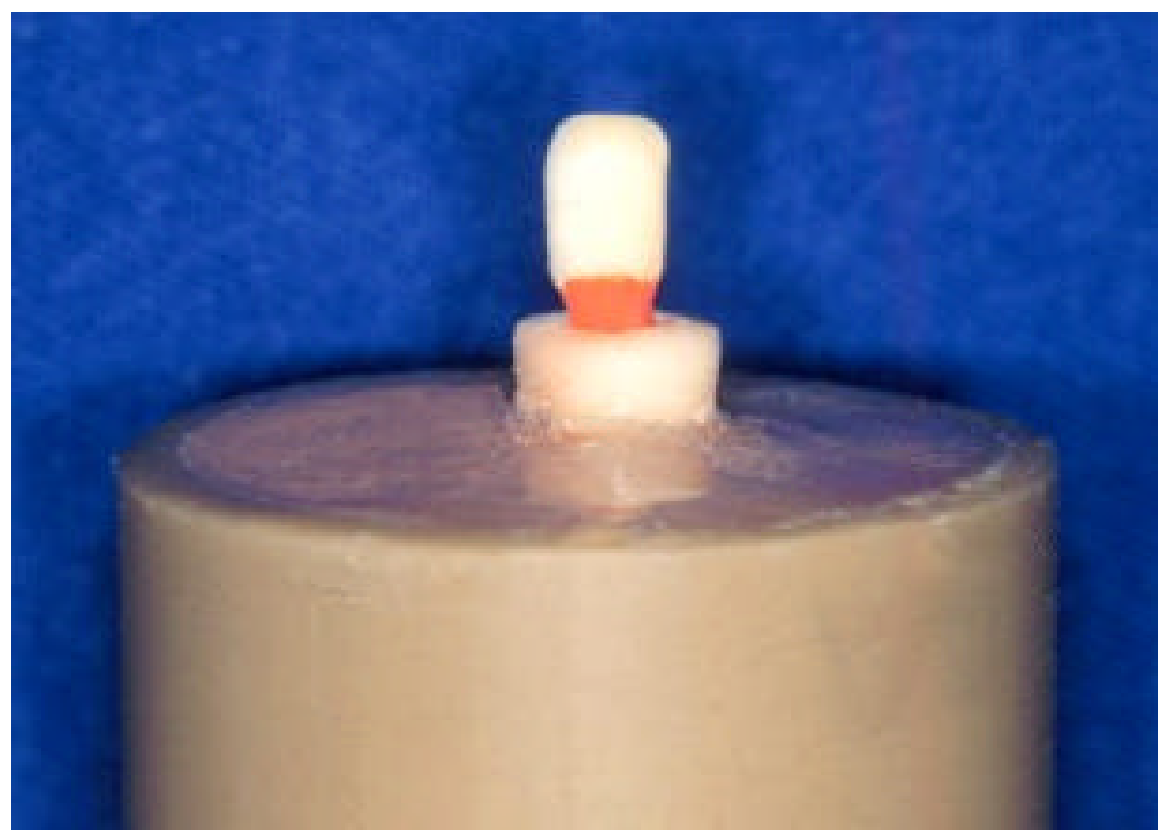

FIGURA 4.12 - Pino dentário sendo inserido no conduto radicular nota-se a falta de de adaptação do pino 


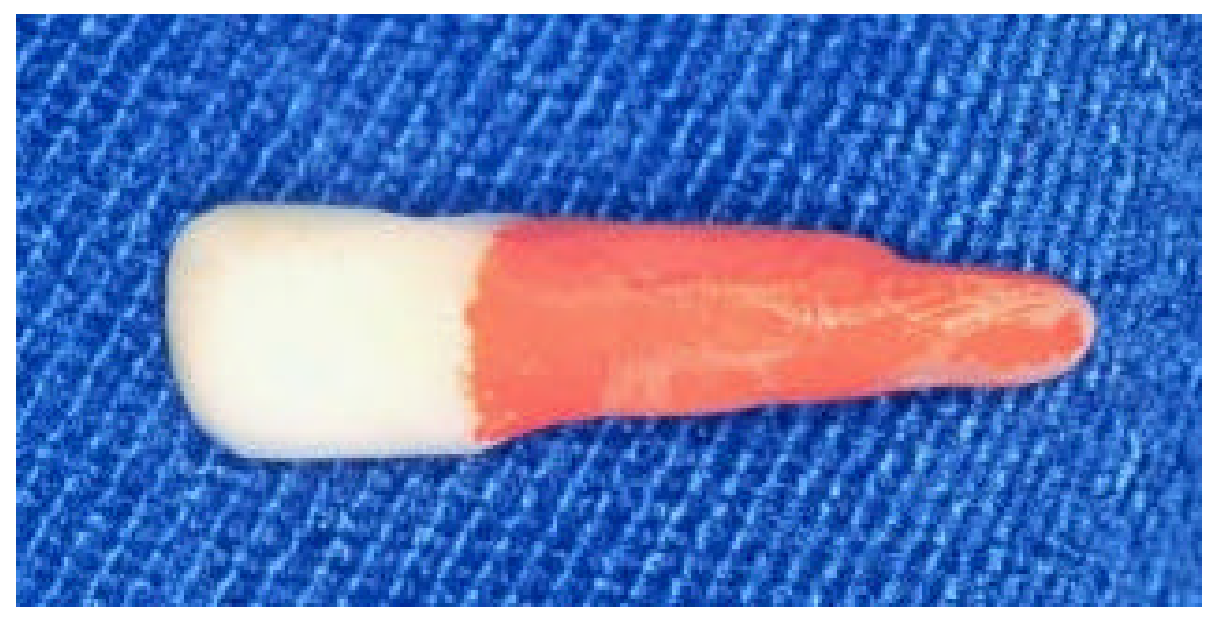

FIGURA 4.13 - Regiões de desadaptação do pino dentário evidenciadas após a sua prova no conduto radicular

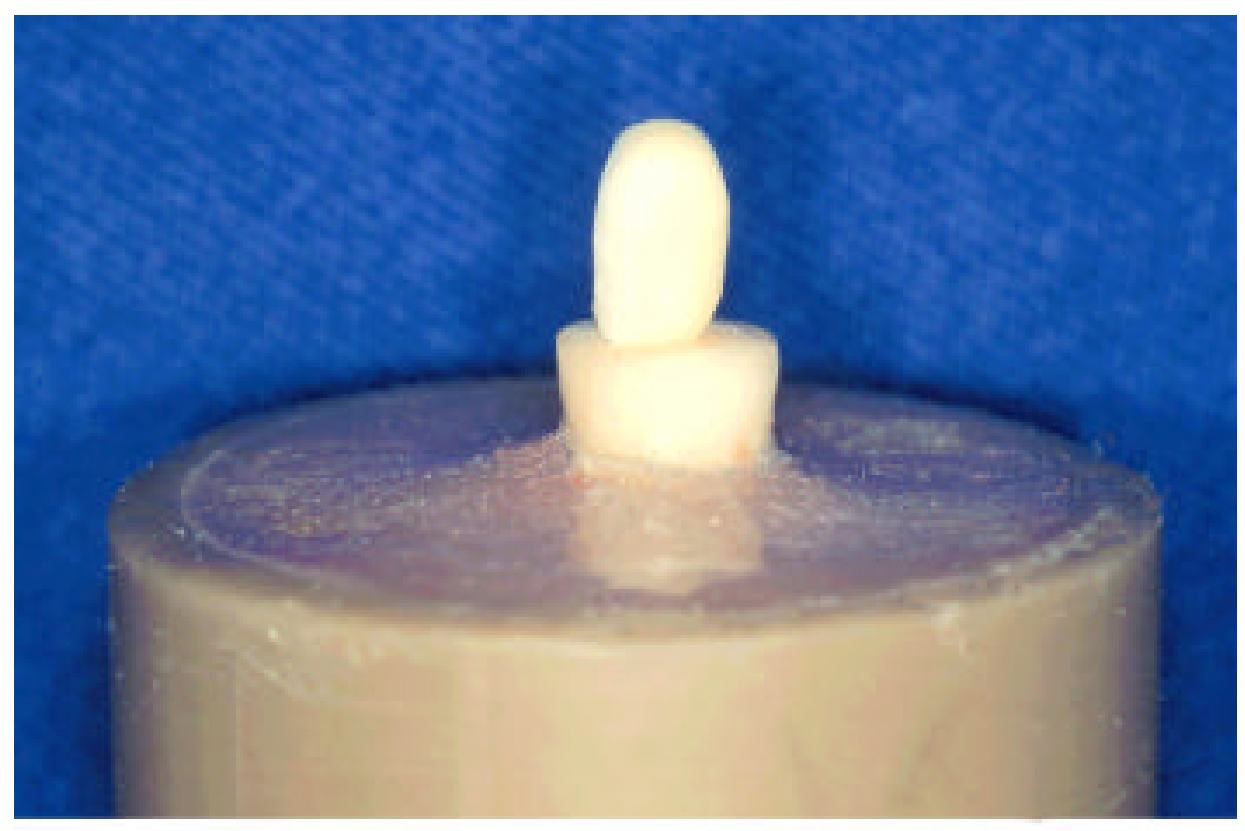

FIGURA 4.14 - Completa adaptação do pino dentário após desgaste das áreas evidenciadas

As dimensões dos pinos deste grupo também foram de $12 \mathrm{~mm}$ de comprimento ( $8 \mathrm{~mm}$ de comprimento intra-radicular e $4 \mathrm{~mm}$ de altura coronária) e aproximadamente $3 \mathrm{~mm}$ de diâmetro na porção coronária. O conduto do pino dentário foi obturado com cimento resinoso. Inicialmente este conduto era limpo 
com limas endodônticas, irrigado com hipoclorito de sódio a $1 \%$ e seco com cones de papel absorvente. Foi executado no interior do pino um condicionamento ácido por 60 segundos, aplicado o sistema adesivo Prime e Bond 2.1 associado ao Self Cure Activator (para permitir utilização de forma dual) e, com o auxílio de uma broca lentulo, o conduto foi preenchido com cimento resinoso Enforce com Flúor.

Para cimentação do pino e confecção da porção coronária do núcleo, foram empregados o mesmo material e as mesmas técnicas que para o grupo 2 .

\subsubsection{Preparo dos corpos de prova do grupo 4}

O grupo 4 consistiu de 15 caninos superiores tratados endodonticamente, com condutos amplamente alargados e restaurados com pinos dentários escalonados, confeccionados a partir de caninos inferiores hígidos e hidratados.

O preparo do conduto radicular foi executado de forma escalonada (com três degraus), constituindo o grupo denominado amplamente alargado. Utilizou-se inicialmente a ponta diamantada 1016HL, que penetrava $8 \mathrm{~mm}$ no conduto. A seguir, introduzia-se a ponta diamantada 3017HL no conduto até a profundidade de $5 \mathrm{~mm}$, confeccionando o degrau intermediário. Finalmente, para confecção do nível mais cervical, com profundidade de $3 \mathrm{~mm}$, utilizava-se a ponta diamantada 3018, que possui diâmetro de 3mm; neste degrau cervical, a espessura final das paredes do conduto preparado era de aproximadamente 0,5mm. Esta espesssura era conferida por espessímetro. O desgaste interno das raízes do grupo 4 está representado na Figura 4.3. Para confirmar a profundidade de penetração de cada ponta, foi empregada sonda periodontal e marcações nas hastes destas pontas.

Devido à reduzida espessura das paredes radiculares no terço cervical, após o preparo as raízes eram analisadas com uma lupa com quatro vezes de aumento para verificar a presença de eventuais trincas, sendo neste caso desprezadas.

O material e as técnicas utilizados para confecção e adaptação do pino no interior do canal radicular, bem como para cimentação do pino e confecção da porção coronária do núcleo foram idênticos àqueles acima descritos para o grupo 3. 
Na Figura 4.15 pode-se observar o preparo da porção radicular de um pino dentário do grupo 4.

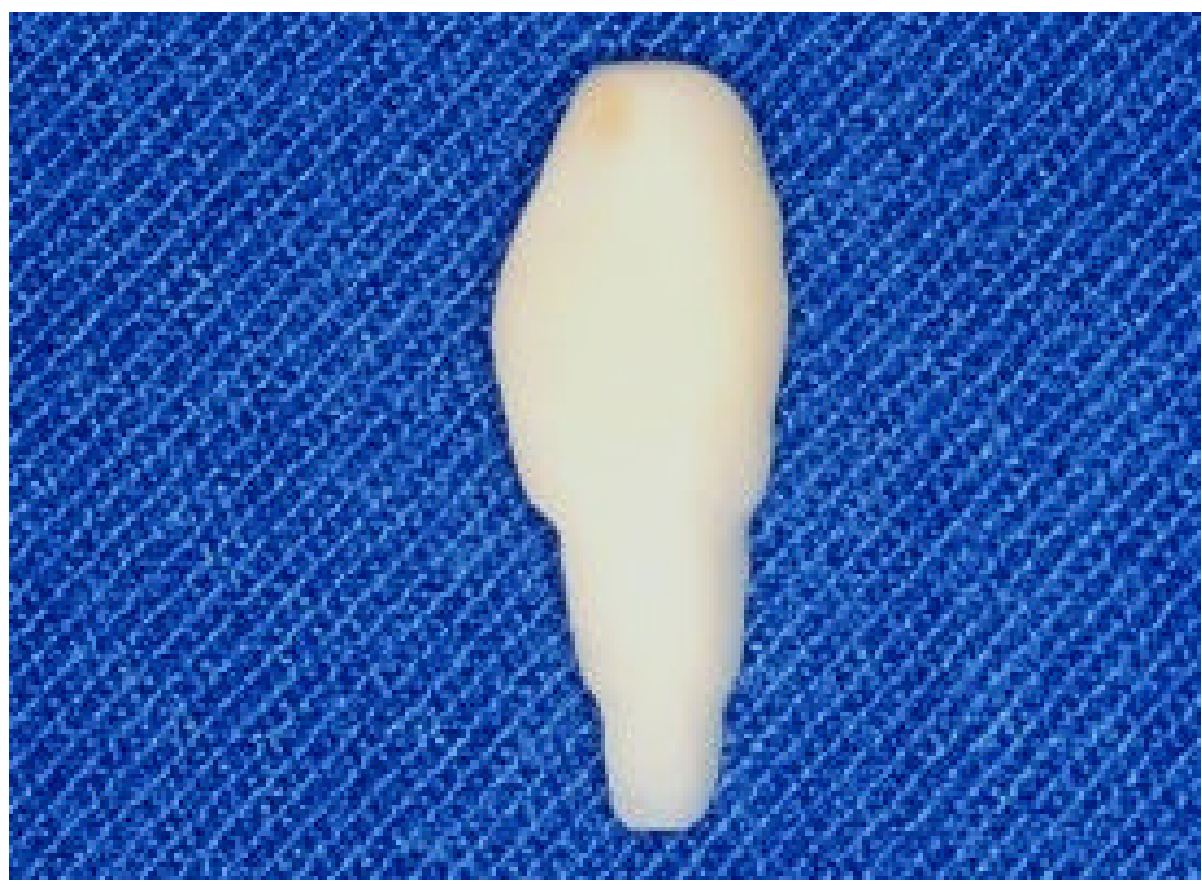

FIGURA 4.15- Preparo da porção radicular de pino dentário do grupo 4

\subsubsection{Teste de resistência à fratura}

Os testes de resistência à fratura sob compressão foram executados 24 horas após a confecção dos núcleos, período em que os corpos de prova foram mantidos em umidade absoluta (água destilada).

A resistência à fratura foi determinada em uma máquina de ensaios universal Kratos (Dinamômetros Kratos Ltda., modelo K-2000MP - São Paulo Brasil) através de carregamento de compressão. As condições do teste foram ajustadas para simular a situação in vivo.

Os corpos de prova foram acoplados à máquina de ensaios e os dentes foram submetidos à carga estática progressiva, à velocidade de $0,5 \mathrm{~mm} / \mathrm{min}$, utilizando uma célula de carga de 100kgf (célula $\mathrm{n}^{\circ} 2$ ).

O ponto de aplicação da força foi sempre o mesmo em todos os corpos de prova, na porção palato-incisal, assegurando assim que a distribuição das cargas fosse sempre semelhante e na mesma direção. A extremidade da ponta ativa 
utilizada para a aplicação da força compressiva era achatada e biselada, adaptandose à porção palatina do corpo de prova.

Um dispositivo especial acoplado à porção inferior da máquina de ensaios permitiu a colocação do corpo de prova durante a execução dos testes de forma que o núcleo ficasse posicionado em uma inclinação de $45^{\circ}$ em relação ao plano horizontal ( $135^{0}$ em relação ao longo eixo do dente), fazendo com que a carga de compressão fosse aplicada simulando uma condição clínica real de oclusão do tipo classe I. Na porção superior da máquina de ensaios, foi adaptada a ponta ativa que imprimiu a força de compressão. A máquina de ensaios foi programada de forma que a carga era automaticamente descontinuada (paralisação da máquina) quando o sistema de alguma forma falhasse - deslocamento ou fratura do núcleo ou fratura da raiz.

$\mathrm{Na}$ Figura 4.16 é possível observar como foi realizado o teste de resistência à fratura sob cargas compressivas na máquina de ensaios.

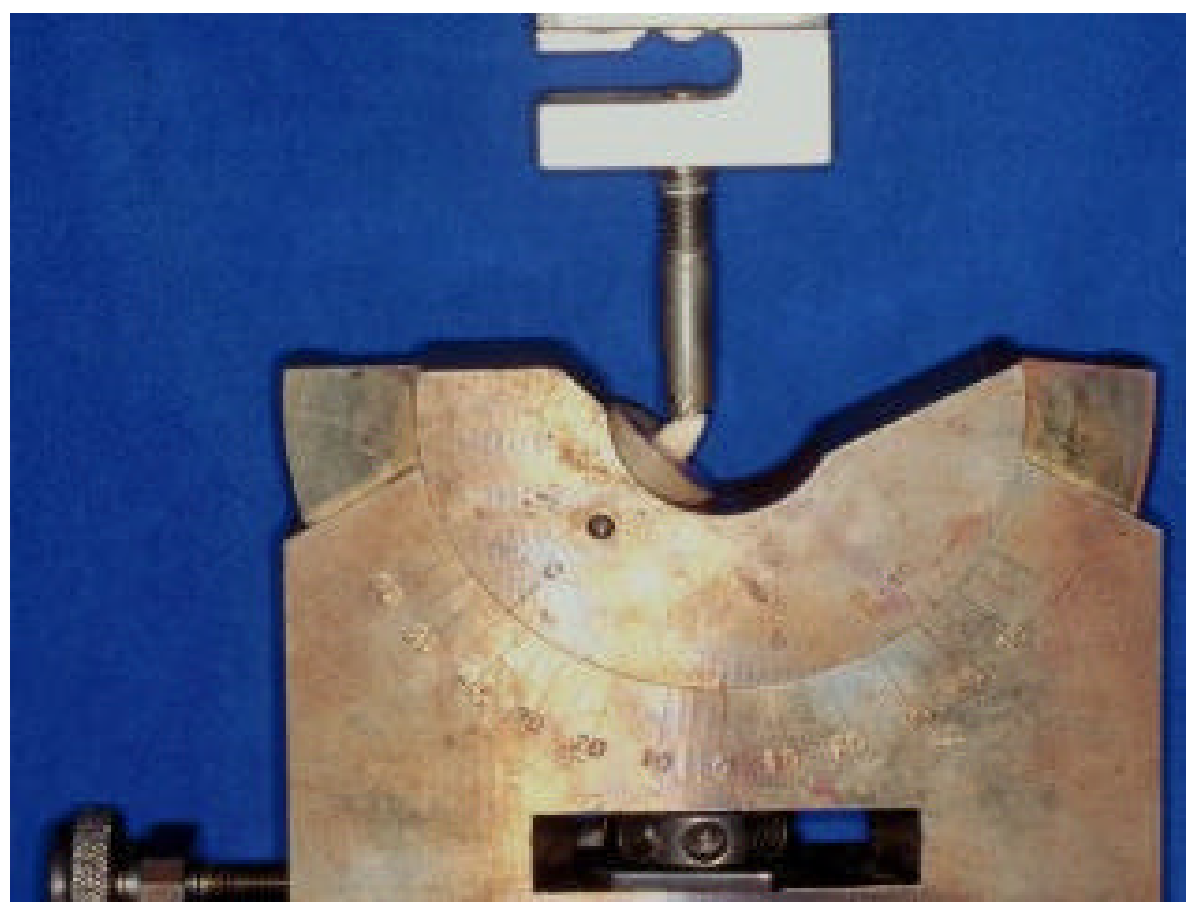

FIGURA 4.16 - Carregamento de compressão formando um ângulo de $45^{0}$ em relação ao plano horizontal $\left(135^{0}\right.$ em relação ao longo eixo do dente) 


\subsubsection{Registro do limiar de falha}

Limiar de falha é a carga máxima que o corpo de prova pode suportar antes que ocorra algum tipo de falha (deslocamento/fratura do núcleo ou fratura da raiz).

Para todos os corpos de prova, tanto a carga necessária para causar a falha (limiar de falha) quanto o modo como esta ocorreu foram registrados.

O limiar de falha e o gráfico de aplicação das forças eram emitidos no monitor do computador acoplado à maquina universal de ensaios e posteriormente impressos.

\subsubsection{Análise estatística}

Os resultados obtidos durante os testes de resistência à fratura nos quatro grupos experimentais foram organizados para tratamento estatístico. Foi empregada análise descritiva, com o uso de tabelas, gráficos e parâmetros de média e desvio-padrão.

Para comparação das médias, foi utilizada a Análise de Variância (ANOVA) a um critério, modelo fixo. Como a Análise de Variância demonstrou diferença estatisticamente significante entre os grupos estudados, utilizou-se o teste de Tukey para comparações múltiplas.

Em todas as induções estatísticas, foi adotado nível de significância de 5\%. O programa utilizado para análise estatística foi o Statistica for Windows versão 5.0. 


\section{RESULTADOS}

Os valores (em kgf) obtidos para cada corpo de prova após os ensaios de resistência à fratura sob compressão na máquina de ensaios universal, suas respectivas médias e desvios padrão são apresentados na Tabela 5.1.

TABELA 5.1 - Valores individuais de resistência à fratura (em kgf) para cada corpo de prova, médias e respectivos desvios padrão para cada grupo experimental

\begin{tabular}{ccccc}
\hline $\begin{array}{c}\text { CORPO DE } \\
\text { PROVA }\end{array}$ & GRUPO 1 & GRUPO 2 & GRUPO 3 & GRUPO 4 \\
\hline 1 & 66,60 & 59,25 & 91,05 & 43,50 \\
2 & 51,35 & 48,75 & 31,75 & 44,65 \\
3 & 46,45 & 53,20 & 60,50 & 23,65 \\
4 & 36,00 & 57,80 & 39,00 & 68,50 \\
5 & 58,75 & 55,35 & 73,55 & 45,40 \\
6 & 37,70 & 34,65 & 57,40 & 59,10 \\
7 & 31,75 & 56,05 & 64,50 & 45,75 \\
8 & 48,05 & 44,60 & 61,05 & 46,60 \\
9 & 39,05 & 56,15 & 41,35 & 43,15 \\
10 & 41,60 & 62,80 & 58,60 & 42,00 \\
11 & 51,20 & 49,30 & 45,40 & 50,10 \\
12 & 41,50 & 47,75 & 73,30 & 39,35 \\
13 & 50,20 & 49,65 & 48,90 & 53,65 \\
14 & 32,20 & 81,70 & 53,80 & 52,85 \\
15 & 49,10 & 42,50 & 80,00 & 60,45 \\
\hline MÉDIA & 45,46 & 53,30 & 58,67 & 47,91 \\
DESVIO PADRÃO & 9,72 & 10,66 & 16,23 & 10,45 \\
\hline & & & & \\
\hline
\end{tabular}

Grupo 1 - Pino de fibras de polietileno com preparo convencional do conduto

Grupo 2 - Pino dentário com preparo convencional do conduto

Grupo 3 - Pino dentário com conduto medianamente alargado

Grupo 4 - Pino dentário com conduto amplamente alargado 
Pode-se observar as médias de resistência à fratura e desvios padrão para cada grupo experimental na Tabela 5.2 e na Figura 5.1.

TABELA 5.2 - Médias de resistência à fratura (em kgf) e respectivos desvios padrão em cada grupo experimental

\begin{tabular}{ccc}
\hline GRUPOS & MÉDIA & DESVIO PADRÃO \\
\hline 1 & 45,46 & 9,72 \\
2 & 53,30 & 10,66 \\
3 & 58,67 & 16,23 \\
4 & 47,91 & 10,45 \\
\hline
\end{tabular}

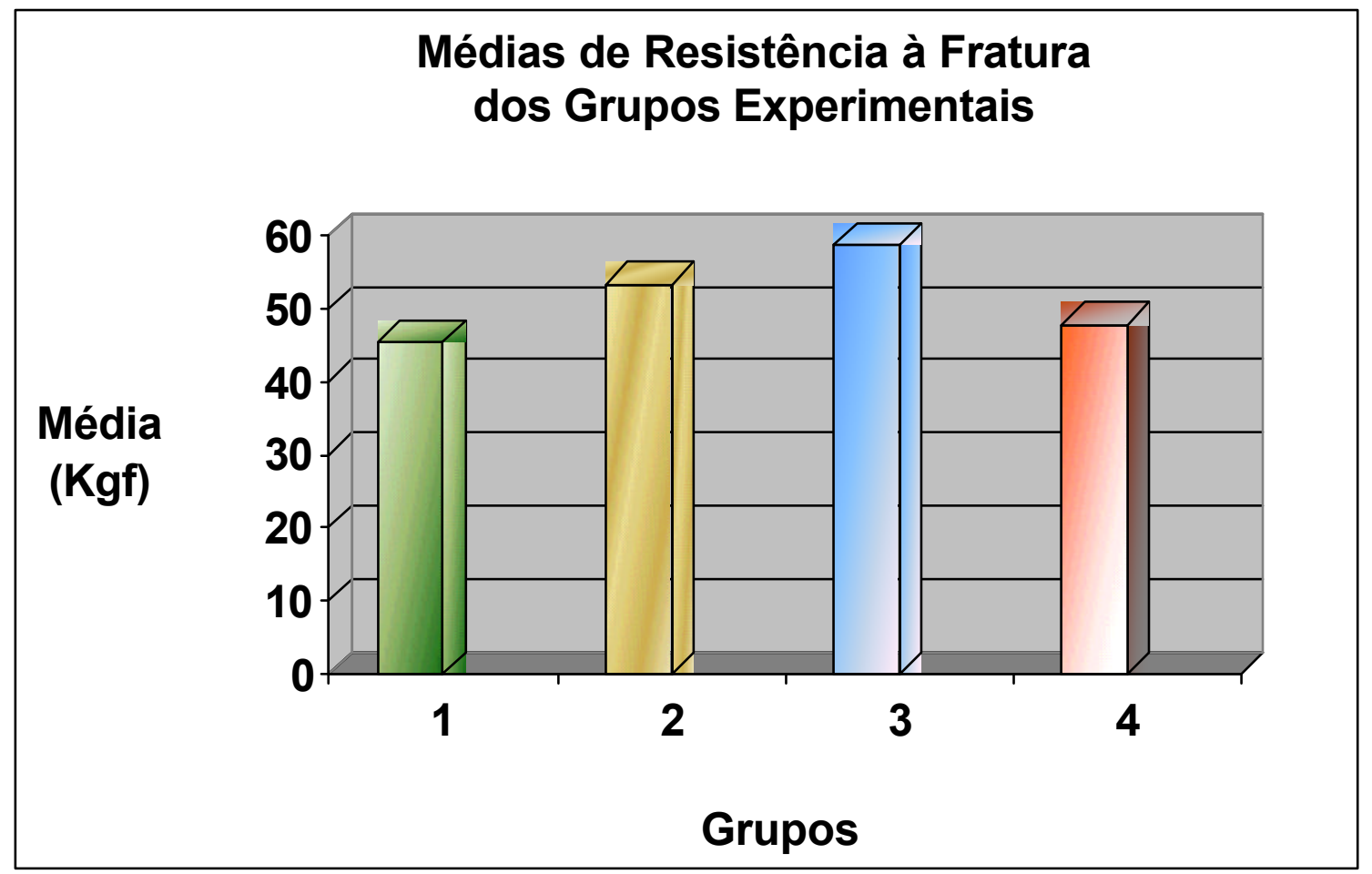

FIGURA 5.1 - Gráfico representativo das médias de resistência à fratura dos grupos experimentais 
Os valores de resistência à fratura obtidos após os testes foram submetidos à Análise de Variância a um critério (ANOVA), a qual demonstrou existir diferença estatisticamente significante entre os grupos (Tabela 5.3). Finalmente, foi aplicado o teste de Tukey para comparações múltiplas, visando localizar as diferenças entre os grupos experimentais (Tabela 5.4).

O teste de TUKEY revelou a existência de diferença estatisticamente significante entre o grupo 1 e 3 , não encontrando diferenças significantes entre os demais grupos quando comparados entre si.

TABELA 5.3 - Resultados da Análise de Variância a um critério (ANOVA) para o ensaio de resistência à fratura das raízes

\begin{tabular}{cccccc}
\hline $\begin{array}{c}\text { Graus de Liberdade } \\
\text { Efeito }\end{array}$ & $\begin{array}{c}\text { Quadrado } \\
\text { Médio }\end{array}$ & $\begin{array}{c}\text { Graus de } \\
\text { Liberdade }\end{array}$ & $\begin{array}{c}\text { Quadrado } \\
\text { Médio }\end{array}$ & F & $\begin{array}{c}\text { Probabilidade } \\
\text { (p) }\end{array}$ \\
\hline 3 & Efeito & Erro & Erro & & \\
\hline & 521,4935 & 56 & 145,2525 & 3,590255 & $0,019108^{*}$ \\
\hline
\end{tabular}

* diferença estatisticamente significante $(\mathrm{p}<0,05)$

TABELA 5.4 - Teste de TUKEY para comparações múltiplas

\begin{tabular}{cc}
\hline COMPARAÇÕES & PROBABILIDADE (p) \\
\hline Grupo 1 x Grupo 2 & 0,290099 n.s. \\
Grupo 1 x Grupo 3 & $0,019998 *$ \\
Grupo 1 x Grupo 4 & 0,942505 n.s. \\
Grupo 2 x Grupo 3 & 0,615907 n.s. \\
Grupo 2 x Grupo 4 & 0,614486 n.s. \\
Grupo 3 x Grupo 4 & 0,080233 n.s. \\
\hline
\end{tabular}

n.s. diferença estatisticamente não-significante

* diferença estatisticamente significante 
$\mathrm{Na}$ Tabela 5.5, é apresentado o padrão de fratura que ocorreu nos grupos experimentais (os terços radiculares foram considerados a cada $5 \mathrm{~mm}$ ).

TABELA 5.5 - Padrão de fratura observado para os grupos experimentais

\begin{tabular}{ccccc}
\hline $\begin{array}{c}\text { PADRÃO DE } \\
\text { FRATURA }\end{array}$ & $\begin{array}{c}\text { GRUPO 1 } \\
(\mathbf{n}=\mathbf{1 5})\end{array}$ & $\begin{array}{c}\text { GRUPO 2 } \\
(\mathbf{n}=\mathbf{1 5})\end{array}$ & $\begin{array}{c}\text { GRUPO 3 } \\
(\mathbf{n}=\mathbf{1 5})\end{array}$ & $\begin{array}{c}\text { GRUPO 4 } \\
(\mathbf{n}=\mathbf{1 5})\end{array}$ \\
\hline Terço cervical da raiz & $2(13,3 \%)$ & $7(46,6 \%)$ & $6(40 \%)$ & $10(66,6 \%)$ \\
Terço médio da raiz & - & $1(6,6 \%)$ & $1(6,6 \%)$ & $5(33,3 \%)$ \\
$\begin{array}{c}\text { Fratura do pino e/ou da porção } \\
\text { coronária do núcleo }\end{array}$ & $13(86,6 \%)$ & $7(46,6 \%)$ & $8(53,3 \%)$ & - \\
\hline
\end{tabular}

Na Figura 5.2, pode-se observar uma representação gráfica do padrão de fratura para os grupos experimentais.

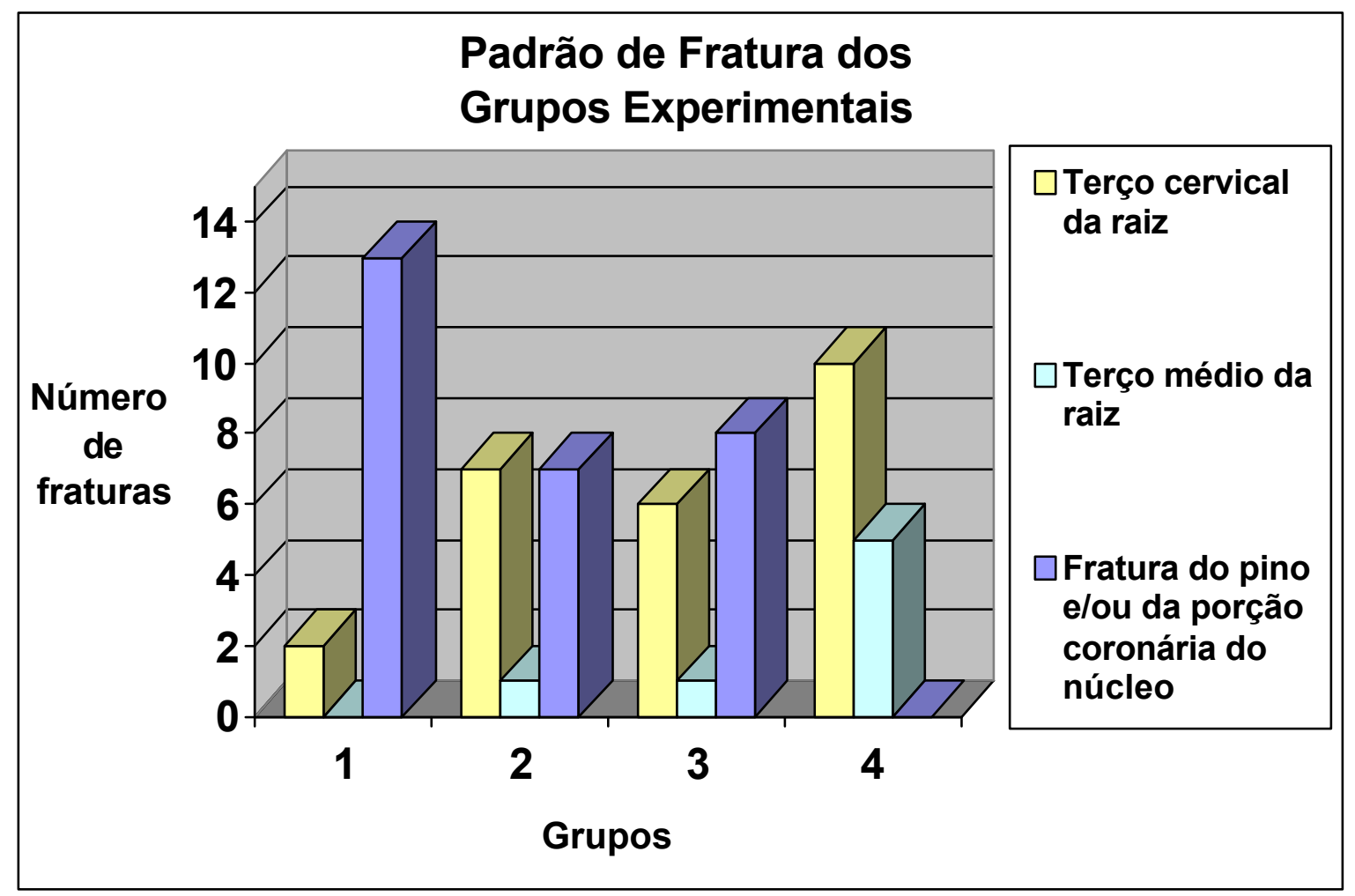

FIGURA 5.2 - Representação gráfica do padrão de fratura observado nos grupos experimentais 
Conforme representado na Tabela 5.5 e na Figura 5.2, no grupo 1 (pinos de fibras de polietileno) o tipo de fratura mais usual foi a fratura da porção coronária do núcleo, mais especificamente da resina composta, sendo que raramente ocorreu fratura radicular ao nível do terço cervical (somente em dois corpos de prova) e nenhuma fratura ao nível do terço médio.

Nos grupo 2 e 3, o tipo e a porcentagem de fraturas radiculares foram similares (somando-se falhas radiculares no terço cervical e médio), bem como foi semelhante a quantidade de fraturas da porção coronária do núcleo e/ou do pino.

No grupo 4, 100\% das raízes sofreram fratura, havendo inclusive a maior quantidade de fraturas ao nível do terço médio da raiz, em número significantemente mais expressivo que nos demais grupos. 


\section{DISCUSSÃO}

A reconstrução de elementos dentários tratados endodonticamente normalmente é um procedimento complexo, pois é bastante comum que toda ou uma extensa porção de sua estrutura coronária tenha sido perdida por lesões cariosas, erosão, abrasão, restaurações anteriores, traumas e pelo próprio acesso para o tratamento endodôntico ${ }^{84,105,121}$.

Em 1967, BARABAN ${ }^{5}$ afirmou que dentes despolpados são mais frágeis devido à desidratação e sugeriu métodos de reforço como os núcleos metálicos fundidos, associados ou não a pinos dentinários auxiliares, núcleos divididos e pinos metálicos pré-fabricados. No entanto, TRABERT; CAPUTO; $\mathrm{ABOU} \mathrm{RASS}^{125}$, em 1978, não encontraram diferenças na resistência à fratura entre dentes não tratados e dentes tratados endodonticamente.

GUZY; NICHOLLS ${ }^{48}$, em 1979, observaram que dentes despolpados pareciam mais friáveis que dentes vitais, tendo em vista sua fratura freqüente durante a mastigação, mas não conseguiram encontrar diferenças no padrão de fratura, localização da fratura ou resistência à fratura entre dentes com ou sem pinos metálicos. Foi ressaltado ainda que dentes tratados endodonticamente restaurados com núcleos de diferentes materiais e desenhos provavelmente exibirão resistência à fratura similar quando estrutura dentária abundante permanece. TROPE; MALTZ; TRONSTAD ${ }^{127}$, em 1985, mencionaram também a perda de hidratação e de elasticidade da dentina em dentes despolpados.

SORENSEN; MARTINOFF ${ }^{117}$, em 1984, suspeitavam que a desidratação da dentina diminuía a resistência à fratura de dentes desvitalizados, que deveriam por este motivo serem reforçados com pinos; porém, ao avaliarem 1273 dentes tratados endodonticamente com ou sem pinos metálicos, não observaram aumento da resistência à fratura nos dentes com pinos.

Foi aproximadamente a partir desta época que se observou e se comprovou definitivamente que os núcleos metálicos fundidos, assim como os vários sistemas de pinos metálicos pré-fabricados utilizados como meio de retenção para núcleos de preenchimento, não eram capazes de promover reforço à estrutura dentária remanescente, podendo até mesmo torná-la mais susceptível à fratura 
4,48,51,120,125,127; isto já havia sido comentado, embora não devidamente comprovado, desde 1976 por CAPUTO; STANDLEE ${ }^{23}$.

Começaram a surgir, principalmente a partir da década de 1990, diferentes materiais com a finalidade de substituir o metal na confecção dos núcleos intra-radiculares, entre os quais se destacaram as fibras de carbono ${ }^{14,18,28-}$ $31,37,39,40,41,44,52,58,65,76,77,80,88,92,99,100,106,120$, as fibras de polietileno $14,34,37,41,56,59,62,63,64,82,85,107,112,120,123$ e as fibras de vidro ou de quartzo 3,14,35,37,41,45,63,85,120; um dos principais objetivos almejados por estes materiais era a similaridade com o módulo de elasticidade da dentina ${ }^{89}$.

Ainda nesta década, observou-se que em raízes com alargamento excessivo do conduto devido a cáries extensas, uso prévio de núcleos com largo diâmetro, iatrogenias durante a abertura da câmara coronária, sobreinstrumentação endodôntica, rizogênese incompleta, reabsorção interna ou anomalias de desenvolvimento, a restauração com núcleos convencionais pode tornar-se difícil ou mesmo inviáve ${ }^{54,64,73}$. Núcleos metálicos fundidos agiriam como cunha, precipitando a fratura destas raízes fragilizadas, enquanto pinos pré-fabricados adaptar-se-iam imprecisamente aos condutos alargados e ficariam envolvidos por quantidades excessivas de cimento ${ }^{54,64,73}$. Uma forma adequada de reforço para raízes com paredes muito finas é fundamental, pois estão mais propensas a fraturar na cimentação dos pinos ou durante atividades funcionais e parafuncionais $64,72,73,93,104,124$.

Para raízes nestas condições e na tentativa de buscar reforço evitando sua perda precoce, diferentes materiais foram sugeridos e testados, como ionômero de vidro ${ }^{4,113,126}$ e resina composta ${ }^{12,72,73,78,93,104,113,127}$. Recentemente, tem-se proposto a confecção de pinos dentários, a partir de dentes naturais obtidos em bancos de dentes $^{11-13,24,25,46,55,94,128,129,134}$.

É de extrema importância a obtenção de um sistema de núcleos com propriedades físico-mecânicas adequadas, preferencialmente similares às da estrutura dentária perdida, que atue como dentina artificial, reforçando raízes estruturalmente enfraquecidas. Como é de conhecimento geral, ainda hoje a maioria dos profissionais opta pela exodontia destes elementos por temer um prognóstico adverso a longo prazo $^{73,93}$. Entretanto, muitas vezes a destruição radicular interna está restrita à 
porção cervical do conduto, enquanto a porção apical possui adequado suporte dentinário $^{73}$.

Tem-se tentado obter um sistema de restauração em monobloco, isto é, um único complexo biomecânico através da adesão entre estruturas heterogêneas (remanescente dentário, agente cimentante, pino e material de preenchimento) e pelo emprego de materiais com propriedades f́sicas semelhantes às da dentina; desta forma, seria possível alcançar um reforço real da estrutura dentária remanescente $\mathrm{r}^{30,31,40,41,54,56,58,59,63,99,123}$. Materiais com tais características seriam especialmente úteis quando nenhuma dentina permanece supragengivalmente, de forma a permitir obtenção de uma férula extracoronária convencional - teoricamente, estes materiais adesivos permitiriam obtenção de um abraçamento interno ${ }^{120}$. Segundo STEWARDSON ${ }^{120}$, em 2001 e ESKITAÆIOĐLU; BELLI; KALKAN ${ }^{34}$, em 2002, a utilização de pinos com materiais menos rígidos que a dentina gera menor transferência de estresse para as estruturas radiculares e, se o material do pino é levemente menos resistente que a dentina, é provável que o pino frature antes que a raiz.

Vários autores sugeriram que o preenchimento com resina composta

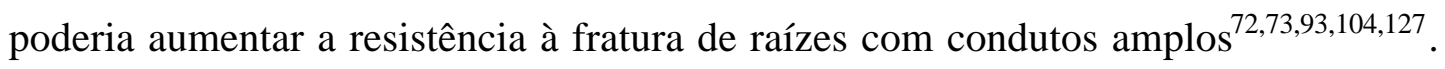
TROPE; MALTZ; TRONSTAD ${ }^{127}$, em 1985, indicaram esta técnica para restauração de dentes jovens tratados endodonticamente com rizogênese incompleta (condutos largos e paredes radiculares finas) e RABIE et al. ${ }^{93}$, em 1985, aplicaram esta proposta clinicamente em dentes imaturos, com bons resultados. A técnica foi aperfeiçoada por $\mathrm{LUI}^{73}$, em 1994, que utilizou um pino plástico fototransmissor para auxiliar na polimerização da resina composta em regiões mais profundas do conduto. SAUPE; GLUSKIN; RADKE ${ }^{104}$, em 1996, observaram a eficácia da resina composta em reforçar raízes estruturalmente comprometidas (com 0,5 a $0,75 \mathrm{~mm}$ de espessura das paredes radiculares), comparando raízes reforçadas com resina composta em relação a raízes onde foram cimentados núcleos metálicos fundidos em ouro tipo III. As raízes reforçadas mostraram resistência à fratura 50\% maior em relação aos sistemas sem reforço, sugerindo a vantagem do reforço com materiais que permitam adesão entre estrutrura radicular e material de reforço (complexo biomecânico único ou monobloco). Além disto, com a utilização de reforço não houve diferença 
significante na resistência à fratura entre núcleos com ou sem férula, possibilitando economia de estrutura dentária.

Já MARCHI ${ }^{78}$, em 1997, comparando raízes debilitadas restauradas com resina composta e pino metálico pré-fabricado em relação a raízes hígidas com pinos metálicos pré-fabricados, concluiu que a resina composta não foi capaz de recuperar totalmente a resistência original do dente à fratura. $\mathrm{O}$ valor de resistência à fratura obtido foi 13,36kgf para raízes debilitadas e 24,71kgf para raízes hígidas. Da mesma forma, SOARES ${ }^{113}$, em 1999, encontrou maiores valores de resistência à fratura para raízes hígidas com núcleo metálico fundido (71,6kgf), das quais 78,6\% fraturaram, do que para raízes debilitadas restauradas com resina composta $(40,1 \mathrm{kgf}$ para resina composta fotopolimerizável Z100 e 36,2kgf para resina composta autopolimerizável Bisfil II), das quais $100 \%$ fraturaram. BONILLA ${ }^{12}$, em 2001, obteve resistência à fratura menor no grupo de raízes debilitadas restauradas com resina composta e núcleo metálico fundido $(53,98 \mathrm{kgf})$ em relação a outras formas de restauração: raízes amplamente destruídas reconstruídas com pinos dentários (76,35kgf), dentes com preparo convencional do conduto e núcleo metálico fundido (87,59kgf) ou raízes amplamente destruídas com núcleo metálico fundido (57,64kgf).

Fibras de polietileno vêm sendo sistematicamente recomendadas para confecção de núcleos de preenchimento ${ }^{14,34,37,41,56,59,63,64,82,85,107,112,123}$. As mais indicadas são aquelas com tratamento superficial por plasma de gás frio, que permite união química aos sistemas adesivos e resinas compostas ou acrílicas 32,38,59,64,82,101,102. A arquitetura entrelaçada também é recomendada, pois possibilita reforço multidirecional da resina e melhor distribuição do estresse $\mathrm{e}^{14,41,59,82,101,123}$. Um material com estas características é o Ribbond, utilizado para confecção dos corpos de prova do grupo 1, em raízes com preparo convencional do conduto, que apresentaram resistência média à fratura de 45,46kgf, conforme demonstrado na Tabela 5.1.

As principais vantagens do material seriam: (1) estrutura entrelaçada, que auxilia a manter sua integridade estrutural e proporciona reforço multidirecional da resina, aumentando sua resistência à fratura ${ }^{37,38,56,82,101,123}$; (2) união química à resina composta, graças ao tratamento eletroquímico da superfície com gás plasma $^{32,38,59,64,82,95,102,123}$; (3) alta maleabilidade, devido à arquitetura entrelaçada das 
fibras e ao baixo módulo da fibra na compressão ${ }^{37,38,41,62,82,101}$; (4) excelente estética $^{14,37,38,56,59,62,82,101,123}$; (5) flexibilidade, que permite dissipação de forças funcionais ou parafuncionais, minimizando o risco de fratura $\operatorname{radicular}^{62,82}$; (6) preparo conservador - devido a suas propriedades adesivas, o alargamento adicional do conduto é desnecessário ${ }^{41,62}$; (7) quimicamente inerte à maioria dos solventes, ácidos ou substâncias alcalinas ${ }^{101}$; (8) as fibras atuam como transmissores ópticos, auxiliando a conduzir a luz do fotopolimerizador ${ }^{37} ;(9)$ biocompatibilidade $^{123} ;(10)$ técnica simples e em sessão única, sem custo laboratorial ${ }^{56,59,123}$; (11) fácil remoção $^{62} ;(12)$ baixa sorção de água ${ }^{82,101}$.

As desvantagens mais relevantes do Ribbond são: (1) técnica sensível (protocolo adesivo); (2) necessidade de estocar os materiais utilizados.

Os pinos de fibras de polietileno estão bem indicados para raízes com condutos amplos e paredes enfraquecidas ${ }^{54,64,85}$, pois formariam um bloco único com a raiz, pela união de materiais adesivos entre si, reforçando a raiz e impedindo a propagação de trincas já existentes nas paredes até o periodonto ${ }^{34,54}$.

Apesar de toda a padronização buscada na metodologia, observa-se considerável variação de resultados nos corpos de prova do grupo 1, variando de $31,75 \mathrm{kgf}$ (corpo de prova 7 ) até $66,60 \mathrm{kgf}$ (corpo de prova 1); talvez isto se deva principalmente à dificuldade em padronizar a proporção entre fibras e cimento resinoso, bem como a distribuição das fibras no interior da resina. Além disto, as fibras de Ribbond, por não serem pré-impregnadas com a resina, necessitam que o adesivo seja aplicado imediatamente antes de sua utilização, sendo difícil confirmar se todas as fibras foram completamente impregnadas e havendo sempre algum risco de contaminação da superfície das fibras ${ }^{38}$. ELLAKWA et al. $^{32}$, em 2002, confirmou que é de fundamental importância uma adequada impregnação das fibras de polietileno para a maior resistência da resina composta por elas reforçada.

RAMOS JÚNIOR; RUNYAN; CHRISTENSEN ${ }^{95}$, em 1996, observaram que em barras de polimetilmetacrilato reforçadas com fibras de polietileno Ribbond a resistência à fratura foi $28 \%$ maior em relação a espécimes não reforçados. Observaram ainda que as fibras minimizaram a propagação de linhas de fratura, fenômeno que foi também notado na presente pesquisa, pois usualmente a fratura não se propagava além das fibras. 
KARNA $^{62}$, em 1996, publicou os resultados de um estudo piloto no qual testou a resistência à fratura de cinco dentes tratados endodonticamente e restaurados com pinos de fibras de polietileno Ribbond. Obteve os seguintes resultados: incisivo superior: 45kgf; incisivo inferior: 44kgf; pré- molar inferior com a coroa removida: 63kf; pré-molar superior com a cúspide lingual removida: $122 \mathrm{kgf}$; terceiro molar inferior preparado para coroa total: 390kgf. Houve fratura das raízes do incisivo inferior e do molar, bem como da porção coronária em todos os espécimes, exceto no incisivo superior.

Em 1998, HOLLIS et al. ${ }^{52}$ compararam a resistência à fratura de incisivos centrais superiores preparados mas não restaurados em relação a vários sistemas restauradores, como: somente resina composta dual, sem pino; restauração com pinos de fibra de carbono; com pinos de fibra de carbono-quartzo; com pinos de fibras de polietileno Ribbond; com pinos cerâmicos; com pinos de aço inoxidável; com pinos de titânio. Confeccionaram a porção coronária com resina composta dual e submeteram os espécimes a cargas compressivas. Todos os núcleos, exceto aquele de Ribbond, exibiram resistência significantemente maior que aquela de resina composta sem pino, sendo os valores em ordem decrescente: aço inoxidável 69,13kgf; titânio puro - 65,87kgf; fibra de carbono - 64,75kgf; liga de titânio 63,52kgf; cerâmico - 62,91kgf; fibra de carbono com quartzo - 57,92kgf e igual valor para o incisivo preparado sem pino. A resistência do núcleo de Ribbond (40,38kgf) foi semelhante à da resina sem pino. Nos pinos de Ribbond, assim como nesta pesquisa, a reconstrução coronária foi lentamente esmagada. Com pinos metálicos houve mais fraturas radiculares (47\%) do que com não-metálicos (33\%). Com o pino de Ribbond não houve nenhuma fratura dentária. Concluiu-se que todos os sistemas testados exibiram desempenho clinicamente aceitável.

SIRIMAI; RIIS; MORGANO ${ }^{112}$, em 1999, avaliaram a resistência à fratura e padrão de falhas de raízes despolpadas com diferentes sistemas de núcleos: núcleos metálicos fundidos; pinos de titânio com diâmetros iguais ou menores que os do conduto; núcleos de fibras de polietileno Ribbond e resina fotopolimerizável; pinos de titânio de diâmetro menor que o do conduto envolvidos por Ribbond. Os valores encontrados para os diferentes sistemas foram: Grupo 1 - núcleos metálicos fundidos (29,43kgf); Grupo 2 - pinos de titânio com 1,6mm de diâmetro (25,97kgf); 
Grupo 3 - núcleos de fibras de polietileno Ribbond e resina composta (12,95kgf); Grupo 4 - pino de titânio com 1,2mm de diâmetro envolvido por Ribbond (22,26kgf); Grupo 5 - pino de titânio com 1,25 mm de diâmetro envolvido por Ribbond (23,82kgf); Grupo 6 - pino de titânio com 1,25mm de diâmetro (20,53kgf). Exceto no grupo 1, as porções coronárias dos núcleos foram construídas com resina composta. Nos grupos 4, 5 e 6, os pinos eram de diâmetros menores que o do conduto. Observaram que a resistência à fratura do núcleo de Ribbond sem pino metálico foi menor que nos demais sistemas. O envolvimento com Ribbond dos pinos de diâmetro menor que o do conduto aumentou a resistência em relação à utilização destes pinos isoladamente e também em relação à utilização unicamente de fibras de polietileno e resina composta, além do que foram evidenciadas menos fraturas radiculares que com núcleos metálicos fundidos.

ESKITAґIOĐLU; BELLI; KALKAN ${ }^{34}$, em 2002, compararam núcleos de preenchimento com fibras de polietileno Ribbond e cimento resinoso com núcleos metálicos fundidos. Não houve diferença estatisticamente significante da resistência à fratura entre núcleos metálicos fundidos $(37,7 \mathrm{kgf})$ e núcleos de Ribbond $(33,4 \mathrm{kgf})$. Já o método do elemento finito indicou que com núcleos metálicos fundidos foi baixa a transmissão do estresse para dente e estruturas de suporte, pois o estresse é acumulado no interior dos núcleos; com pinos de Ribbond, o estresse seria maior no dente e estruturas de suporte, sendo acumulado menos estresse no próprio núcleo. Apesar destes resultados teóricos, observou-se a fratura de sete das dez raízes com núcleos metálicos fundidos, enquanto que com núcleos de Ribbond somente duas raízes fraturaram; em sete dos núcleos de Ribbond fraturou a porção coronária do núcleo, à semelhança desta pesquisa, e em uma delas o pino deslocou.

ELLAKWA et al. ${ }^{32}$, em 2002, demonstraram que barras de resina composta indireta Solidex reforçadas com fibras de polietileno Connect impregnadas por adesivos dentinários obtiveram resistência à flexão significantemente maior que quando as fibras não foram impregnadas, indicando a importância de uma técnica adesiva correta. Observaram áreas de separação (gaps) na interface fibra-resina quando não utilizaram-se adesivos. Os melhores resultados foram obtidos utilizandose adesivos com maior carga de partículas inorgânicas; adesivos contendo etanol e 
acetona mostraram resultados inferiores. O pré-tratamento com silano diminuiu significantemente a resistência à flexão. A menor resistência à flexão foi obtida quando resina composta sem reforço foi utilizada. Como RAMOS JÚNIOR; RUNYAN; KALKAN ${ }^{95}$ já haviam observado em 1996, nos grupos reforçados os fragmentos mantiveram-se unidos entre si; no grupo sem reforço, houve falha catastrófica entre fibras e resina composta.

Assim como nos estudos de HOLLIS et al. ${ }^{52}$, em 1998, de SIRIMAI; RIIS; MORGANO ${ }^{112}$, em 1999 e de ESKITAPCIOĐLU; BELLI; KALKAN ${ }^{34}$, em 2002, no presente estudo também foram obtidos para os pinos de fibras de polietileno (grupo 1) menores valores de resistência à fratura $(45,46 \mathrm{kgf})$ que para os demais grupos experimentais, conforme demonstrado na Tabela 5.1 e na Figura 5.1, que mostraram valores em ordem crescente de 47,91kgf para o grupo 4, de 53,30kgf para o grupo 2 e de 58,67kgf para o grupo 3 . Os resultados encontrados para pinos de fibras de polietileno nesta pesquisa foram, entretanto, acima das médias observadas nos estudos acima citados. É possível que a alta deformação que as fibras de polietileno sofrem sob compressão ${ }^{14,38,45,52}$ tenha sido uma das responsáveis pela sua resistência à fratura inferior a dos pinos dentários.

Quando os valores obtidos foram submetidos à análise estatística, observou-se diferença significante entre os grupos (ANOVA), demonstrada na Tabela 5.3. A Tabela 5.4 (teste de Tukey) mostra que as diferenças são significantes somente entre os grupos 1 e 3 , ou seja, entre pinos de fibras de polietileno e pinos dentários com conduto medianamente alargado. Chama a atenção o fato de que m grupo 3 encontrou-se o maior desvio padrão, conforme demonstrado na Tabela 5.2, enquanto o desvio padrão dos demais grupos é praticamente igual.

Uma análise mais detalhada dos valores encontrados para os 15 corpos de prova do grupo 3 mostra para o corpo de prova 1 o valor mais alto do grupo e de todos os grupos $(91,05 \mathrm{kgf})$. Ao se trabalhar com dentes naturais e pinos dentários, deve-se levar em consideração as diferentes razões que podem contribuir para a variabilidade encontrada (e conseqüientemente para o desvio padrão), como: (1) grau de calcificação dos dentes; (2) pequenas variações na dimensão dos dentes e no tamanho e localização dos condutos radiculares; (3) variações na dentina causadas por diferença no conteúdo de água, condições pulpares antes da extração, idade do 
paciente e direção dos canalículos dentinários; (4) presença de microfraturas na dentina; (5) influência do preparo manual dos corpos de prova, todos fatores que, em última análise, replicam a realidade clínica ${ }^{4,50,89}$. Esta foi, inclusive, a razão que levou ao aumento do número de corpos de prova de 10 para 15 em cada grupo. Parece, porém, que embora ligeiramente diferentes do ponto de vista numérico, o comportamento experimental dos quatro grupos foi extremamente semelhante. Isto significa que, independentemente do diâmetro do conduto, se normal, medianamente ou amplamente alargado, seu preenchimento com pinos de fibras de polietileno ou pinos dentários resultará em resistência semelhante.

Estes resultados corroboraram as observações de vários autores de que fibras de polietileno flexíveis e de arquitetura entrelaçada auxiliam a distribuir a força nas estruturas às quais são incorporadas ${ }^{37,41,56,59,62,64,82,123}$, diminuindo e homogeneizando o estresse de forma a minimizar o risco de fraturas radiculares, especialmente as verticais.

KIMMEL $^{63}$, em 2000, recomendou associação entre fibras de polietileno e um pino de fibra de vidro para reforço de dentes despolpados com condutos alargados (técnica semelhante à sugerida por SIRIMAI; RIIS; MORGANO $^{112}$, em 1999, que associou o Ribbond a pinos metálicos). Este tratamento permitiria mínima remoção da dentina remanescente e produziria um pino que fornece suporte e reforço interno da raiz, possibilitando aproveitamento de raízes debilitadas. A retenção micromecânica entre as paredes internas do preparo e os demais materiais gera um monobloco adesivo estável, que deteria trincas e microfraturas existentes, prevenindo sua extensão até o periodonto.

A partir de 1993, com BOSCO; SILVEIRA; RAZABONI ${ }^{13}$ surgiram os primeiros relatos da utilização de pinos biológicos ou dentários, confeccionados a partir de dentes naturais. Estes pinos são utilizados em casos de destruição coronária extensa (parcial ou total) $11,13,24,25,46,55,94,103,129,134$ de origem cariosa ${ }^{43,46,94,103}$, traumática $^{13,25}$ ou por superinstrumentação endodôntica ${ }^{24}$ e em casos de rizogênese incompleta $^{11}$ ou distúrbios de formação e mineralização dos tecidos dentários ${ }^{55}$. Os pinos dentários estão indicados para situações de condutos excessivamente $\operatorname{alargados}^{11,12,24}$. São utilizados em dentes anteriores despolpados ${ }^{11,13,24,25,43,46,94,103,134}$, decíduos $^{43,46,55,94,103,129}$ ou permanentes ${ }^{11,13,24,25,133}$. Podem ser confeccionados a 
partir de dentes unirradiculares permanentes ${ }^{13,55,134}$ ou decíduos ${ }^{55,94,134}$, tanto normais $^{25,55,103,134}$ quanto conóides ${ }^{13}$, microdentes ${ }^{133}$ ou ainda extranumerários ${ }^{134}$. São obtidos em bancos de dentes e devidamente esterilizados ${ }^{11,13,24,25,46,94,129,134}$. Os dentes devem ser conservados em meio aquoso, pois se desidratados tornam-se friáveis e a penetração de adesivos dentinários hidrofílicos é prejudicada ${ }^{55}$.

BONILLA $^{12}$, em 2001, demonstrou que a resistência à fratura de raízes amplamente destruídas reconstruídas com pinos dentários (76,35kgf) aproxima-se daquela de dentes com preparo convencional do conduto e restaurados com núcleo metálico fundido $(87,59 \mathrm{kgf})$; além disso, sua resistência foi cerca de $30 \%$ maior do que aquela de dentes com conduto amplamente destruído e restaurados com núcleo metálico fundido $(57,64 \mathrm{kgf})$ ou reconstruídos internamente com resina composta e restaurados com núcleo metálico fundido $(53,98 \mathrm{kgf})$.

Os dentes são desgastados com pontas diamantadas sob refrigeração $0^{11,55}$, às vezes associadas a discos de carborundum ${ }^{11,24}$, até sua adaptação no interior do conduto, diretamente em boca ${ }^{11,13,25,43,94,134}$ ou em modelo de trabalho ${ }^{24,103}$. Os dentes devem ser desgastados de forma que possuam a porção que permanecerá fora do conduto recoberta por esmalte, favorecendo a retenção da resina composta $^{11,43,55,134}$. A porção do pino que permanece externamente ao conduto deveria corresponder à metade da altura da coroa dentária ${ }^{43,46}$.

A cimentação pode ser executada com ionômero de vidro $^{13,25,43,55,128,129}$ ou cimentos resinosos duais ${ }^{11,24,103,129,134}$. Ranhuras nos pinos aumentam seu embricamento mecânico com o material cimentante ${ }^{55}$. A coroa dentária pode ser restaurada com resina composta fotopolimerizável, sendo que a quantidade de resina necessária é minimizada ${ }^{24,25,46,55,128,134}$, com a utilização de fragmentos de dentes naturais ${ }^{55}$ ou com coroas de dentes naturais ${ }^{43,94}$. Também é possível confeccionar um núcleo de preenchimento com resina composta para posterior restauração com uma coroa total ${ }^{11,103}$.

Segundo a literatura, o pino dentário oferece vantagens como: (1) maior retenção para a resina composta que os demais tipos de pino, pois pode ser submetido ao condicionamento ácido ${ }^{11,13,24,25,134}$; (2) técnica conservadora (não necessita desgaste adicional para retenção); (3) adaptação à configuração do conduto alargado, favorecendo a resistência dentária ${ }^{11}$; (4) ótimo acabamento e polimento ${ }^{128}$; 
(5) menor tempo clínico que técnicas com materiais restauradores diretos ${ }^{43,55}$; (6) gera menor concentração de estresse que pinos metálicos, pois possui resiliência similar à da estrutura dentária (equilíbrio de um dente normal) ${ }^{11,134}$; (7) translucidez (ótima estética) $^{11,24} ;(8)$ extremamente econômico ${ }^{24,55,128}$; (9) pode-se dispensar a fase laboratorial (sessão única) ${ }^{11,43,134}$.

Vários autores ${ }^{24,55,71,87,91}$ ressaltaram que a restauração biológica é uma excelente alternativa, pois nenhum material restaurador supera as propriedades mecânicas e estéticas da estrutura dental.

Suas desvantagens seriam: (1) necessidade de um banco de dentes ${ }^{43,55}$; (2) relativa dificuldade para adaptação ao preparo ${ }^{12,43,55}$; (3) recusa de alguns pacientes $^{21,43}$. O fato de que não existem ainda dispositivos apropriados para confecção de pinos dentários é talvez sua maior desvantagem, pois é necessário um certo tempo para confeccioná-los artesanalmente e adaptá-los ao conduto; este tempo, porém, diminui com a prática. Contudo, é provável que fresadoras apropriadas ou técnicas de CAD-CAM venham brevemente preencher esta lacuna ${ }^{87}$. Alguns autores contra-indicam a técnica para pacientes com higiene inadequada, devido ao risco de cárie do pino ${ }^{87,134}$.

Nos espécimes dos grupos 2, 3 e 4 foram utilizados pinos dentários. No grupo 2, procedeu-se a preparo convencional do conduto; no grupo 3, a um alargamento mediano; e no grupo 3, a um alargamento amplo deste conduto. Da mesma forma que BONILLA ${ }^{12}$, em 2001, obturourse o conduto do pino biológico com cimento resinoso, utilizando brocas lentulo. O conduto do pino pode também ser preenchido com ionômero de vidro convencional ${ }^{134}$ ou modificado por resina ${ }^{94}$, ou ainda com resina composta ${ }^{24}$.

Da mesma forma que para os pinos de fibras de polietileno, os resultados de resistência à fratura dos grupos reforçados com pinos dentários parecem indicar que os mesmos deveriam ser utilizados somente em elementos dentários ainda possuidores de algum remanescente coronário, para que seja possível obtenção de efeito férula. A altura mínima de remanescente proposta em diferentes estudos para obtenção da férula é variável: $1 \mathrm{~mm}^{83,97,115} ; 1,5 \mathrm{~mm}^{70}$ ou $2 \mathrm{~mm}^{4,10}$. MORGANO; BRACKETT ${ }^{86}$, em 1999 e RAYGOT; CHAI; JAMESON ${ }^{97}$, em 2001, afirmaram que a resistência de dentes endodonticamente tratados com mínima 
quantidade de estrutura dentária coronária depende principalmente das propriedades mecânicas do material do núcleo e de seu desenho.

Sobretudo enquanto não forem executadas mais pesquisas confirmando que os pinos biológicos e de fibras de polietileno são clinicamente seguros, poder-se-ia ponderar em evitar indicá-los para situações de risco aumentado, tais como: 1) bruxismo; 2) pilares de prótese parcial removível com extensão distal; 3) pilares de prótese parcial fixa com espaço edêntulo longo ou com elementos em cantilever; 4) situações de oclusão desfavorável, como trespasse vertical acentuado. Recomenda-se ainda cautela no caso de condutos muito amplos, como os do grupo 4 (espessura de parede radicular ao nível do terço cervical de somente 0,5mm); este grupo obteve os menores valores de resistência à fratura entre os três grupos reforçados com pinos dentários $(47,91 \mathrm{kgf})$, conforme se observa na Tabela 5.1. Uma taxa de sobrevivência mais baixa é esperada nas circunstâncias acima descritas.

Entretanto, é muito importante observar que o valor de resistência à fratura obtido no grupo 4 (47,91kgf), ou seja, dentes totalmente debilitados pelo amplo alargamento do conduto, foi quase idêntico àquele obtido no grupo 1 (45,46kgf) (Tabela 5.1), onde o alargamento do conduto era mínimo (somente $1,1 \mathrm{~mm})$ e que, do ponto de vista estatístico, os três grupos de pinos dentários apresentaram o mesmo comportamento, como já comentado. Pode-se inferir que o pino dentário realmente possui capacidade de reforçar dentes fragilizados por alargamento excessivo do conduto, favorecendo seu prognóstico a longo prazo, conforme a literatura sugere ${ }^{11,12,24,134}$; isto provavelmente ocorre graças ao módulo de elasticidade semelhante entre pino dentário e raiz e devido à íntima adesão entre pino e estrutura dentária. É recomendável que o material usado para núcleos de preenchimento possua módulo de elasticidade similar ao da dentina ${ }^{30,40,58,100,106}$. Por outro lado, a capacidade dos pinos de fibras de polietileno em reforçar dentes despolpados parece inferior àquela dos pinos dentários, se considerarmos os resultados acima descritos.

Com relação ao tipo de fratura, como demonstrado na Tabela 5.5 e na Figura 5.2, observa-se que apenas duas raízes dos 15 corpos de prova do grupo 1 (com pinos de fibras de polietileno) sofreram fraturas, que por serem no terço cervical não invibializariam o reaproveitamento do dente. Nos grupos 2, 3 e 4, 
fraturas radiculares ocorreram, respectivamente, em 8, 7 e 15 corpos de prova, com porcentagens de 53,2\%, 46,6\% e 100\%. Parece óbvio se aceitar que, embora não se conseguisse distinguir numericamente os condutos com preparo convencional (grupo 2) dos medianamente alargados (grupo 3), as raízes com menor espessura do remanescente (grupo 4), que foram amplamente alargadas, mostraram-se mais frágeis e mais susceptíveis a fraturas.

A semelhança no padrão de fratura entre o grupo 2 e o grupo 3 provavelmente deveu-se ao fato de que no grupo 3 tanto o pino quanto a dentina remanescente eram consideravelmente espessos. Por outro lado, no grupo 1 a resina da porção coronária do núcleo fraturava na grande maioria das vezes antes da estrutura dentária, possivelmente devido ao dobramento das fibras de polietileno, que possuem baixa resistência à compressão $0^{14,38,41}$; este pode ter sido um dos fatores que impediu o grupo 1 de atingir maiores valores de resistência à fratura.

Também observou-se que o grupo 3 obteve numericamente maior valor de resistência à fratura que o grupo 2 (embora estatisticamente similar), mesmo que no grupo 2 houvesse maior volume de dentina remanescente que no grupo 3. A razão disto pode ter sido a mesma que gerou padrões de fraturas semelhantes entre estes grupos, ou seja, o fato de que no grupo 2 o pino dentário era mais delgado (menos de 1,1 mm), fraturando mais facilmente (usualmente ao nível cervical), muitas vezes com menores valores que no grupo 3. Já no grupo 3, havia um melhor equilíbrio entre a espessura do pino e da dentina remanescente, ou seja, ambos eram relativamente espessos, fraturando geralmente com valores maiores.

No grupo 2 (pino dentário com preparo convencional do conduto) e no grupo 3 (pino dentário com conduto medianamente alargado), o tipo e a porcentagem de fraturas radiculares foram similares (somando-se falhas radiculares no terço cervical e médio), bem como foi semelhante a quantidade de fraturas da porção coronária do núcleo e/ou do pino (Tabela 5.5). Em ambos os grupos houve, em 14 das 15 amostras, falha ou na porção coronária do núcleo ou no terço cervical da raiz (tipo e porcentagem de falhas favoráveis à manutenção do remanescente dentário), o que pode ser considerado como um fator posistivo.

No grupo 4 (pino dentário com conduto amplamente alargado) ocorreu o maior número de fraturas radiculares ao nível do terço médio (cinco de 15 
amostras), sendo que as outras dez amostras fraturaram ao nível do terço cervical (Tabela 5.5). Houve $100 \%$ de fraturas radiculares, assim como na pesquisa de TJAN; $\mathrm{WHANG}^{124}$, em 1985, onde os condutos de um dos grupos experimentais foram preparados de forma que a espessura da parede vestibular da raiz fosse de $1 \mathrm{~mm}$. No estudo de SOARES ${ }^{113}$, em 1999, onde um dos grupos possuía 0,5mm de espessura das paredes radiculares no terço cervical e na pesquisa de BONILLA ${ }^{12}$, em 2001, que utilizou para o grupo de pinos dentários um preparo afunilado similar ao do presente estudo, todas as raízes fraturaram, da mesma forma. Levando-se em consideração a espessura mínima das paredes radiculares ao nível do terço cervical $(0,5 \mathrm{~mm})$ e o número de fraturas ocorridas no terço cervical da raiz, o resultado ainda pode ser considerado surpreendentemente favorável.

Nas Figuras 6.1, 6.2 e 6.3 podem ser observados alguns dos tipos de fraturas mais comuns ocorridos neste estudo.

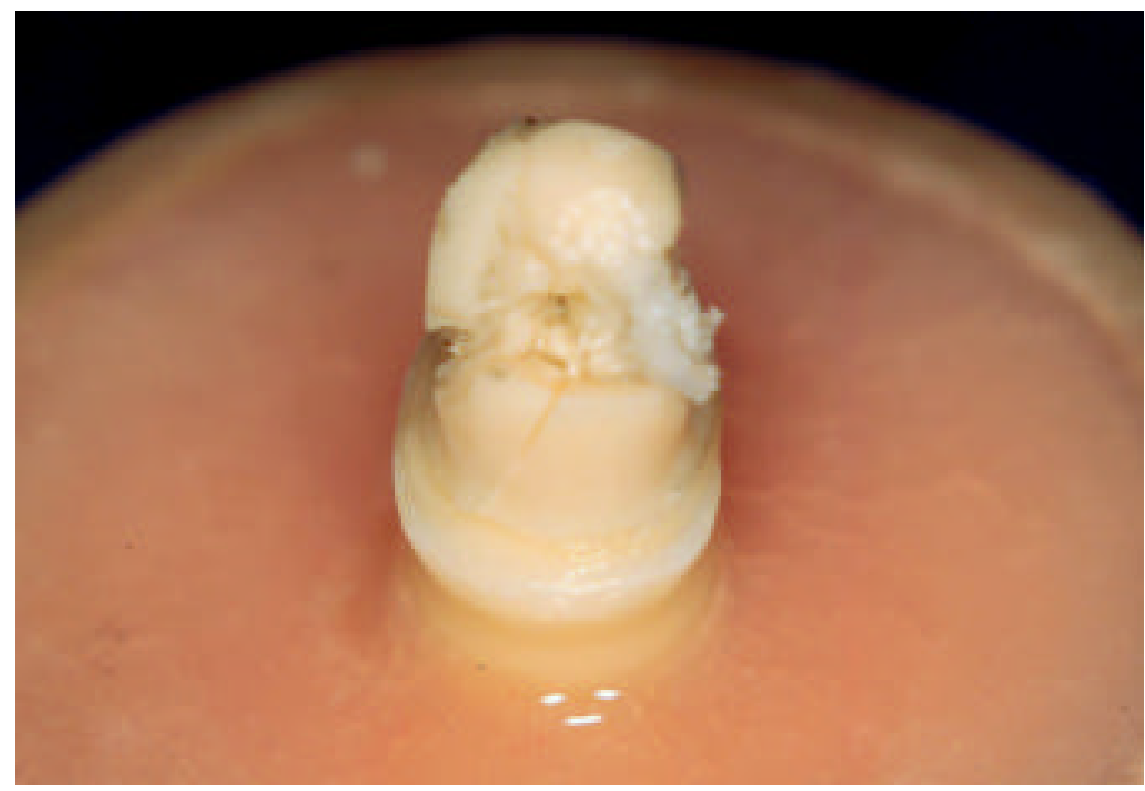

FIGURA 6.1 - Fratura da porção coronária em corpo de prova do grupo 1 (pino de fibras de polietileno com preparo convencional do conduto) 


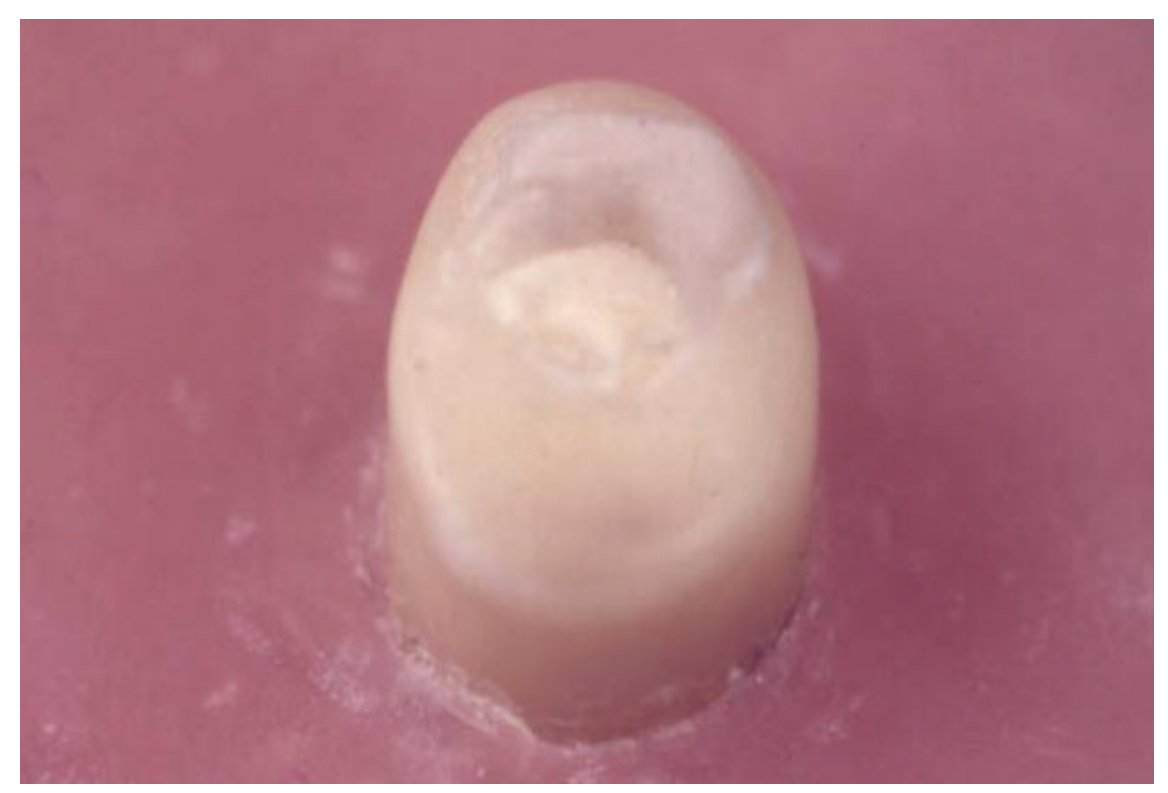

FIGURA 6.2 - Fratura ao nível do terço cervical do pino em corpo de prova do grupo 2 (pino dentário com preparo convencional do conduto)

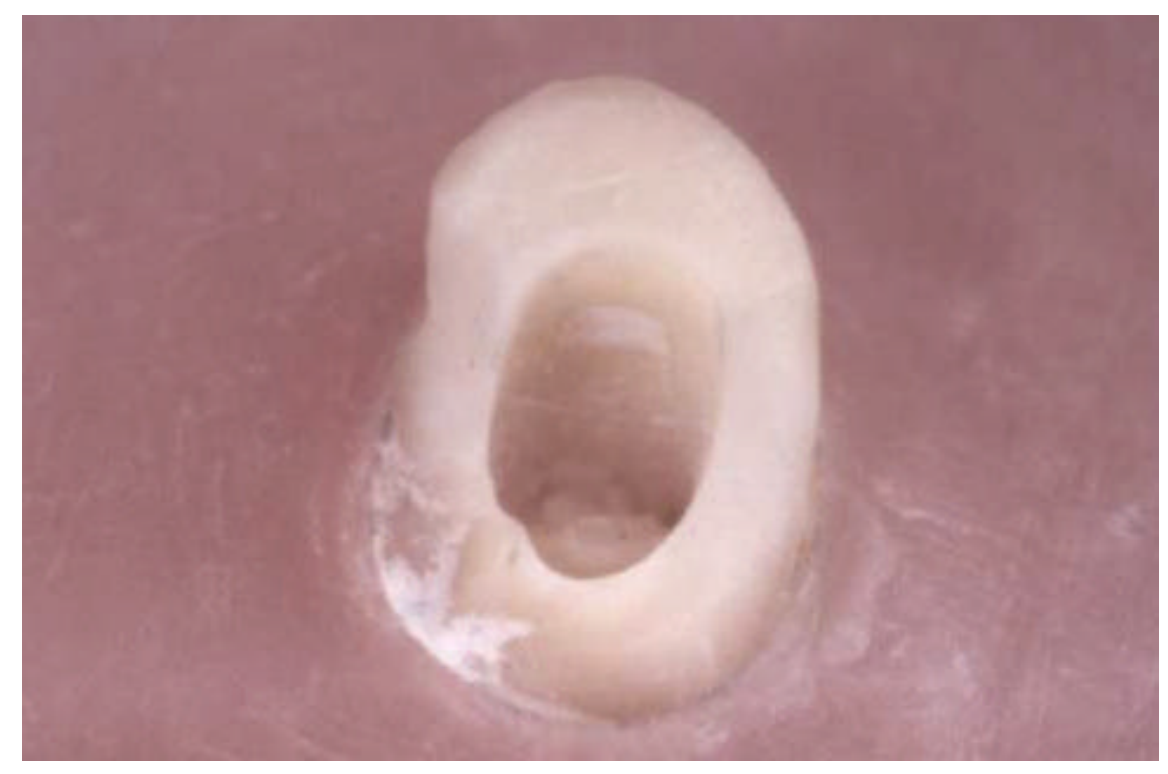

FIGURA 6.3 - Fratura radicular ao nível do terço cervical em corpo de prova do grupo 3 (pino dentário com conduto mediamente alargado) 


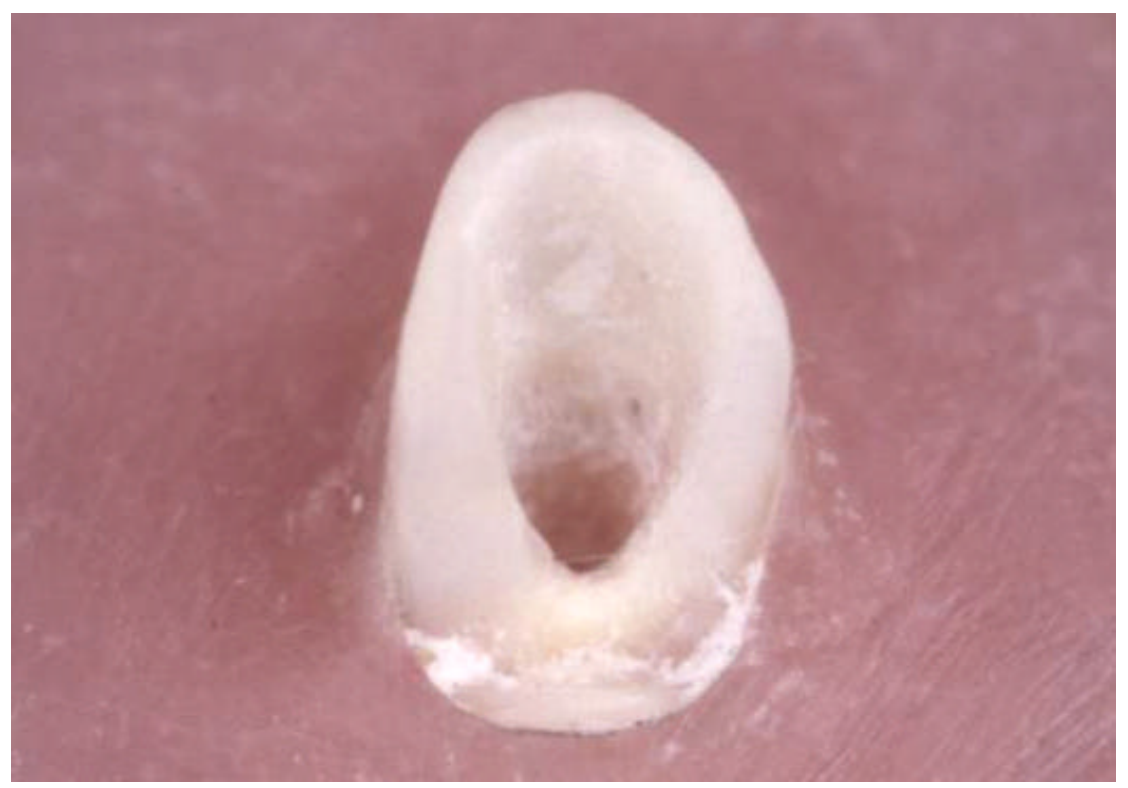

FIGURA 6.4 - Fratura radicular ao nível do terço cervical em corpo de prova do grupo 4 (pino dentário com conduto amplamente alargado)

O mérito maior dos pinos de fibras de polietileno está em seu padrão de falha, que permite a recuperação do elemento dentário em quase todos os casos; isto pode tornar sua utilização viável, especialmente naqueles casos onde ainda houver remanescente coronário. Apesar deste modo de fratura favorável, este tipo de pino deve ser melhor pesquisado, antes que venha a ser indicado para uso rotineiro na clínica diária, principalmente em casos de raízes enfraquecidas ou em dentes com pouco ou nenhum remanescente coronário. Seriam especialmente importantes estudos adicionais deste material como reforço para condutos medianamente ou amplamente alargados, a fim de evidenciar valores de resistência à fratura e tipos de falha do mesmo nestas situações.

Já em 1990, KING; SETCHELL ${ }^{65}$ haviam demonstrado que pinos de fibras de carbono (que possuem propriedades próximas às da estrutura dentária, como os pinos utilizados na presente pesquisa) possuíam desempenho comparável ou melhor que o dos pinos pré-fabricados metálicos, além de modo de falha (nível de fratura) mais favorável para o remanescente dentário que aquele dos pinos metálicos. Adequada resistência à fratura e descimentação, bem como o mesmo modo de falha 
já descrito continuaram a ser obtidos em pesquisas posteriores com pinos de fibras de carbono, tanto in vitro $28,58,77,80,97,106$ quanto clinicamente ${ }^{39,44,77}$. SIDOLI; KING; SETCHELL ${ }^{106}$, em 1997, observaram que, embora em seu estudo a resistência destes pinos tenha sido inferior àquela dos núcleos metálicos fundidos ou dos pinos metálicos pré-fabricados, as cargas de falha excederam aquelas que normalmente ocorrem clinicamente, além de que a possibilidade de manutenção da raiz após fratura deve sempre ser levada em conta na seleção do pino. PURTON; LOVE ${ }^{92}$, em 1996, evidenciaram que em condutos estreitos (cerca de 1mm) pinos de aço inoxidável serrilhados possuíam maior retenção e rigidez que pinos de fibras de carbono. BURGESS; DOUGLAS; NORLING ${ }^{18}$, em 1997 observaram que tais pinos foram significantemente mais fracos em relação à cargas de flexão, tração e compressão que pinos metálicos pré-fabricados. Já no estudo de RAYGOT; CHAI; JAMESON $^{97}$, em 2001, não houve diferenças significantes na resistência à fratura ou no modo de falha entre núcleos metálicos fundidos, pinos de aço inoxidável e pinos de fibras de carbono; estes últimos, no entanto, demonstraram entre 70 a $80 \%$ de fraturas favoráveis.

Em 2002, AKKAYAN; GÜLMEZ ${ }^{3}$ demostraram que também pinos de fibras de quartzo e de fibras de vidro exibiram adequados valores de resistência à fratura, além de, na grande maioria das situações, fraturas passíveis de reparo (provavelmente devido ao módulo de elasticidade similar ao da dentina). Nenhuma fratura nos terços médio ou apical foi encontrada com pinos de fibras de quartzo.

Os resultados demonstrados com a utilização de pinos dentários também foram promissores, tanto em relação ao padrão de falhas quanto em relação aos valores de resistência à fratura, que foram maiores que aqueles dos pinos de fibras de polietileno, inclusive em situações de risco como condutos medianamente e amplamente alargados. Desta forma, indicam-se pesquisas de acompanhamento clínico a longo prazo de pinos dentários e, obtendo-se resultados favoráveis, será possível reciclar órgãos dentários que tenham sido removidos por razões diversas, pois, como a literatura afirma, não existe material restaurador cujas propriedades superem as do próprio elemento dentário $24,55,71,87,91$.

Encontram-se escassos estudos de acompanhamento clínico dos pinos de fibras de polietileno. HORNBROOK; HASTINGS ${ }^{54}$, em 1995, utilizaram a 
técnica em 24 casos clínicos durante 12 meses, sem nenhuma falha, mesmo em dentes severamente comprometidos. KARNA ${ }^{62}$, em 1996, reconstruiu cerca de 130 dentes com núcleos de Ribbond, observando somente dois casos de fratura de raiz (que possuíam paredes radiculares com menos de $1 \mathrm{~mm}$ de espessura) e três casos de fratura da resina composta da porção coronária (falha comum destes núcleos, inclusive no presente estudo). ÍÑIGUEZ ${ }^{56}$, em 2000, utilizou a técnica em cerca de 500 casos, com uma quantidade mínima de fracassos, atribuídos a erros na técnica de adesão.

Embora muitas vezes os casos clínicos com pinos de fibras de polietileno descritos na literatura envolvam reconstruções de elementos dentários com pouco ou nenhum remanescente coronário ${ }^{59,63,90,107}$, os resultados de resistência à fratura obtidos nesta pesquisa (Tabela 5.1 e Figura 5.1) sugerem que tal técnica deveria ser utilizada somente em elementos dentários com alguma quantidade de remanescente coronário, cujo valor crítico provavelmente varia entre 1 a $2 \mathrm{~mm}$ de estrutura dental coronária sadia $4,10,70,97,115$, visando um efeito férula. De acordo com IÑIGUEZ ${ }^{56}$, em 2000, pinos de fibra de polietileno são especialmente indicados para dentes despolpados com 50\% de estrutura dentária remanescente em dentes anteriores ou $30 \%$ em dentes posteriores; quando possível, deve-se manter uma altura de remanescente dentário de pelo menos $2 \mathrm{~mm}$ de altura.

Embora seja difícil, como em muitos estudos laboratoriais, extrapolar os resultados diretamente para situações clínicas, é provável que, ao reabilitar elementos dentários com raízes medianamente ou amplamente destruídas, os pinos dentários virão melhorar seu prognóstico a longo prazo, evitando sua extração precoce e possibilitando que sejam capazes de reter um núcleo e suportar uma restauração funcional e estética.

Ainda como vantagem dos pinos dentários e de fibras de polietileno, deve-se observar o fato de que sua estética é superior àquela dos núcleos metálicos, especialmente se utilizados em raízes debilitadas e com paredes finas. Pinos metálicos alteram a transmissão de luz através da estrutura dentária ${ }^{121}$; se utilizados pinos de metais não-preciosos, produtos de corrosão podem descolorir a raiz e predispor à fratura da mesma ${ }^{120}$. 
A restauração de dentes endodonticamente tratados, mais susceptíveis à fratura devido principalmente à perda de estrutra dental, ainda pode ser considerada um desafio, suscitando muitas controvérsias e dúvidas. Não existe uma opinião única sobre a forma ideal de recuperar dentes nestas condições, especialmente quando as raízes estão muito debilitadas. Muitas vezes não há base científica para auxiliar a determinar a indicação mais correta de determinada técnica ou do pino mais adequado para a situação. A restauração ideal deveria permitir a recuperação tanto da função quanto da estética, fornecendo ainda um prognóstico favorável e seguro a longo prazo. Além disso, o procedimento empregado deve ser o mais conservador possível, uma vez que nenhum material restaurador substitui o tecido dental com a mesma eficiência, de forma que este deve ser poupado tanto quanto possível.

É preciso buscar constantemente novas alternativas para a restauração e, se possível, reforço de dentes tratados endodonticamente. De acordo com os resultados obtidos neste estudo, os pinos dentários parecem ideais para reforço de raízes debilitadas, provavelmente devido às suas propriedades físico-mecânicas similares à estrutura dentária e à sua capacidade de adesão com a mesma e com os materiais restauradores; além disso, permitem a reciclagem de um material tão nobre quanto o elemento dentário. Pesquisas futuras deveriam procurar formas de facilitar e padronizar a confecção dos pinos dentários. Embora tenham sido observados menores valores de resistência à fratura para pinos de fibras de polietileno que para pinos dentários, é inegável que o tipo de fratura associado a este material pode ser considerado muito favorável no que se refere à possibilidade de conservação da raiz, sugerindo que sejam executados estudos adicionais com fibras de polietileno. Estas pesquisas poderiam buscar, da mesma forma que para os pinos dentários, uma forma mais padronizada para a obtenção destes pinos, possivelmente buscando transformálas em pinos pré-fabricados, tal como os pinos de fibras de vidro ou fibras de carbono, aprimorando e homogeneizando, desta forma, as suas propriedades, e assim permitindo que sejam alcançados melhores resultados. 


\section{CONCLUSÕES}

Buscando-se elucidar a proposição inicial através da metodologia estabelecida e após a aplicação da análise estatística aos valores obtidos neste estudo, pode-se concluir que:

7.1. De forma geral, a resistência à fratura sob carga compressiva mostrou similaridade entre os grupos reconstruídos com pinos dentários em relação àqueles com fibras de polietileno, sendo que o enfraquecimento radicular pôde ser otimizado com os pinos dentários.

7.2. Houve diferença estatisticamente significante somente entre o Grupo 1 e o Grupo 3, sendo que os demais grupos não apresentaram diferenças estatisticamente significantes quando comparados entre si.

7.3. A reconstrução com pinos de fibras de polietileno demonstrou ampla predominância de fratura do pino e/ou da porção coronária do núcleo.

7.4. Os dentes reconstruídos com pinos dentários apresentaram fraturas com padrões variados, que envolveram principalmente a porção cervical da raiz, bem como a fratura do pino e/ou da porção coronária do núcleo; em condutos amplamente alargados os pinos dentários estabeleceram essencialmente fraturas radiculares. 


\section{REFERÊNCIAS BIBLIOGRÁFICAS}

1 ABREU, M. G.; FIUZA-GONÇALVES, I. M.; OLIVEIRA, V. J. Colagem heterógena em odontopediatria: revisão de literatura e apresentação de caso clínico. J. bras. Odontopediat. Odont. Bebê, v. 5, n. 24, p. 147-53, mar./abr. 2002.

2 ALBUQUERQUE, R. C. Pinos intra-radiculares pré-fabricados. In: CARDOSO, R. J. A.; GONÇALVES, E. A. N., coord. Oclusão/ATM, prótese sobre implantes e prótese bucomaxilofacial. São Paulo, Artes Médicas, 2002. Cap. 19, p. 441-62.

3 AKKAYAN, B.; GÜLMEZ, T. Resistance to fracture of endodontically treated teeth restored with different post systems. J. prosth. Dent., v. 87, n. 4, p. 431-7, Apr. 2002.

4 ASSIF, D. et al. Effect of post design on resistance to fracture of endodontically treated teeth with complete crowns. J. prosth. Dent., v. 69, n.1, p. 36-40, Jan. 1993.

5 BARABAN, D. J. The restoration of pulpless teeth. Dent. Clin. N. Amer., p. 633-53, Nov. 1967.

6 BARABAN, D. J. A simplified method for making post and cores. J. prosth. Dent., v. 24, n. 3, p. 287-97, Sept. 1970.

7 BARABAN, D. J. Immediate restoration of pulpless teeth. J. prosth. Dent., v. 28 , n. 6 , p. 607-12, Dec. 1972.

8 BARATIERI, L. N.; MONTEIRO JÚNIOR., S.; ANDRADA, M. A. C. The "sandwich" technique as a base for reattachment of dental fragments. Quintessence Int., v. 22, n. 2, p. 81-5, Feb. 1991.

\footnotetext{
* Normas recomendadas para uso no âmbito da Universidade de São Paulo, com base no documento "Referências bibliográficas: exemplo", emanado do Conselho Supervisor do Sistema Integrado de Bibliotecas da USP, em reunião de 20 de setembro de 1990.
} 
BARATIERI, L. N. et al. Reattachment of a tooth fragment with a "new" adhesive system: a case report. Quintessence Int., v. 25, n. 2, p. 91-6, Feb. 1994.

10 BARKHORDAR, R. A.; RADKE, R.; ABBASI, J. Effect of metal collars on resistance of endodontically treated teeth to root fracture. J. prosth. Dent., v. 61, n. 6, p. 676-8, June 1989.

11 BATISTA, A.; LOPES, C. G. A utilização de pino dentinário para reforço coronoradicular em dentes com rizogênese incompleta tratados endodonticamente. Rev. bras. Prót. Clín. Lab., v. 1, n. 3, p. 199-21, maio/jun. 1999.

12 BONILLA, M. E. G. Avaliação da resistência à fratura transversal de raízes amplamente destruídas reconstruídas com núcleos. Bauru, 2001. 110 p. Dissertação (Mestrado) - Faculdade de Odontologia de Bauru, Universidade de São Paulo.

13 BOSCO, A. R.; SILVEIRA, G. P.; RAZABONI, A. M. Uso de dentes naturais com finalidade de substituir núcleos fundidos: apresentação de caso clínico. In: JORNADA ODONTOLÓGICA DE RIBEIRÃO PRETO, 15., Ribeirão Preto, 1993. Anais. Ribeirão Preto, Ed. FORP, 1993. p. 27.

14 BOTTINO, M. A. et al. Materiais poliméricos. In: . Estética em reabilitação oral metal free. São Paulo, Artes Médicas, 2001. Cap. 6, p. 348-79.

15 BOWEN, R. L. Adhesive bond ing of various materials to hard tooth tissues solubility of dentinal smear layer in dilute acid buffers. Int. dent. J., v. 28, n. 2, p. 97-107, June 1978.

16 BRADEN, M.; LADIZESKY, N. H. Denture base poly (methyl metacrilate) reinforced with ultra-high modulus polyethylene fibers. Brit. dent. J., v. 164, n. 3, p. 109-13, Feb. 1988.

17 BUONOCORE, M. G. A simple method of increasing the adhesion of acrylic filling materials to enamel surfaces. J. dent. Res., v. 34, n. 6, p. 849-53, Dec. 1955. 
18 BURGESS, J. O.; DOUGLAS, A. S.; NORLING, B. K. Post retention in root filled teeth. J. dent. Res., v. 76, n. 1, p. 183, Jan. 1997. /Abstract n. $1357 /$

19 BUSATO, A. L.; ANTUNES, M. Colagem heterógena em dentes anteriores fraturados. Rev. gaúcha Odont., v. 32, n. 2, p. 137-40, abr./jun. 1984.

20 BUSATO, A. L. et al. Colagem de fragmentos dentários. Rev. gaúcha Odont., v. 33, n. 4, p. 326-8, out./dez. 1985.

21 BUSATO, A. L. et al. Biological restorations using tooth fragments. Amer. J. dent., v. 11, n. 1, p. 46-9, Feb. 1998.

22 BUTZ, F. et al. Survival rate and fracture strength of endodontically treated maxillary incisors with moderate defects restored with different post-andcore systems: an in vitro study. J. prosth. Dent., v. 14, n. 1, p. 58-64, Jan./Feb. 2001.

23 CAPUTO, A. A.; STANDLE, J. P. Pins and posts - why, when, how. Dent. Clin. N. Amer., v. 20, n. 2, p. 299-12, Apr. 1976.

24 CÂNDIDO, M. S.; POZZOBON, R. T.; PORTO NETO, S. T. Recuperação estética através de colagem heterógena corono-radicular, faceta e recontorno. J. bras. Odont. Clín., v. 3, n. 15 p. 29-33, out. 1999.

25 CENTOLA, A. L. B. Soluções alternativas para restauração da estética apresentação de casos clínicos. Âmbito Odont., v. 6, n. 3, p. 19-24, set./out. 1996.

26 CHOW, T. W.; CHENG, Y. Y.; LADIZESKY, N. H. Polyethylene fiber reinforcerd poly(methylmetacrylate) - water sorption and dimensional changes during immersion. J. dent., v. 21, n. 6, p. 367-72, Dec. 1993.

27 CHOW, T.W; LADIZESKY, N. H.; CLARKE, D. A. Acrylic resins reinforced with woven highly drawn linear polyethylene fibers. 2. Water sorption and clinical trials. Aust. dent. J., v. 37, n. 6, p. 433-8, Dec. 1992.

28 DEAN, J. P., JEANSONNE, B. G., SARKAR, N. In vitro evaluation of a carbon fiber post. J. Endod., v. 24, n. 12, p. 807-10, Dec. 1998.

DIETSCHI, D.; ROMELLI, M.; GORETTI, A. Adaptation of adhesive posts and cores to dentin after fatigue testing. Int. J. Prosthodont., v. 10, n. 6, p. 498-507, Nov./Dec. 1997. 
30 DURET, B.; DURET, F.; REYNAUD, M. Long-life physical property preservation and postendodontic rehabilitation with the Composipost. Comp. Continuing Educ. Dent., v. 17, p. 565-73, 1996. Supplement 20.

31 DURET, P. B., REYNAUD, M., DURET, F. Un nouveau concept de reconstrution corono-radiculaire: le composiposte (I). Chir. dent. Fr., v. 60, n.54, p. 131-41, Nov. 1990 apud MANNOCCI, F. et al. ${ }^{77}$. p. 12-17.

32 ELLAKWA, A. E. et al. Influence of bonding agent composition on flexural properties of an ultra-high molecular weight polyethylene fiber-reinforced composite. Oper. Dent., v. 27, n. 2, p. 184-91, Mar./Apr. 2002.

33 ESBERARD, R. M.; SILVA FILHO, F. P. M.; GABRIELLI, F. Fratura coronária em dente anterior. Rev. Ass. paul. cirurg. Dent., v. 32, n. 2, p. 130-4, mar./abr. 1978.

34 ESKITAßIOĐLU, G.; BELLI, S.; KALKAN, M. Evaluation of two post core systems using two different methods (fracture strength test and a finite elemental stress analysis). J. Endod., v. 28, n. 9, p. 629-33, Sept. 2002.

35 FABRICATING a fiber-reinforced post \& core using GlasSpan ceramic fibers by GlasSpan, Inc. Dent. prod. rep., v. 31, n. 1, p. 22-3, Apr. 1997.

36 FAUCHARD, P. Le chirurgien dentisté; ou, traité des dents. Paris, Jean Mariette, 1728 apud RING, M. E. ${ }^{98}$.

37 FELIPPE, L. A. et al. Fibras de reforço para uso odontológico - fundamentos básicos e aplicações clínicas. Rev. Ass. paul. cirurg. Dent., v. 55, n. 4, p. 245-50, jul./ago. 2001.

38 FIBER-REINFORCED composites. Dent. Adv., v. 15, n. 2, p. 1-5, Mar. 1998.

39 FREDRIKSSON, $M$ et al. A retrospective study of 236 patients with teeth restored by carbon fiber- reinforced epoxy resin posts. J. prosth. Dent., v. 80, n. 2, p. 151-7, Aug. 1998.

40 FREEDMAN, G. The carbon fiber post: metal-free, post-endodontic reabilitation. Oral Health, v. 86, n. 2, p. 23-30, Feb. 1996.

41 FREILICH, M. A. et al. Fiber-reinforced composites in clinical dentistry. Chicago, Quintessence, 2000. 
42 GABRIELLI, F. et al. Apresentação e avaliação clínica de uma técnica de restauração de dentes anteriores com fragmentos adaptados de dentes extraídos. Rev. gaúcha Odont., v. 29, n. 2, p. 83-7, abr./jun. 1981.

43 GALINDO, V. A. C. et al. Pinos biológicos e colagens de coroas naturais uma alternativa na reabilitação de dentes decíduos anteriores. J. bras. Odontopediat. Odont. Bebê, v. 3, n. 16, p. 513-9, nov./dez. 2000.

44 GLAZER, B. Restoration of endodontically treated teeth with carbon fiber posts - a prospective study. J. Canad. dent. Ass., v. 66, n. 11, p. 613-8, Dec. 2000.

45 GOLDBERG, A. J. et al. Flexure properties and fiber architecture of commercial fiber reinforced composites. J. dent. Res., v. 77, n. 2, p. 226, Mar. 1998. /Abstract n. 967/

46 GUEDES, C. C. Pinos intra-radiculares utilizados para o tratamento de grandes destruições em dentes decíduos anteriores. Disponível na Internet. http://www.dominiobucal.com.br/pedi2.htm. 09 Jul. 2002.

47 GUTTERIDGE, D. L. The effect of including ultra-high-modulus polyethylene fiber on the impact strength of acrylic resin. Brit. dent. J., v. 164, n. 6, p. 177-80, Mar. 1988.

48 GUZY, G. E.; NICHOLLS, J. I. In vitro comparison of intact endodontically treated teeth with and without endo-post reinforcement. J. prosth. Dent., v. 42, n. 1, p. 39-42, July 1979.

49 HEYDECKE, G.; PETERS, M. C. The restoration of endodontically treated, single-rooted teeth with cast or direct post and cores: a sistematic review. J. prosth. Dent., v. 87, n. 4, p. 380-6, Apr. 2002.

50 HEYDECKE, G. et al. Fracture strenght after dynamic loading of endodontically treated teeth restored with different post-and-core systems. J. prosth. Dent., v. 87, n. 4, p. 438-45, Apr. 2002.

$51 \mathrm{HO}, \mathrm{M}-\mathrm{H}$. et al. Three-dimensional finite element analysis of the effects of post on stress distribuition in dentin. J. prosth. Dent., v. 72, n. 4, p. 36772, Oct. 1994.

52 HOLLIS, R. A. et al. Post and core, state-of-art. Clin. Res. Ass., v. 22, n. 1, p. 2-3, Nov. 1998. 
53 HOLMES, D. C.; DIAZ-ARNOLD, A. M.; LEARY, J. M. Influence of post dimension on stress distribution in dentin. J. prosth. Dent., v. 76, n. 2, p. 140-7, Feb. 1996.

54 HORNBROOK, D. S.; HASTINGS, J. H. Use of bondable reinforcement fiber for post and core build-up in endodontically treated tooth: maximizing strength and aesthetics. Pract. Periodont. Aesth. Dent., v. 7, p. 33-42, May 1995.

55 IMPARATO, J. C. P. Restaurações biológicas em dentes decíduos. Colagem de fragmentos de dentes naturais. In: CORREA, M. S. N. P. Odontopediatria na primeira infância. São Paulo, Ed. Santos, 1998. Cap. 33, p. 463-72.

56 ÍÑIGUEZ, I. Odontología restaurativa directa. Usos de RIBBOND para restaurar dientes tratados endodónticamente. Rev. Ass. dent. mexic. v. 57, n. 2, p. 54-8, mar./abr. 2000.

57 ISAIA, A. M. B. et al. Colagem heterógena em dentes posteriores. Rev. gaúcha Odont., v. 44, n. 5, p. 227-9, set./out. 1996.

58 ISIDOR, F, ODMAN, P, BRONDUM, K. Intermittent loading of teeth restored using prefabricated carbon fiber posts. Int. J. Prosthodont., v. 9, n. 2, p. 131-6, Mar./Apr. 1996.

59 KAKAR, M. Post and core fabrication with resin based materials and reinforcing fibers. Disponível na Internet: http://www.bitein.com/dcp03.htm. 11 Nov. 2001.

60 KAKEHASHI, Y. et al. A new all-ceramic post and core system: clinical, technical, and in vitro results. Int. J. Periodont. Restorat. Dent., v. 18, n. 6, p. 587-93, Dec. 1998.

61 KANKA III, J. Replacement of a fractured incisor fragment over pulpal exposure: a case report. Quintessence Int., v. 24, n. 2, p. 81 84, Feb. 1993.

62 KARNA, J. C. A fiber composite laminate endodontic post and core. Amer. J. Dent., v. 9, n. 5, p. 230-2, Oct. 1996. 
63 KIMMEL, S. S. Restoration and reinforcement of endodontically treated with a polyethylene ribbon and prefabricated fiberglass post. Gen. Dent., v. 48, n. 6, p. 700-6, Nov./Dec. 2000.

64 KIMMEL, S. S. Restoration of endodontically treated tooth containg wide or flared canal. N. Y. St. dent. J., v. 66, n. 10, p. 36-40, Dec. 2000.

65 KING, P. A.; SETCHELL, D. J. An in vitro evaluation of a prototype CFRC prefabricated post developed for the restoration of pulpless teeth. J. oral Rehab., v. 17, n. 6, p. 599-609, Nov. 1990.

66 KONZEN, V.; BUSATO, A. L. S. Coroa total com dente natural. Rev. gaúcha Odont., v. 38, n. 3, p. 195-7, maio/jun. 1990.

67 LADIZESKY; N. H.; CHOW, T. W. The effect of interface adhesion, water immersion and anatomical notches on the mechanical properties of denture base resins reinforced with continuous high performance polyethylene fibers. Aust. dent. J., v. 37, n. 4, p. 277-89, Aug. 1992.

68 LADIZESKY, N. H.; CHOW, T. W; CHENG, Y. Y. Denture base reinforcement using woven polyethylene fiber. Int. J. Prosthodont., v. 7, n. 4, p. 307-14, July/Aug. 1994.

69 LADIZESKY, N. H. et al. Acrylic resin reinforced with chopped high performance polyethylene fiber - properties and denture construction. Dent. Mat., v. 9, n. 2 , p. 128-35, Mar. 1993.

70 LIBMAN, W. J.; NICHOLLS, J. I. Load fatigue of teeth restored with cast posts and cores and complete crowns. Int. J. Prosthodont., v. 8, n. 2, p. 155-61, Mar./Apr. 1995.

71 LOURENÇO, A. L. B. et al. Restauração biológica posterior - relato de caso clínico. Âmbito Odont., v. 6, n. 26, p. 5-8, nov./dez. 1995.

72 LUI, J. L. A technique to reinforce weakned roots with post canals. Endod. dent. Traumat., v. 3, n. 6, p. 310-4, Dec. 1987.

73 LUI, J. L. Composite resin reinforcement of flared canals using lighttransmitting plastic posts. Quintessence Int., v. 25, n. 5, p. 313-9, May 1994.

74 MADER, C. Restoration of a fractured anterior tooth. J. Amer. dent. Ass., v. 96, n. 1, p. 113-5, Jan. 1978. 
75 MALQUARTI, G.; BERRUET, R. G.; BOIS, D. Prosthetic use of carbon fiber reinforced epoxy resin for esthetic crowns and fixed partial dentures. J. prosth. Dent., v. 63, n. 3, p. 251-7, Mar. 1990.

76 MANNOCCI, F., FERRARI, M., WATSON, T. F. Intermittent loading of teeth restored using quartz fiber, carbon-quartz fiber, and zirconium dioxide ceramic root canal posts. J. Adhes. Dent., v. 1, n. 2, p. 153-8, Summer 1999.

77 MANNOCCI, F. et al. Carbon fiber posts: clinical and laboratory studies. In: INTERNATIONAL SYMPOSIUM S. MARGHERITA LIGURE, 2., S. Margherita Ligury, 1998. Proceedings. S. Margherita Ligury, Italy, Hypocrates Edizioni, 1998, p. 17-21.

78 MARCHI, G. M. Resistência à fratura de raízes debilitadas reconstruídas morfologicamente com sistema adesivo associado a pinos intraradiculares. Piracicaba, 1997. 104 p. Dissertação (Mestrado) Faculdade de Odontologia de Piracicaba, Universidade de Campinas.

79 MARKLEY, M. R. Pin reinforcement and retention of amalgam foundations and restorations. J. Amer. dent. Ass., v. 56, n. 5, p. 675-9, May 1958.

80 MARTINEZ-INSUA, A. et al. Comparison of the fracture resistances of pulpless teeth restored with a cast post and core or carbon-fiber post with a composite core. J. prosth. Dent., v. 80, n. 5, p.527-32, Nov. 1998.

81 MATTISON, G. D. Photoelastic stress analysis of cast-gold endodontic posts. J. prosth. Dent., v. 48, n. 4, p. 407-11, Oct. 1982.

82 MILLER, T. E. A new material for periodontal splinting and orthodontic retention. Comp. Continuing Educ. Dent., v. 19, n. 6, p. 800-12, July 1993.

83 MILOT, P.; STEIN, S. Root fracture in endodontically treated teeth related to post selection and crown design. J. prosth. Dent., v. 68, n. 3, p. 428-35, Sept. 1992.

84 MONDELLI, J. Técnicas restauradoras para dentes com tratamento endodôntico. Rev. dent. Rest., v. 1, n. 3, p. 97-158, jul./set. 1998.

85 MONTEnegro, J. R. Questões do dia-a-dia. Rev. Ass. paul. cirurg. Dent., v. 52, n. 2, p. 157, mar./abr. 1998. 
MORGANO, S. M.; BRACKETT, S. Foundations restorations in fixed prosthodontics: current knowledge an future reeds. J. prosth. Dent., v. 82, n.6, p. 643-57, Dez. 1999.

MOSCOVICH, H. C.; CREUGERS, H. J. The novel use of extracted teeth as a dental restorative material - the "Natural Inlay". J. dent., v. 26, n. 1, p. 21-4, Jan. 1998.

88 O'KEEFE, K. L.; MILLER, B. H.; POWERS, J. M. In vitro tensile bond strenght of adhesive cements to new post materials. Int. J. Prosthodont., v. 13, n. 1, p. 47-51, Jan./Feb. 2000.

89 OTTL, P. et al. Fracture characteristics of carbon fiber, ceramic an nonpalladium endodontic post systems at monotonously increasing loads. J. oral Rehab., v. 29, n. 2, p. 175-83, Feb. 2002.

90 PEREIRA, G. D. S.; SOUZA, G. M. D.; PAUlillo, L. A. M. S. Recuperação estética por meio de fibras de polietileno. Rev. bras. Odont., v. 56, n. 4, p. 160-4, jul./ago. 1999.

91 POZZOBON, R. T.; BANDEIRA, M. F. C.; CASTRO, S. L. "Overlay natural": uma opção restauradora através da colagem de fragmento dental. J. bras. Odont. Clín., v. 4, n. 19, p. 63-8, jan./fev. 2000.

92 PURTON, D. G., LOVE, R. M. Rigidity and retention of carbon fiber versus stainless steel root canal posts. Int. Endod. J., v. 29, n. 1, p. 262-5, July 1996.

93 RABIE, G. et al. Stregthening and restoration of immature teeth with an acidetch resin technique. Endod. dent. Traumat., v. 1, n. 6, p. 246-56, Dec. 1985.

94 RAMIRES-ROMITO, A. C. D. et al. Biologic restoration of primary anterior teeth. Quintessence Int., v. 31, n. 6, p. 405-11, June 2000.

95 RAMOS JÚNIOR, V.; RUNYAN, D. A.; CHRISTENSEN, L. C. The effect of plasma-treated polyethylene fiber on the fracture strength of polymethyl metacrylate. J. prosth. Dent., v. 76, n. 1, p. 94-6, July 1996.

96 RATH, I. B. S.; GLAVAM, P. R. C.; SILVA, R. H. H. Colagem heterógena de primeiro molar permanente. Rev. gaúcha Odont., v. 42, n. 3, p. 155-8, maio/jun. 1994. 
97 RAYGOT, C. G.; CHAI, J.; JAMESON, L. Fracture resistance and primary failure mode of endodontically treated teeth restored with a carbon fiberreinforced resin post system in vitro. Int. J. Prosthodont., v. 14, n.2, p. 141-5, mar./apr. 2001.

98 RING, M. E. História ilustrada de la odontologia. Barcelona, Doyma, 1989.

99 ROVATTI, L.; MASON, P. N.; DALLARI, A. New researches on fibre carbon posts. Minerva Stomatologica, v. 43, n. 12, p. 17-20, Dic. 1994.

100 ROVATTI, L., MASON, P. N., DALLARI, A. The esthetical endondontic posts. In: INTERNATIONAL SYMPOSIUM S. MARGHERITA LIGURE, 2., S. Margherita Ligury, 1998. Proceedings. S. Margherita Ligury, Italy, Hypocrates Edizioni, 1998, p. 12-6.

101 RUDO, D. N.; KARBHARI, M. E Physical behaviors of fiber reinforcement as applied to tooth stabilization. Dent. Clin. N. Amer., v. 43, n. 1, p. 735, Jan. 1999.

102 SAMADZADEH, A. et al. Fracture strengths of provisional restorations reinforced with plasma-treated woven polyethylene fiber. J. prosth. Dent., v. 78, n.5, p. 447-50, Nov. 1997.

103 SANTOS-PINTO, L. et al. Reabilitação oral anterior - alternativas de tratamento em Odontopediatria. J. bras. Odontopediat. Odont. Bebê, v. 4, n. 19, p. 216-20, maio/jun. 2001.

104 SAUPE, W. A.; GLUSKIN, A. H.; RADKE, R. A. A comparative study of fracture resistance between morphologic dowel and cores and a resinreinforced dowel system in the intraradicular restoration of structurally compromised roots. Quintessence Int., v. 27, n. 7, p. 483-91, July 1996.

105 Shillingburg, H. T., KeSSLER, J. C. Príncipios da restauração dos dentes tratados endodonticamente. In: __ Restaurações protéticas dos dentes tratados endodonticamente. 2.ed. São Paulo, Quintessence, 1991. Cap. 1, p. 13-44.

106 SIDOLI, G. E., KING, P. A., SETCHELL, D. J. An in vitro evaluation of a carbon fiber-based post core system. J. prosth. Dent., v. 78, n. 1, p. 5-9, July 1997. 
107 SILVA E SOUZA JÚNIOR., M. H. et al. Reconstrução de dentes tratados endodonticamente. In: Odontologia estética: fundamentos e aplicações clínicas. Restaurações indiretas sem metal: resinas compostas e cerâmica. São Paulo, Ed. Santos, 2001. Cap. 4, p. 29-46.

108 SILVA FILHO, F. P. M.; ESBERARD, R. M. Restaurações de dentes anteriores fraturados com aproveitamento de fragmentos. Rev. gaúcha Odont., v. 30, n. 2, p. 99-103, abr./jun. 1982.

109 SILVERSTEIN, W. H. The reinforcement of weakened pulpless teeth. J. prosth. Dent., v. 14, n. 2, p. 372-81, Mar./Apr. 1964.

110 SIMONSEN, R. J. Traumatic fracture restoration: an alternative use of the acid etch technique. Quintessence Int., v. 10, n. 2, p. 15-21, Feb. 1979.

111 SIMONSEN, R. J. Restoration of a fractured central incisor using original tooth fragment. J. Amer. de nt. Ass., v. 105, n. 4, p. 646-8, Oct. 1982.

112 SIRIMAI, S.; RIIS, D. N.; MORGANO, S. M. An in vitro study of the fracture resistance and the incidence of vertical root fracture of pulpless teeth restored with six post-and-core systems. J. prosth. Dent., v.81, n.3, p. 262-9, Mar. 1999.

113 SOARES, J. C. F. Resistência à fratura de raízes enfraquecidas reconstruídas com sistemas restauradores adesivos. Bauru, 1999. $101 \mathrm{p}$. Dissertação (Mestrado) - Faculdade de Odontologia de Bauru, Universidade de São Paulo.

114 SORENSEN, J. A.; ENGELMAN, M. J. Effect of post adaptation on fracture resistance of endodontically treated teeth. J. prosth. Dent., v. 64, n. 4, p. 419-24, Oct. 1990.

115 SORENSEN, J. A.; ENGELMAN, M. J. Ferrule design and fracture resistance of endodontically treated teeth. J. prosth. Dent., v. 63, n. 5, p. 529-36, May 1990.

116 SORENSEN, J. A.; MARTINOFF, J. T. Clinically significant factors in dowel design. J. Prosth. Dent., v. 52, n.1, p.28-35, July 1984.

117 SORENSEN, J. A.; MARTINOFF, J. T. Intracoronal reinforcement and coronal coverage: a study of endodontically treated teeth. J. prosth. Dent., v. 51, n. 6, p. 780-4, June 1984. 
118 SORNKUL; E.; STANNARD, J. G. Strength of roots before and after endodontic treatment and restoration. J. Endod., v. 18, n. 9, p. 440-3, Sept. 1992.

119 STANDLEE, J. P. et al. Analysis of stress distribution by endododontic posts. Oral Surg., v. 33, n. 6, p.52-60, June 1972.

120 STEWARDSON, D. A. Non-metal post systems. Dent. Update, v. 28, n. 7, p. 326-36, Sept. 2001.

121 STRUB, J.R.; PONTIUS, O.; KOUTAYAS, S. Survival rate and fracture strength of incisors restored with different post and core systems after exposure in the artificial mouth. J. oral Rehab., v. 28, n. 2, p. 120-4, Feb. 2001.

122 TANER, B. et al. A study on impact and tensile strength of acrylic resin filled with short ultra-high molecular weight polyethylene fibers. J. oral Science, v. 41, n. 1, p. 15-8, Mar. 1999.

123 TERRY, D. A.; TRIOLO, P. T. Fabrication of direct fiber-reinforced posts: a structural design concept. J. esthet. Restor. Dent., v. 13, n.4, p. 228-40, July 2001.

124 TJAN, A. H. L.; WHANG, S. B. Resistance to root fracture of dowel channels with various thickness of buccal dentin walls. J. prosth. Dent., v. 53, n. 4, p. 496-500, Apr.1985.

125 TRABERT, K. C.; CAPUTO, A. A.; ABOU-RASS, M. Tooth fracture: a comparison of endodontic and restorative treatments. J. Endod., v. 4, n. 11, p. 341-5, Nov. 1978.

126 TROPE, M.; RAY, H. L. Resistance to fracture of endodontically treated roots. Oral Surg., v. 73, n. 1, p. 99-102, Jan. 1992.

127 TROPE, M.; MALTZ, D.O.; TRONSTAD, L. Resistance to fracture of restored endodontically treated teeth. Endod. dent. Traumat., v. 1, n. 3, p. 108-11, June 1985.

128 VILLA, G. E. P.; ANDREOLLI, M. F. Análise de custos dos procedimentos clínicos e laboratoriais de oito opções para recuperação estética e funcional da coroa de um incisivo central superior. Rev. Odont. UNICID, v. 8, n. 2, p. 103-7, jul./dez. 1996. 
129 WANDERLEY, M. T.; TRINDADE, C. P.; CORREA; M. S. N. P. Recursos práticos em odontopediatria. In: CORREA, M. S. N. P. Odontopediatria na primeira infância. São Paulo, Ed. Santos, 1998. Cap. 35, p. 505.

130 WILLIAMSON, D. L. et al. Effect of polyethylene fiber reinforcement on the strength of denture base resins polymerized by microwave energy. J. prosth. Dent., v. 72, n. 6, p. 635-8, Dec. 1994.

131 WILSON, A. D.; KENT, B. E. A new translucent cement for dentistry: the glass ionomer cement. Brit. dent. J., v. 132, n. 15, p. 133-5, Feb. 1972.

132 YOUSSEF, M. N.; FICHMAN, D. M. Colagem de dentes naturais posteriores em dentes tratados endodonticamente. Rev. paul. Odont., v. 4, n.2, p. 43-5, mar./abr. 1992.

133 XIBLE, A. A. Avaliação da resistência ao cisalhamento de três sistemas de núcleos intra-radiculares. Bauru, 2000. 92 p. Dissertação (Mestrado) Faculdade de Odontologia de Bauru, Universidade de São Paulo.

134 ZANUTTO, J. R. et al. Reconstrução biológica da coroa dental. Rev. gaúcha Odont., v. 47, n. 2, p. 92-4, abr./jun. 1999. 
ABSTRACT 


\section{ABSTRACT \\ Evaluation of Fracture Resistance of Endodontically Treated Teeth Reconstructed with Dentinal Post and Cores and Polyethylene Woven Fiber Ribbon Post and Cores}

Fracture resistance of endodontically treated teeth reconstructed with polyethylene woven fiber ribbon post and cores and dentinal post and cores has been evaluated. For that purpose, 60 human maxillary canines were selected, cut on the cementoenamel junction, endodontically treated (non-filled canal to a depth of $8 \mathrm{~mm}$ ) and fixed in acrylic resin blocks. The specimens were randomly distributed in 4 groups of 15 units each: 1) conventional canal preparation and making of polyethylene woven fiber ribbon post and cores; 2) conventional preparation of canals and dentinal post and cores; 3 ) fairly flared canals and dentinal post and cores; 4) greatly flared canals and dentinal post and cores. On groups 1 and 2, canals were enlarged as much as number 4 Largo bur; on groups 3 and 4, canals were subjected to standardized sequential cutting to permit a simulation of fairly or greatly flared roots. On group 4 , the width of canal walls on the gingival third was $0.5 \mathrm{~mm}$. Post cementation was performed with the use of Scotchbond Multi-Purpose Plus bonding agent and Enforce resin cement. The core was built with self-curing composite reinforced with Ti-Core titanium. Specimens were stored in distilled water for 24 hours and subsequently subjected to compression fracture esistance tests on the Kratos universal testing machine until system failure. Load of $100 \mathrm{kgf}$ was applied at a speed of $0.5 \mathrm{~mm} / \mathrm{min}$ at an $135^{\circ}$ angle in relation to the long axis of the root. Fracture resistance under compression presented the following values (in decreasing order): 1) group 3 - 58.67kgf; 2) group 2 - 53.30kgf; 3) group 4 - 47.91kgf; 4) group 1 - 45.46kgf. Results were subjected to statistical analysis (ANOVA and Tukey), which only showed significant statistical difference between groups 1 and 3. As to the patterns of failure, the figures observed were: group $1-86.6 \%$ on the post and/or core; group $2-46.6 \%$ on the gingival third of the root and an equal figure for post and/or core; group $3-40 \%$ on the gingival third of the root and $53.3 \%$ on the post and/or core; group $4-66 \%$ on the gingival third of the root and $33.3 \%$ on the middle third of the root. 
APÊNDICE 


\section{FACULDADE DE ODONTOLOGIA DE BAURU}

COMTTÊ DE ÉTICA EM PESQUiSA

Bauru, 27 de abril de 2001

nmo. Sr.

Prof. Dr. Gerson Bonfente

FOB USP

Senhor Professor.

O projeto de pesquisa denominado "Avaliação da resistência à fratura de dentes tratados endodonticamente restaurados com quatro sistemas de núcleos" de autoria do C.D. Oswaldo Bazzan Keiser e que será desenvolvido sob sua orientaçá, foi recebido por este Comite e encaminhado ao relator para avaliação quanto aos seus aspectos 6́ticos.

O parecer do relator, aprovando o projeto, foi aceito pelo Comité de Ética em Pesquisa desta Faculdade na reuniao do dia 26 de abril de 2001.

Atenciosamente

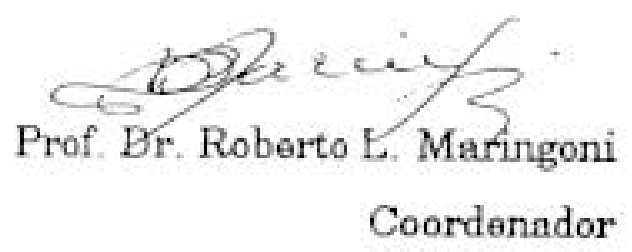

